UNIVERSIDADE DE SÃO PAULO

FACULDADE DE ZOOTECNIA E ENGENHARIA DE ALIMENTOS

GISELE DELA RICCI

Efeitos da climatização ambiental no comportamento e bem-estar de matrizes e leitões em maternidades livres de gaiolas 
Efeitos da climatização ambiental no comportamento e bem-estar de matrizes e leitões em maternidades livres de gaiolas

\author{
"Versão Corrigida"
}

Tese apresentada a Faculdade de Zootecnia e Engenharia de Alimentos da Universidade de São Paulo, como parte dos requisitos para a obtenção do título de Doutor em Ciências do programa de pós-graduação em Zootecnia.

Área de Concentração: Qualidade e Produtividade Animal

Orientadora: Profa. Dra. Cristiane Gonçalves Titto

Coorientadora: Profa. Dra. Késia Oliveira da Silva Miranda 
Ficha catalográfica elaborada pelo

Serviço de Biblioteca e Informaçäo, FZEAMUSP.

com os dados fornecidos pelo(a) autor(a)

Dela Ricci, Giaele

Bfeitoa da climatizaçăo ambiental no

DD331a

Bfeitoa da climatizaça ambiental no maternidadea livrea de gaiolan / Gisele Dela Ricci ; orientadora Criatiane Gonçalven Titto

coorientadora Kénia Oliveira da Silva Miranda. -. Pirasaununga, 2018.

$94 \mathrm{f}$.

Teae (Doutorado - Programs de P6e-Graduaçio em Zootecnia) -. Paculdade de Zootecnia e Bngenharis de Alimentos, Univeraidade de Săo Paulo.

1. Bem-eatar animal. 2. Suinocultura. 3.

Btologia. 4. Bioclimatologia. 5. Manejo racional.

I. Gonçalven Titto, Cristiane, orient. II. Oliveira

da Silva Miranda, Kéaia, coorient. III. Título.

Dermitida a obpia total ou pare1al desta documento, dande que c1tada a tonte - o autor 


\section{Efeitos da climatização ambiental no comportamento e bem-estar de matrizes e leitões em maternidades livres de gaiolas}

Tese apresentada a Faculdade de Zootecnia e Engenharia de Alimentos da Universidade de São Paulo, como parte dos requisitos para a obtenção do título de Doutor em Ciências do Programa de Pós-graduação em Zootecnia.

Área de Concentração: Qualidade e

Produtividade Animal

Data de aprovação: 19/10/2018

Profa. Dra. Cristiane Gonçalves Titto

Faculdade de Zootecnia e Engenharia de Alimentos/ USP

Dra Carolina Cardoso Nagib do Nascimento

Faculdade de Medicina Veterinária e Zootecnia/UNESP

Prof. Dr. José Roberto Sartori

Faculdade de Medicina Veterinária e Zootecnia/UNESP

Profa Dra Luciane Silva Martello

Faculdade de Zootecnia e Engenharia de Alimentos/ USP

Prof. Dr. Lúcio Francelino Araújo

Faculdade de Zootecnia e Engenharia de Alimentos/ USP

Prof. Dr. Rafael Teixeira de Sousa

Instituto de Educação, Ciência e Tecnologia do Ceará/ IFC 


\section{DEDICATÓRIA}

À Deus que tudo pode e nos dá razões a todo amanhecer para continuar.

Ao meu pai, Luiz Carlos, que buscou forças para que eu alcançasse meus sonhos com muita honestidade, zelo, hombridade e felicidade. Que independente da maneira, ensinou que não há outro caminho para o sucesso se não o trabalho árduo e a honestidade dos passos. Que mesmo em saudade me ensinou, com seu exemplo, a ser forte, superar medos e vencer batalhas porque delas tiraremos a felicidade diária. Agradeço com muito carinho.

Ao meu namorado, Norberto, pela honestidade, compreensão, força de vontade, felicidade, amor e paciência neste anos que, com certeza, me motivaram, incentivaram e fizeram com que tudo fosse possível. Sem a fortaleza ao meu lado, tudo teria sido mais difícil.

À minha orientadora Professora Cristiane Gonçalves Titto, pelo profissionalismo impecável. Justa, honesta, inteligente e paciente. Muito obrigada pela convivência e por compartilhar seu conhecimento, contribuindo para meu crescimento científico e intelectual. Você será sempre meu exemplo pessoal e profissional.

À minha família, a minha mãe, Maria do Rosário, pelo esforço desmedido para que eu pudesse chegar até aqui. Aos meus tios Djair, Luzia, Neuza, Aloizio, Dalva e César pelo apoio e carinho durante a fase mais difícil, que na ausência do meu pai, uniram-se ao meu sonho para que eu pudesse torna-lo realidade, obrigada. Obrigada especial ao meu tio Mario, que mesmo em memória, está presente neste estudo, pelas opiniões que prestou, pelos conselhos e pela presença em minha vida, todos esses anos. Um eterno obrigada.

Aos meus amigos Elder, Luiz Henrique, Paula, Rafael, Emerson e Marcela pela fidelidade, lealdade, companheirismo, carinho e por tornar todo esse tempo mais leve e feliz.

Ao Professor Dr. Evaldo Lencioni Titto pelas palavras certas, nas horas certas. Momentos inesquecíveis, de muito respeito e exemplo pessoal que se perpetuaram.

À professora Dra. Késia pela oportunidade e amizade.

À Faculdade de Zootecnia e Engenharia de Alimentos pela oportunidade de realização do curso de doutorado, pelas aulas e por todas as atividades complementares.

Agradeço aos animais que foram utilizados neste estudo aos quais tenho muito respeito e gratidão.

À CAPES pela concessão da bolsa de doutorado e apoio financeiro para a realização desta pesquisa.

Aos membros do Laboratório de Biometeorologia e Etologia (LABE), em especial a Dra Thays e estagiários pela assistência e colaboração.

Dedico. 


\section{RESUMO}

DELA RICCI, G. Efeitos da climatização ambiental no comportamento e bem-estar de matrizes e leitões em maternidades livres de gaiolas. 2018. 94f. Tese (Doutorado)Faculdade de Zootecnia e Engenharia de Alimentos, Universidade de São Paulo, 2018.

Suínos se adaptam às adversidades ambientais impostas pelo confinamento à partir de alterações fisiológicas e comportamentais e a inserção de climatizações simples podem melhorar o conforto e o bem-estar dos animais. O objetivo deste estudo foi avaliar os efeitos da climatização ambiental da maternidade livre de gaiolas, no comportamento e bem-estar de matrizes e leitões. Foram utilizadas 26 fêmeas e 281 leitões da linhagem Large White $x$ Landrace, desmamados aos 21 dias, mantidos em dois tipos de ambiente: climatizado (ventilador e aspersor em telhado) e não climatizado (controle), no setor de suinocultura da Prefeitura do campus Fernando Costa, da USP, em Pirassununga. A temperatura interna no ambiente controle às 7 horas foi de $23,7^{\circ} \mathrm{C} \pm 0,64$ com umidade de $74 \% \pm 1,64$ e às 13 horas de $26,2^{\circ} \mathrm{C} \pm 1,23 \mathrm{com}$ umidade de $70,4 \% \pm 1,68$. No ambiente climatizado, às 7 horas a temperatura ambiental encontrada foi de $22,1^{\circ} \mathrm{C} \pm 0,66 \mathrm{C}$ com umidade de $81,9 \% \pm 1,66$ e às 13 horas $24,5^{\circ} \mathrm{C} \pm 0,85$ e umidade de $85,7 \% \pm 1,34$. A frequência respiratória e a temperatura retal foram obtidas três vezes por semana, duas vezes ao dia, de manhã e à tarde, por contagem do flanco por minuto e termômetro retal digital, respectivamente. As colheitas de saliva para análise de cortisol (apenas matrizes) foram realizadas uma vez por semana, duas vezes ao dia, de manhã e à tarde. A avaliação da hierarquia de dominância e os registros da escolha das tetas foram realizados em três análises por semana a partir de observações focais diretas, sendo duas por período, de manhã e à tarde. A classificação em leitões dominantes, intermediários e subordinados foi obtida por porca, de acordo com a apresentação de brigas entre leitões. Para análise estatística da hierarquia foi construída uma matriz binária de dominância baseada nas ocorrências das brigas, identificando os indivíduos das linhas que dominam indivíduos das colunas, analisados por meio de variância com efeitos fixos de tratamento, períodos, sexo e suas interações. O comportamento e a preferência ambiental foram obtidos três vezes por semana, duas vezes ao dia, duas horas por período, de manhã e à tarde. Os locais avaliados foram esquerdo (lado com bebedouros), direito (barra antiesmagamento), meio (cama e enriquecimento), frente (piso de concreto) e atrás (cama de bagaço de cana). As medidas de comportamento e preferência ambiental foram avaliadas por análise de variância, com efeitos de tratamento, hora e local. As temperaturas superficiais dorsais, ventrais, das patas, pernis, cabeças, focinhos, oculares e de glândula mamária (porcas) foram medidas utilizando câmera termográfica de infravermelho, além das temperaturas do telhado, da cama e do piso. A temperatura do ar, umidade relativa e a temperatura do globo negro também foram obtidas e armazenadas em datalogger e foram 
realizadas correlações entre os dados ambientais e de temperatura superficial. As imagens termográficas foram analisadas pelo software IRSoft Version 3.6 Testo e analisadas por variância com efeitos fixos de tratamento e estação do ano. Os resultados mostraram que em relação à hierarquia não houve efeito dos fatores fixos $(P>0,05)$. Os leitões procuraram com maior frequência as tetas intermediárias, superiores e inferiores. O sexo não influenciou na classificação de hierarquia. Leitões classificados como leves apresentaram menor ganho de peso ao desmame no ambiente climatizado. Em relação ao comportamento, não houve interação entre os períodos e os locais para as porcas e leitões. As fêmeas preferiram o lado esquerdo, seguido pelo direito, na frente, atrás e no meio da baia. O peso ao desmame e a perda de peso das fêmeas não apresentaram efeito dos ambientes $(P>0,05)$. Em relação às análises de termografia de infravermelho, as estações do ano influenciaram as temperaturas da cama, do concreto e telhado, devido as maiores temperaturas encontradas no verão. Foram encontradas correlações positivas em relação a temperatura interna das instalações para cama $(r=0,28 ; P<0,05)$ e concreto $(r=0,26 ; P<0,05)$. Para as fêmeas, as estações do ano influenciaram as temperaturas corporais. Foram encontradas correlações positivas em relação a cama e as temperaturas do dorso, ventre, glândula mamária, pernil, cabeça e olhos. A frequência respiratória apresentou correlação positiva com o dorso, focinho, cama, concreto e telhado. O cortisol salivar não apresentou correlações positivas e significativa com as instalações. As estações do ano e os períodos do dia influenciaram as temperaturas superficiais dos leitões, com maiores temperaturas no verão e no período da tarde. A frequência respiratória teve influência do período do dia com maiores frequências apresentadas à tarde. Conclui-se com este estudo que a climatização não influencia na escolha das tetas na glândula mamária. A climatização ambiental gerou maior conforto térmico às matrizes, no entanto, não alterou o conforto de leitões, uma vez que estes possuíam escamoteadores com a função de proteger contra temperaturas abaixo da sua zona de conforto térmico. A presença de ventiladores e aspersores de água no telhado não foi suficiente para reduzir a temperatura superficial corporal de fêmeas e leitões inseridos em baias livres de gaiolas em fase de maternidade.

Palavras chave: Etologia. Hierarquia. Preferência. Procedimentos. Termografia. Vocalização. 
DELA RICCI, G. et al. Effects of environmental climatization on the behavior and welfare of sows and piglets in cage-free maternity. 2018. 94f. Thesis (Doctoral) - Faculdade de Zootecnia e Engenharia de Alimentos, Universidade de São Paulo, 2018.

Pigs adapt to the environmental adversities imposed by confinement from physiological and behavioral changes and the insertion of simple climatizations can improve the comfort and well-being of the animals. The objective of this study was to evaluate the effects of environmental conditioning of cage-free motherhood on the behavior and well-being of sows and piglets. Twenty-six females and 281 piglets of the Large White $x$ Landrace strain, weaned at 21 days, were kept in two types of environment: climated (ventilator and sprinkler on roof) and non-climated (control) Costa, of the USP, in Pirassununga. The internal temperature in the control environment at 7 hours was $23.7^{\circ} \mathrm{C} \pm 0.64$ with humidity of $74 \% \pm 1.64$ and at 13 hours of $26.2^{\circ} \mathrm{C} \pm 1.23$ with humidity of $70.4 \% \pm 1.68$. In the air-conditioned environment, at 7 o'clock the ambient temperature was $22.1^{\circ} \mathrm{C} \pm 0.66 \mathrm{C}$ with humidity of $81.9 \% \pm 1.66$ and at 13 hours $24.5^{\circ} \mathrm{C} \pm 0.85$ and humidity of $85,7 \% \pm 1.34$. Respiratory rate and rectal temperature were obtained three times a week, twice a day, morning and afternoon, by counting the flank per minute and digital rectal thermometer, respectively. Saliva harvests for cortisol analysis (matrices only) were performed once a week, twice daily in the morning and afternoon. The evaluation of dominance hierarchy and teat selection records were performed in three analyzes per week from direct focal observations, two per period, morning and afternoon. Classification in dominant, intermediate and subordinate piglets was obtained by sow, according to the presentation of fights among piglets. For statistical analysis of the hierarchy, a binary matrix of dominance based on occurrences of fights was constructed, identifying the individuals of the lines dominating column individuals, analyzed by means of variance with fixed treatment effects, periods, sex and their interactions. Behavior and environmental preference were obtained three times per week, twice a day, two hours per period, morning and afternoon. The sites evaluated were left (side with drinking fountains), right (anti-crushing bar), middle (bed and enrichment), front (concrete floor) and behind (cane bagasse bed). The measures of behavior and environmental preference were evaluated by analysis of variance, with effects of treatment, time and place. Dorsal, ventral surface temperatures of the legs, legs, heads, muzzles, eyepieces and mammary gland (sows) were measured using infrared thermographic camera, as well as roof, bed and floor temperatures. The air temperature, relative humidity and black globe temperature were also obtained and stored in a datalogger and correlations were made between environmental and surface temperature data. The thermographic images were analyzed by the software IRSoft Version 
3.6 Testo and analyzed by variance with fixed effects of treatment and season of the year. The results showed that in relation to the hierarchy there was no effect of the fixed factors $(P>$ 0.05). The piglets sought more often the intermediate, upper and lower teats. Sex did not influence the classification of hierarchy. Piglets classified as lightweight presented lower weight gain at weaning in the air-conditioned environment. Regarding the behavior, there was no interaction between periods and sites for sows and piglets. The females preferred the left side, followed by the right, front, back and middle of the bay. Weaning weight and weight loss of the females had no effect of the environments $(P>0.05)$. Regarding infrared thermography analyzes, the seasons of the year influenced bed, concrete and roof temperatures due to the higher summer temperatures. Positive correlations were found regarding the internal temperature of bed facilities $(r=0.28, P<0.05)$ and concrete $(r=0.26, P<0.05)$. For females, the seasons influenced the body temperatures. Positive correlations were found regarding bed and temperatures of the back, belly, mammary gland, thigh, head and eyes. The respiratory rate showed a positive correlation with the back, snout, bed, concrete and roof. Salivary cortisol did not present positive and significant correlations with the facilities. The seasons and the periods of the day influenced the superficial temperatures of the piglets, with higher temperatures in the summer and in the afternoon. The respiratory rate was influenced by the period of the day with higher frequencies presented in the afternoon. It is concluded with this study that the climatization does not influence the choice of the tits in the mammary gland. The ambient climated generated greater thermal comfort to the matrices, however, did not alter the comfort of piglets, since they had escamoteadores with the function of protecting against temperatures below their zone of thermal comfort. The presence of ventilators and water sprinklers on the roof was not sufficient to reduce the body surface temperature of females and piglets inserted in stalls free of maternity cages.

Keywords: Ethology. Hierarchy. Preference. Procedures. Thermography. Vocalization. 


\section{LISTA DE ILUSTRAÇÕES}

Figura 1 - Classificação das tetas em superiores, medianas e inferiores em relação aos lados direito e esquerdo da glândula mamária.

Figura 2 - Demonstrativo da divisão da baia em áreas especificas para estudo de preferência ambiental pelas porcas .......................................................................... 38

Figura 3 - Demonstrativo das áreas corporais onde foram registrados imagens com a utilização da câmera termográfica em porcas e leitões. 57

Figura 4 - Demonstrativo das áreas da instalação da maternidade onde foram obtidos dados com a utilização da câmera termográfica. 


\section{LISTA DE TABELAS}

Tabela 1- Preferências pelos tetos na glândula mamária de porcas de acordo com a categoria

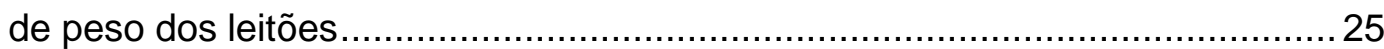

Tabela 2- Demonstrativo de leitões classificados como dominantes, intermediários e subordinados em relação ao sexo e a média de peso ao nascimento na competição pelas tetas na glândula mamária .................................................26

Tabela 3- Peso ao desmame em $\mathrm{kg}$ de acordo com as categorias definidas ao nascer diante dos ambientes avaliados

Tabela 4- Descrição do etograma de trabalho com a descrição dos comportamentos observados durante a realização da análise etológica

Tabela 5- Comportamentos apresentados por fêmeas suínas em relação aos períodos do dia e aos ambientes avaliados

Tabela 6- Comportamentos observados em leitões durante os períodos da manhã e da tarde e ambientes controle e climatizado

Tabela 7- Correlações entre temperaturas superficiais corporais de leitões mantidos em baias livres de gaiolas e temperatura superficial de estruturas das instalações obtidas com câmera termográfica

Tabela 8- Demonstrativo das médias de preferência ambiental geral pelas fêmeas em relação aos locais dentro das baias individuais livres de gaiolas.

Tabela 9- Preferência ambiental das fêmeas em relação aos períodos do dia e aos ambientes controle e climatizado

Tabela 10- Correlações entre temperaturas superficiais corporais de fêmeas mantidas em baias livres de gaiolas e temperatura superficial de estruturas das instalações obtidas com câmera termográfica.

Tabela 11- Temperaturas e umidades dos ambientes climatizado e controle de acordo com as estações do ano e horários de avaliação

Tabela 12- Temperaturas superficiais, em graus Celsius, dos pisos e telhado obtidas por meio da câmera termográfica das instalações da maternidade de baias livres de gaiolas seguidas dos erros padrões

Tabela 13- Temperaturas superficiais corporais, em graus Celsius, e seus erros padrões, obtidas a partir da câmera termográfica das fêmeas suínas em fase de maternidade

Tabela 14- Correlações entre temperaturas superficiais corporais de fêmeas mantidas em baias livres de gaiolas e temperatura superficial de estruturas das instalações obtidas com câmera termográfica

Tabela 15- Correlações entre parâmetros fisiológicos de fêmeas suínas e temperaturas superficiais de estruturas das instalações obtidas com câmera termográfica ....61

Tabela 16- Temperaturas superficiais corporais obtidas a partir da câmera termográfica de leitões em fase de maternidade mantidos em baias livres de gaiolas

Tabela 17- Correlações entre temperaturas superficiais corporais de leitões mantidos em baias livres de gaiolas e temperatura superficial de estruturas das instalações obtidas com câmera termográfica. 


\section{SUMÁRIO}

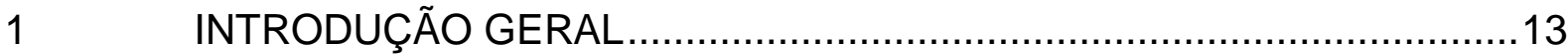

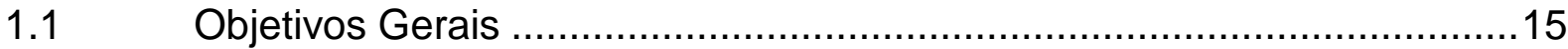

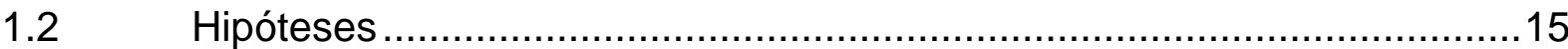

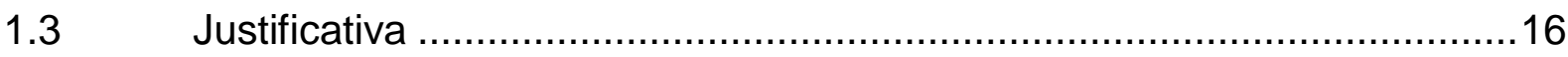

Referências............................................................................... 17

2 CLIMATIZAÇÃO AMBIENTAL E SUA INTERFERÊNCIA NA HIERARQUIA DE MAMADA E GANHO DE PESO DE LEITÕES EM FASE DE

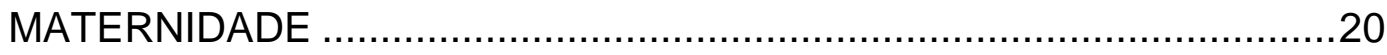

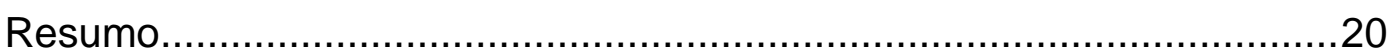

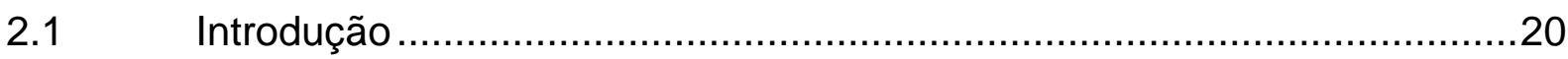

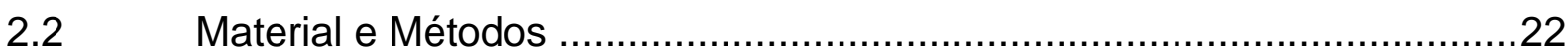

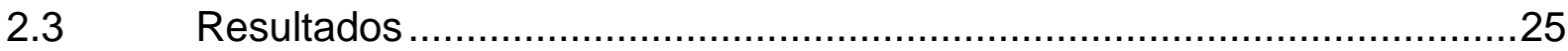

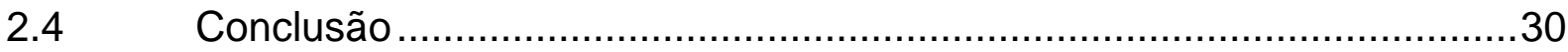

Referências........................................................................ 31

3 COMPORTAMENTO E PREFERÊNCIA AMBIENTAL DE SUÍNOS MANTIDOS EM MATERNIDADE CLIMATIZADA LIVRE DE GAIOLAS...34

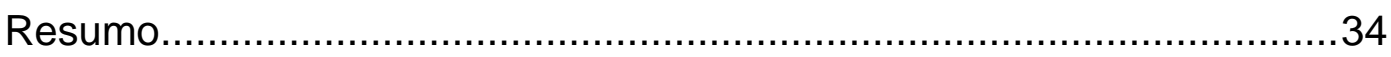

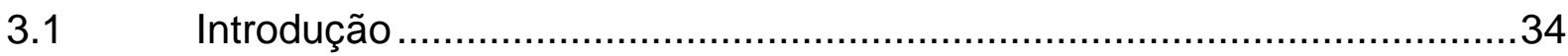

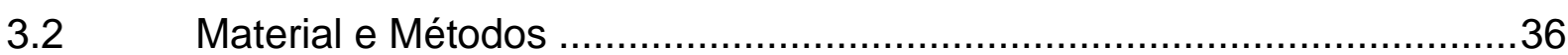

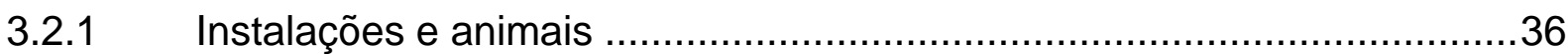

3.2.2 Análise etológica de leitões e porcas ...............................................37

3.2.3 Análise de preferência ambiental das porcas ......................................38

3.3 Resultados .......................................................................... 40

3.3.1 Comportamentos das fêmeas .................................................... 40

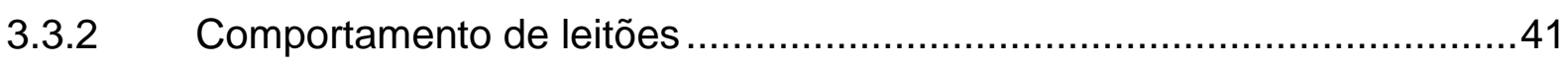

3.3.3 Preferência Ambiental............................................................... 43

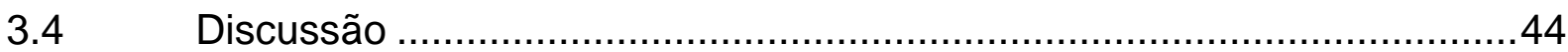

3.4.1 Análise Etológica ................................................................... 44

3.4.2 Preferência Ambiental..................................................................... 47

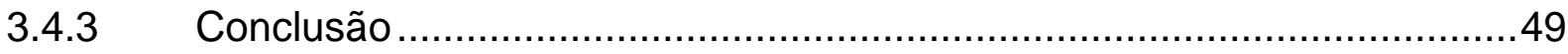

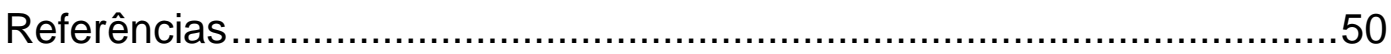

4 TERMOGRAFIA INFRAVERMELHA COMO MÉTODO NÃO INVASIVO PARA AVALIAÇÃO DE ESTRESSE POR CALOR EM SUÍNOS MANTIDOS EM BAIAS LIVRES DE GAIOLAS NA MATERNIDADE ........................53

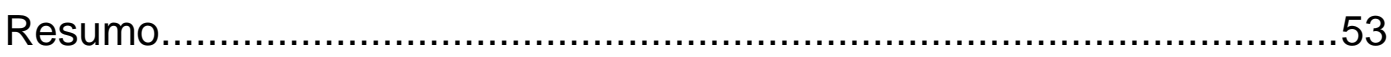

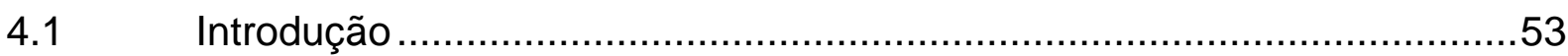

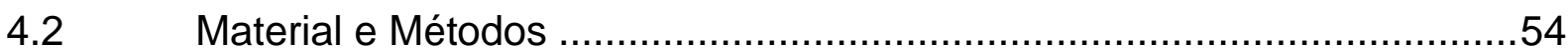




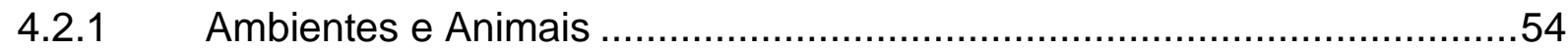

4.2.2 Análises fisiológicas de fêmeas suínas e leitões ...................................56

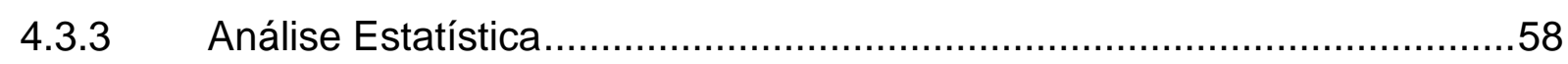

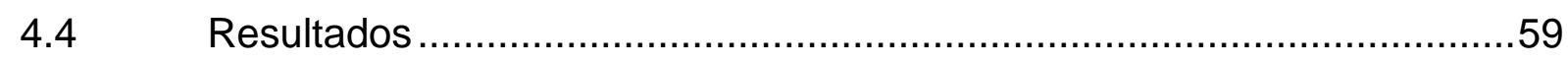

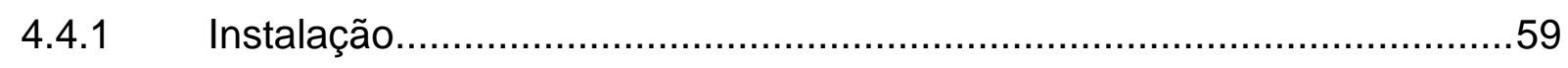

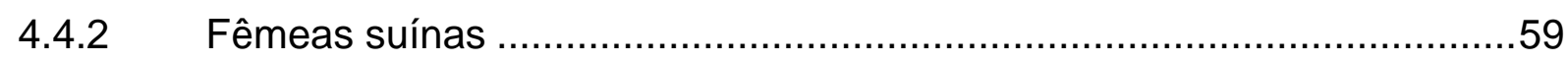

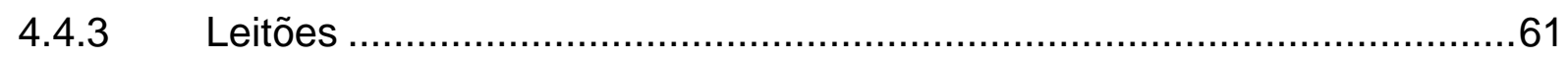

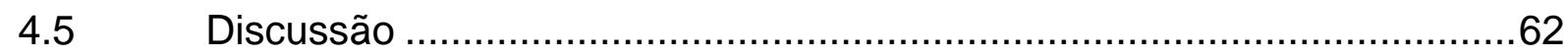

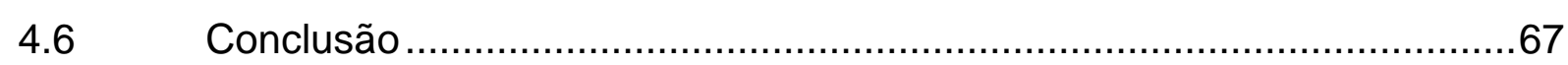

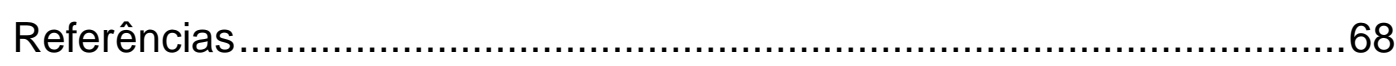

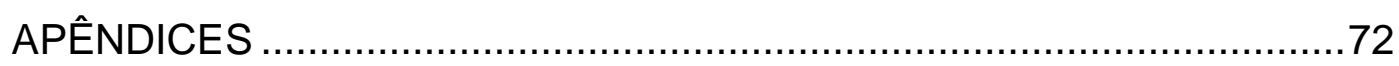




\section{INTRODUÇÃO GERAL}

A suinocultura é considerada uma das formas mais intensivas de criação animal, caracterizada pelo espaço restrito, em todas as fases, resultando em pouca movimentação e interação entre os animais, ocasionando alterações importantes no comportamento e conforto dos suínos (PUTTEN, 1989).

No entanto, avanços na genética, nutrição e manejo em conjunto com a pressão imposta aos produtores pelos consumidores por uma criação de animais ética, promoveram a adoção de práticas de produção animal com ênfase no bem-estar e em suas consequências para a produtividade (HARVEY; HUBBARD, 2013).

A análise do bem-estar animal pode ser realizada a partir de critérios ambientais, com avaliações do aumento dos níveis de ruídos (pressão sonora), da temperatura e umidade do ar; a partir de análises comportamentais, com a observação de estereotipias e por meio de mecanismos fisiológicos obtidos pelo aumento das concentrações de cortisol, da frequência cardíaca e respiratória, de respostas do sistema imunológico e da sanidade (BAPTISTA et al., 2011; BROOM; MOLENTO, 2004).

Dentre as variáveis ambientais, a temperatura do ar pode afetar a saúde, o bem-estar e a eficiência na produção intensiva de suínos, considerando essencial entender a resposta do animal confinado em relação ao ambiente térmico, a fim de minimizar os efeitos negativos do desconforto (BANHAZI et al., 2008).

O suíno adulto possui dificuldade para se adaptar ao calor uma vez que apresenta elevado metabolismo, limitantes perdas pela sudorese e capa de tecido adiposo subcutâneo espessa (RODRIGUES et al., 2010). As glândulas sudoríparas na superfície da pele são inativas devido à queratina, contribuindo pouco na termorregulação (ROBINSON, 2008).

Suínos expostos à temperaturas acima do limite da zona de conforto térmico utilizam a frequência respiratória, decorrente da estimulação do centro de calor no hipotálamo e do centro cardiorrespiratório como perda evaporativa (HABBED et al., 1992), sendo esta considerada mecanismo termoregulatório inadequado pelo seu gasto elevado de energia (CLOSE; MOUNT, 1978) e pela possibilidade de alcalose respiratória decorrente da hiperventilação (PENZ JR., 1991).

A frequência respiratória pode variar extrinsecamente em razão de fatores relacionados ao ambiente, como temperatura e umidade do ar, radiação solar, velocidade do vento, período do dia, sombreamento, estação do ano e densidade de alojamento dos suínos (PEREIRA, 2005), podendo ser alterada intrinsicamente em razão de respostas à excitações, como medo, exercícios físicos, estados fisiológicos e produção leiteira (BACCARI Jr., 2001).

Em conforto térmico os suínos apresentam valores de frequência respiratória para leitões ao nascimento de 40 a 50 movimentos por minuto, na lactação de 30 a 40 e no 
desmame de 25 a 40. Para fêmeas gestantes, a frequência é de 15 a 20 e para lactantes de 20 a 30 movimentos por minutos (MUIRHEAD; ALEXANDER, 1997; ROBERTSHAW, 2006; ROBINSON, 2008; SOUSA, 2004). Frequências acima de 40 movimentos por minuto já apontam estresse térmico, sendo que a frequência se eleva antes da temperatura retal (RODRIGUES et al., 2010).

A mensuração da temperatura retal pode ser considerada um indicador importante para diagnóstico de temperatura do núcleo corporal, para estimativa da condição de conforto, estresse por calor nos suínos além do grau de adaptabilidade dos animais aos ambientes, condições ou enfermidades (BROWN-BRANDL et al., 2003). Apresenta maior inercia nas alterações, obtendo equilíbrio de forma mais lenta que outras partes do corpo, sendo bom indicador do estado fisiológico do indivíduo (ROBERTSHAW, 2006; ROBINSON, 2008).

Em altas temperaturas suínos alteram seu comportamento (HUYNH et al., 2005), reduzindo sua atividade e buscando áreas úmidas. Modificações do ambiente de confinamento podem melhorar o bem-estar dos animais, satisfazendo suas necessidades comportamentais e fisiológicas (BRACKE et al., 2006). O uso de baias sem gaiolas para as matrizes auxilia na termorregulação, com a possibilidade de alteração da postura e escolha por áreas área mais confortáveis ao longo do dia.

Em estresse térmico, matrizes suínas apresentam estereotipias com movimentos repetidos, (JESEN, 2009), de forma compensatória e tranquilizante, que ocorrem por meio da redução da atividade do eixo pituitária-adrenal, com diminuições dos níveis de cortisol nos animais (DANTZER; MORMEDE, 1983). Os comportamentos mais observados descritos como estereotipias são a mastigação das instalações, como gaiolas, bebedouros, madeiras, comedouros além do enrolar da língua e a falsa mastigação (ZANELLA, 1995; POLETTO, 2010).

Em estresse por calor, o comportamento ingestivo sofre alterações devido a modificações na quantidade e tempo de ingestão de alimentos pelas matrizes suínas (QUINIOU et al., 2000), reduzindo o pico de consumo, modificando o hábito alimentar para as horas do dia com temperaturas mais amenas (GOURDINE et al., 2006).

Mudanças na postura e conduta materna, aliado ao comportamento ingestivo, são efeitos do estresse por calor, responsáveis pela redução do desempenho produtivo de matrizes suínas e seus leitões (QUINIOU; NOBLET, 1999; RENAUDEAU et al., 2003; RENAUDEAU; NOBLET, 2001).

Suínos são capazes de expressar comportamentos individuais diferentes para conseguir lidar com situações de estresse ou conflitos e utilizam a vocalização, método não invasivo de estimativa de bem-estar, para se expressar desde as primeiras semanas após seu nascimento (HESSING et al., 1993). Em situações de estresse, as vocalizações emitidas 
pelos suínos representam um indicador importante da bem-estar dos animais e se determina como uma análise instantânea do estado fisiológico dos suínos (DUPJAN et al., 2008).

As instalações do confinamento podem ser enriquecidas por meio de práticas simples, como a inserção de ventiladores e aspersores de água que tornam o ambiente fisicamente mais adequado para atender as características fisiológicas e comportamentais dos suínos. enriquecimento ambiental tem como objetivo reduzir estímulos que conduzam a respostas estressoras, tornando o ambiente mais adequado as necessidades comportamentais dos animais, reduzindo a incidência de comportamentos estereotipados (MENDONÇAFURTADO, 2006).

A inserção de ventiladores e aspersores de telhado são técnicas simples e práticas que proporcionam conforto aos suínos, mesmo em instalações que não atendam requisitos mínimos de conforto térmico para a espécie. Matrizes suínas apresentam preferência por ambientes constituídos por lâminas de água nos períodos mais quentes do dia e optam por locais secos e com cama nos períodos de temperatura mais amena demonstrando alternância de comportamento relacionada a temperatura ao longo do dia e da capacidade térmica das instalações em que estão inseridas.

Dela Ricci et al. (2018) avaliando o comportamento de fêmeas suínas de diferentes ordens de parto em fase de maternidade em ambientes enriquecidos com ventiladores e aspersores de água no verão concluíram que o enriquecimento ambiental físico traz benefícios importantes no bem-estar devido à redução de comportamentos negativos melhorando a bem-estar dos suínos.

Diante dos desafios encontrados pelos suínos no confinamento, o estudo do comportamento animal, a partir de testes específicos, torna-se uma ferramenta essencial para apontar adequações do sistema de criação por meio de características importantes das espécies (WAIBLINGER et al., 2006), avaliando de maneira rápida e prática o bem-estar dos animais (POLETTO, 2010) e possibilitando a mensuração do estado individual em relação a sua adaptação ao ambiente onde estão alojados (BROOM, 1991).

\subsection{Objetivos Gerais}

Avaliar o comportamento e o bem-estar de matrizes e leitões em instalações com e sem resfriamento ambiental livre de gaiolas.

\section{$1.2 \quad$ Hipóteses}

O resfriamento ambiental, a partir da inserção de ventiladores e aspersores de telhado, gera alterações na hierarquia de mamada dos leitões ao longo da fase de maternidade; 
Há maior ganho de peso de fêmeas e leitões em no ambiente térmico com resfriamento durante a fase de maternidade;

Demonstrar que há alterações negativas nos comportamentos de ócio, exploratórios, estereotipados, agonísticos, lúdicos, alimentação, bebida e eliminatórios, de fêmeas suínas e leitões em ambiente não resfriado em instalações com baias sem gaiolas;

Fêmeas suínas possuem preferências ambientais por locais mais frescos dentro das baias nos ambientes climatizados livres de gaiolas;

A temperatura superficial de fêmeas mantidas em baias individuais livre de gaiolas e suas leitegadas pode ser avaliada a partir do uso da câmera termográfica, buscando indicar métodos sustentáveis para melhoria do bem-estar dos suínos em fase de maternidade.

\subsection{Justificativa}

$\checkmark$ A climatização ambiental por meio de ventiladores e aspersores de telhado gera melhoria do conforto térmico de suínos;

$\checkmark$ Existem evidências de que a hierarquia imposta pelos leitões nos primeiros dias após o nascimento ocorre de acordo com o peso e sexo dos animais;

$\checkmark$ O comportamento é alterado frente a ambientes que não proporcionem conforto térmico e bem-estar como os constituídos por gaiolas de contenção;

$\checkmark$ O ganho de peso dos suínos na fase de maternidade pode ser alterado de acordo com a temperatura ambiente, dentro ou fora da sua zona de conforto térmico;

$\checkmark$ Alterações das temperaturas superficiais corporais de suínos e das instalações de confinamento são notadas a partir de climatizações ambientais simples e podem ser avaliadas com eficiência a partir da utilização de termografia infravermelha;

$\checkmark$ Estudos relacionados a imposição de hierarquia, o comportamento, preferência e alterações nas temperaturas superficiais em ambiente climatizado são escassos e essências para compreensão dos efeitos para melhoria da bem-estar de suínos destinados à produção de carne. 


\section{Referências}

BACCARI JÚNIOR, F. Manejo ambiental da vaca leiteira em climas quentes. Londrina: UEL, 2001.

BANHAZI, T.; AARNINK, A.; THUY, H. et al. Review of issues related to heat stress in intensively housed pigs. In: INTERNATIONAL LIVESTOCK ENVIRONMENT SYMPOSIUM, 8., 2008, Foz do Iguaçu. Proceedings... Foz do Iguaçu: ASABE, 2008. 1 CD-ROM.

BAPTISTA, R. I. A. A.; BERTANI, G. R.; BARBOSA, A. N. Indicadores do bem-estar em suínos- revisão bibliográfica. Ciência Rural, Santa Maria, v. 40, p. 1-8, 2011.

BROOM, D. M.; MOLENTO, C. F. M. Bem-estar animal: conceito e questões relacionadas. Archives of Veterinary Science, Curitiba, v. 9, p. 1-11, 2004.

BROWN-BRANDL, T. M. et al. A literature review of swine heat and moisture production. Transactions of the American Society of Agricultural and Biological Engineers, St. Joseph, v. 47, p. 259-270, 2004.

CHALOUPKOVÁ, H. et al. The effect of pre-weaning housing on the play andagonistic behaviour of domestic pigs. Applied Animal Behaviour Science, Amsterdam, v. 103, p. 2534, 2007.

CLOSE, W. H.; MOUNT, L. E. The effects of plane of nutrition and environmental temperature on the energy metabolism of the growing pig. 1. Heat loss and critical temperature. British Journal of Nutrition, Cambridge, v. 40, p. 413-421, 1978.

DALLA COSTA, O. A. et al. Aspectos econômicos e de bem-estar animal no manejo dos suínos da granja até o abate. In: SEMINÁRIO INTERNACIONAL DE AVES E SUÍNOS, 4., 2005, Florianópolis. Anais eletrônicos... Florianópolis, 2005. Disponível em: <https://www.agencia.cnptia.embrapa.br/recursos/publicacao_c7t41d7n_pre_abatelDWyUdT5iwKc.pdf>. Acesso em: 20 ago. 2018.

DANTZER, R.; MORMEDE, P. De-arousal properties of stereotyped behaviour: evidence from pituitary-adrenal correlates in pigs. Applied Animal Behaviour Science, Amsterdam, v. 10, p. 233-244, 1983.

DÜPJAN, S. et al. Differential vocal responses to physical and mental stressors in domestic pigs (Sus scrofa). Applied Animal Behaviour Science, Amsterdam, v. 114, p. 105-115, 2008.

FERNANDES, H. C. et al. Efeito do aquecimento e resfriamento de pisos no desempenho de matrizes e leitões. Revista Ceres, Viçosa, v. 58, p. 701-709, 2011.

GOURDINE, J. L. et al. Effects of season and breed on the feeding behavior of multiparous lactating sows in a tropical humid climate. Journal of Animal Science, Champaign, v. 84, p. 469-480, 2006.

HARVEY, D.; HUBBARD, C. Reconsidering the political economy of farm animal welfare: An anatomy of market failure. Food Policy, Kidlington, v. 38, p. 105-114, 2013.

HESSING, M. J. C. et al. Individual behavioural characteristics in pigs. Applied Animal Behaviour Science, Amsterdam, v. 37, p. 285-295, 1993. 
HUYNH, T. T. T. et al. Thermal behavior of growing pigs in response to high temperature and humidity. Applied Animal Behaviour Science, Amsterdam, v. 91, p.1-16, 2005.

JENSEN, P.; ALGERS, B. An ethogram of piglet vocalizations during suckling. Applied Animal Ethology, Edinburgo, v. 11, p. 237-48, 1984.

LIMA, A. L. et al. Resfriamento do piso da maternidade para porcas em lactação no verão. Revista Brasileira de Zootecnia, Viçosa, v. 40, p. 804-811, abr. 2011.

MENDONÇA-FURTADO, O. Uso de ferramentas e convivência social como enriquecimento ambiental para macacos-prego (Cebus apella) cativos. 2006. $64 \mathrm{f}$. Dissertação (Mestrado) - Instituto de Psicologia, Universidade de São Paulo, 2006.

MOLENTO, C. F. M. Bem-estar e produção animal: aspectos econômicos - Revisão. Archives of Veterinary Science, Curitiba, v. 10, p. 1-11, 2005.

MUIRHEAD, M. R.; ALEXANDER, T. J. L. Managing pig health and the treatment of disease. United Kingdom: 5M, 1997.

PENZ JR., A. M. Nutrição de reprodutores em época de calor. In: MINISIMPÓSIO DO COLÉGIO BRASILEIRO DE NUTRIÇÃO ANIMAL, 5., 1991, Campinas. Anais... Campinas, 1991. p. 1-5.

PEREIRA, M. L. Biodigestores: opção tecnológica para a redução dos impactos ambientais na suinocultura. São Paulo, 2005. Disponível em:

<https://www.embrapa.br/>. Acesso em: 20 ago. 2018.

POLETTO, R. Bem-estar animal. Suíno.com, Tangará, 5 abr. 2010. (Série especial bemestar animal por Rosangela Poletto). Disponível em: <http://tinyurl.com/4t6z4bk>. Acesso em: 03 jul. 2018.

PUTEN, G. V. The pig: model for discussing animal behavior and welfare. Applied Animal Behaviour Science, Amsterdam, v. 22, p. 115-28, 1989.

QUINIOU, N.; NOBLET, J. Influence of high ambient temperatures on performance of multiparous lactating sows. Journal of Animal Science, Cary, v. 77, p. 2124-2134, 1999.

RENAUDEAU, D.; NOBLET, J. Effects of exposure to high ambient temperature and dietary protein level on sow milk production and performance of piglets. Journal of Animal Science, Champaign, v. 79, p. 1540-1548, 2001.

RENAUDEAU, D.; ANAIS, C.; NOBLET, J. Effects of dietary ber on performance of multiparous lactating sows in tropical climate. Journal of Animal Science, Champaign, v. 81, p. 717-725, 2003.

RICCI, G. D. et al. Análise do comportamento de matrizes suínas lactantes com o uso de enriquecimento ambiental na maternidade. In: SEMINÁRIO DE PESQUISA E EXTENSÃO DA UNC - SIPEX, 2., 2012, Concórdia/SC. Anais... Concórdia/SC, 2012, p. 12-43.

ROBINSON, N. E. Termorregulação. In: CUNNINGHAM, J. G. Tratado de fisiologia veterinária. 4. ed. Rio de Janeiro: Elsevier, 2008.

ROBERTSHAW, D. Mechanisms for the control of respiratory evaporative heat loss in panting animals. Journal of Applied Physiology, Rockville, v. 101, p. 664-668, 2006. 
RODRIGUES, V. C. et al. correct enthalpy relationship as thermal comfort index for livestock. International Journal of Biometeorology, Heidelberg, v. 55, p. 455-459, 2010.

SABINO, L. A. et al. Comportamento suíno influenciado por dois modelos de maternidade. Revista Brasileira de Engenharia Agrícola e Ambiental, Campina Grande, v. 15, p. 1321 1327, 2011.

SARUBBI, J. et al. Utilização de energia elétrica em diferentes sistemas de aquecimento para leitões desmamados. Engenharia Agrícola, Jaboticabal, v. 30, n. 6, p. 1003-1011, 2010.

SOUSA, P. Conforto térmico e bem-estar na suinocultura. Lavras: UFLA, 2004.

TALLET, C. et al. Effects of neonatal castration on social behaviour, human-animal relationship and feeding activity in finishing pigs reared in a conventional or an enriched housing. Applied Animal Behaviour Science, Amsterdam, v. 145, p. 70-83, 2013.

ZANELLA, A. J. Indicadores fisiológicos e comportamentais do bem-estar animal. A Hora Veterinária, Porto Alegre, v. 14, p. 47-52, 1995.

WAGENBERG, A. V. et al. Effect of floor cooling on farrowing sow and litter performance: field experi - ment under dutch conditions. Transactions of the American Society of Agricultural and Biological Engineers, St. Joseph, v. 49, p. 1521-1527, 2006. 


\section{CLIMATIZAÇÃO AMBIENTAL E SUA INTERFERÊNCIA NA HIERARQUIA DE MAMADA E GANHO DE PESO DE LEITÕES EM FASE DE MATERNIDADE1}

\section{Resumo}

A hierarquia entre suínos ocorre nos primeiros dias após o nascimento e pode ser influenciada pela sequência em que os animais mamam nos tetos. Este estudo teve como objetivo avaliar se a climatização do ambiente causa alterações hierárquicas de mamada e de ganho de peso de leitões. O estudo foi conduzido em maternidade com baias individuais acrescidas por ventiladores e aspersores do telhado e sem climatização ambiental. Foram avaliadas 26 fêmeas e 281 leitões, linhagem Large White x Landrace, de segunda ordem de parto, com desmame aos 21 dias. Os lactentes foram numerados e distribuídos em categorias de peso. Os tetos foram delimitados em lados esquerdo e direito, formando classes. $O$ registro dos tetos onde os lactentes mamaram e as disputas foram realizados do segundo dia de nascimento até o desmame, três vezes por semana, em duas avaliações diárias. A imposição da hierarquia foi atribuída pelo registro de comportamentos agonísticos entre os leitões, identificando o emissor, receptor, o tipo do comportamento realizado pelo agressor e a contra reação do agredido. Maiores médias de procura pelas tetas foram encontradas nas classificações intermediária, superior e inferior, sem diferença estatística entre os ambientes e os períodos do dia. No estabelecimento da hierarquia não foi encontrado um animal estritamente dominante, intermediário ou subordinado. Leitões classificados como mais pesados ao nascimento foram mais pesados ao desmame nos dois ambientes avaliados. Conclui-se que a sequência dos leitões na glândula mamária influencia no ganho de peso dos suínos ao final da fase de maternidade.

\subsection{Introdução}

Fêmeas suínas apresentam comportamento característico em relação a seus leitões, marcado, especialmente, pela amamentação que ocorre em intervalos regulares de 45 a 50 minutos, com vocalizações iniciais e sucessivas emitidas pelas matrizes e massagens da glândula mamária pelos leitões após ejeção do leite (ALGERS, 1993). Nos primeiros minutos após o nascimento, leitões se direcionam aos tetos para ingestão do colostro, gerando disputas iniciais agressivas por hierarquia. Em até uma semana, os lactentes elegem um ou dois tetos na glândula mamária, onde dificilmente serão observadas novas disputas (HARTSOCK; GRAVES, 1976; ROSILLON-WARNIER; PAQUAY, 1984).

A espécie suína tem seu conforto térmico prejudicado pelo confinamento intensivo, determinado pela restrição da movimentação e interações sociais decorrentes da diminuição

\footnotetext{
1 Submetido ao Journal of Veterinary Behavior-Clinical Applications and Research
} 
do espaço disponível (PUTTEN, 1989). Em estresse por calor, suínos empregam mecanismos fisiológicos como ofego para a redução da temperatura corporal (SARUBBI, 2009), apresentando alterações na postura e conduta materna, aliado ao comportamento ingestivo, responsáveis pela redução do desempenho de fêmeas suínas e suas leitegadas (QUINIOU; NOBLET, 1999; RENAUDEAU; NOBLET, 2001; RENAUDEAU et al., 2003).

Segundo Martins (2006) em altas temperaturas, a porca na maternidade altera seu comportamento de amamentar, que permanece diminuído, em consequência ao aumento das posições de decúbito ventral e sentada das matrizes, reduzindo o tempo de mamada e a produção de leite pela fêmea, devido a menor estimulação pelos leitões. De acordo com Ferreira (2005) matrizes expostas a $32^{\circ} \mathrm{C}$ apresentam redução de $25 \%$ da sua produção de leite, com resultados de menor peso das suas leitegadas. Para Cabrera (2001), o consumo alimentar das fêmeas, pode ser reduzido em $40 \%$, gerando redução da espessura do toucinho, aumento do intervalo da desmame e do cio, com prejuízo de $30 \%$ da produção de leite, reduzindo o tamanho da leitegada e o período de lactação.

A fase de maternidade apresenta necessidades térmicas específicas para leitões e porcas, uma vez que lactentes precisam maiores temperaturas quando comparados as porcas, tornando-se um desafio para a produção (TOLON; NAAS, 2005). Procurando melhorar a ambiência das instalações, a utilização de enriquecimentos ambientais físicos, como ventilação, nebulização e lâminas de água, reduzem o estresse, aumentando das taxas reprodutivas, restringindo distúrbios comportamentais e a mortalidade dos suínos (CARLSTEAD; SHEPHERDSON, 2000).

Estudos envolvendo a formação da ordem pelos tetos na glândula mamária foram realizados buscando avaliar sua estabilidade e determinar sua relação com ganhos de peso e hierarquia de dominância. Harstock e Graves (1976) e Scheel et al. (1977), que afirmaram que desde o nascimento, a disputa foi observada para obter as tetas da frente. (DONALD, 1937; GILL; THOMSON, 1956; HARSTOCK et al., 1977) mostraram uma preferência geral de leitões pela frente tetinas. Harstock et al. (1977) e Wesley (1967) indicaram o tempo para a definição da teta na glândula mamaria. No entanto, é necessário que se avalie se estas particularidades são alteradas em ambientes com climatização a partir de ventiladores e aspersores de água, com temperaturas próximas ao conforto térmico dos suínos e determinar a relação destas alterações com o ganho de peso dos animais.

Diante disso, este estudo foi elaborado com o objetivo de avaliar se há alterações hierárquicas de mamada de leitões alojados em ambientes climatizados em condições tropicais e a interferência destas mudanças no ganho de peso dos animais. 


\subsection{Material e Métodos}

O estudo foi conduzido nas instalações de maternidade do Setor de Suinocultura da prefeitura do campus Fernando Costa, na Universidade de São Paulo, Campus Fernando Costa, em Pirassununga, São Paulo. O local encontra-se em altitude de 340 metros, latitude sul de $21^{\circ} 80^{\prime} 00^{\prime \prime}$ e longitude oeste de $47^{\circ} 25^{\prime} 42 "$, clima Cwa com temperaturas anuais mínimas médias de 13 e máximas de $31^{\circ} \mathrm{C}$, segundo Koppen (2011). O presente trabalho foi aprovado pela Comissão de Ética no Uso de Animais CEUA № 3758260116 da FZEA/USP.

O sistema utilizado foi o de semiconfinamento em baias individuais para fêmea e leitegada com 1,80 m de largura, 4,20 m de comprimento, sem gaiolas, piso cimentado com cama de bagaço de cana, grade antiesmagamento de 3,20 m de comprimento, bebedouros tipo chupeta para fêmeas e leitões e comedouro tipo calha para leitões e de concreto para as fêmeas. Possuem escamoteadores com lâmpada para aquecimento dos leitões, separado da baia, por uma parede de 1,65 $\mathrm{m}$ de altura que permite acesso apenas dos lactentes a partir de uma abertura de 0,5 m de altura e 0,3 de largura. Nas baias havia duas correntes penduradas utilizadas como enriquecimento ambiental para ambas as idades (fêmeas e lactentes). A instalação possuía pé direito de 2,70 m, telhado constituído por telhas francesas e madeira e piso de concreto.

A maternidade foi dividida em climatizada e controle. Nas baias experimentais da área climatizada foram acrescidos ventiladores, da marca Ventisol de $60 \mathrm{~cm}$, três hélices, de potência 1/5CV - 147W; e 1200 rpm máxima. Foi utilizado um ventilador para cada duas fêmeas e suas respectivas leitegadas na altura de $1,80 \mathrm{~m}$ do piso, fixados no pilar e um aspersor/ irrigador de pulso com haste da marca TRAPP - DY-1013 para irrigação de água no telhado, fixados na mureta de modo que a agua alcançasse todo o telhado, sendo utilizados um aspersor para cada três fêmeas (baias). Os equipamentos foram ligados as 6 horas e desligados as 17, permanecendo continuamente ligados ao longo do dia.

A área controle era constituída por baias com cama de bagaço de cana, enriquecimentos ambientais e a mesma estrutura física da área climatizada, no entanto sem a presença de ventiladores e aspersores de água no telhado. Ambos os ambientes possuíam escamoteadores que permaneceram com suas lâmpadas acesas para os leitões durante todo o dia período experimental. As instalações foram separadas por lona plástica como forma de separar os ambientes, com a distância de 1,5 metros entre os tratamentos, impedindo circulação do ar oriundo dos ventiladores e umidade para o tratamento controle.

A temperatura interna no ambiente controle às 7 horas foi de $23,7^{\circ} \mathrm{C} \pm 0,64 \mathrm{com}$ umidade de $74 \% \pm 1,64$ e às 13 horas de $26,2^{\circ} \mathrm{C} \pm 1,23$ com umidade de $70,4 \% \pm 1,68$. No ambiente climatizado, às 7 horas a temperatura ambiental encontrada foi de $22,1^{\circ} \mathrm{C} \pm 0,66 \mathrm{com}$ umidade de $81,9 \% \pm 1,66$ e às 13 horas de $24,5^{\circ} \mathrm{C} \pm 0,85$ e umidade de $85,7 \% \pm 1,34$. 
Foram utilizadas 26 fêmeas, F1, Landrace $x$ Large White, de segunda ordem de parto e suas respectivas leitegadas, totalizando 281 leitões, sendo 154 fêmeas e 127 machos, com desmame aos vinte e um dias. O manejo nutricional era realizado de manhã e à tarde para fêmeas e leitões, com $7 \mathrm{~kg}$ ao dia para fêmeas e com aumento progressivo para os leitões, iniciando com 200 gramas na primeira semana e $500 \mathrm{~g}$ na semana do desmame.

No segundo dia após o nascimento, convencionalmente, os leitões passam por práticas rotineiras, como castração de machos, desgaste de dentes, caudoctemia, mossagem australiana e aplicação de ferro. Neste momento, os lactentes foram numerados, com algarismos arábicos, a partir de caneta não toxica, em ordem de sexo e peso, iniciando-se sempre pelos machos mais pesados, seguindo pelos machos mais leves, fêmeas mais pesadas e por fim as mais leves. Distribuíram-se os animais nas seguintes classes de acordo com o peso médio dos leitões ao nascimento em leves $(\leq 1,36 \mathrm{~kg})$; médios $(1,37$ a $2,13 \mathrm{~kg})$ e pesados $(>2,14 \mathrm{~kg})$. Os leitões foram pesados ao nascimento e três vezes por semana até o desmame e as fêmeas na entrada da fase de maternidade (7 dias antes do parto) e aos 21 dias pós parto. As leitegadas foram organizadas com 14 leitões.

Para a análise da hierarquia dos leitões na glândula mamária, primeiramente, o número total de tetos de cada porca foi obtido. O número mínimo de pares encontrados foram sete e o máximo de nove. Sequencialmente, foi estabelecida uma classificação para a localização dos tetos na glândula, em sentido craniocaudal, sempre iniciada pelo lado esquerdo seguida pelo lado direito. Os tetos foram numerados de 1 a 9 do lado esquerdo e de 10 a 18 do lado direito. Caso não houvesse tetos para o seguimento da numeração, os dígitos permaneceram na sequência, seguindo a classificação descrita para o lado da glândula (Figura 1).

Figura 1 - Classificação das tetas em superiores, medianas e inferiores em relação aos lados direito e esquerdo da glândula mamária

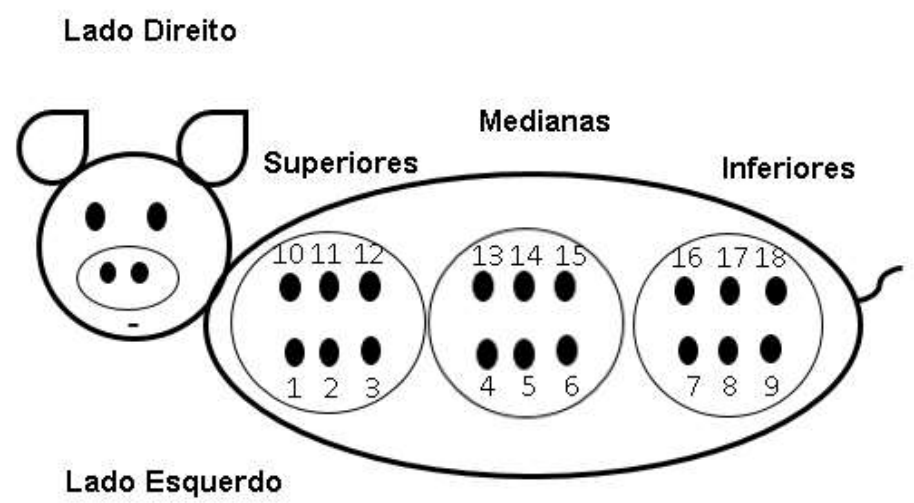

Fonte: Própria autoria 
O registro dos tetos onde os lactentes mamaram e a disputa por hierarquia foi realizada do segundo dia de nascimento até o desmame, três vezes por semana, com uma observação no período da manhã e outra à tarde, por observação focal direta, em posição estratégica, buscando menor interferência na mamada, realizada por dois observadores previamente treinados para esta função.

O apontamento da localização da teta onde o leitão mamava e a apresentação dos comportamentos foram avaliados de acordo com o lado que a fêmea permanecia em decúbito lateral para a amamentação. Portanto, caso estivesse deitada do lado esquerdo, a observação e marcação da teta iniciava-se em 1, caso estivesse do lado esquerdo, iniciava-se em 10, sempre seguindo a classificação.

A classificação em dominantes, intermediários e subordinados foi realizada por porca, agregando diferentes nomenclaturas para machos e fêmeas em relação a categoria de peso. Leitões machos foram definidos por números arábicos, começando pelos mais pesados até os mais leves, e as fêmeas por letras maiúsculas, na mesma ordem de peso.

A imposição da hierarquia foi atribuída pelo registro das ocorrências dos comportamentos agonísticos entre os leitões, por observação direta com rota de amostragem do comportamento (MARTIN; BATESON, 1993), em etograma específico para o registro. Para cada interação agonística foi identificado o emissor, receptor, o tipo do comportamento realizado pelo agressor e a contra reação do agredido.

O registro do comportamento realizado durante a imposição e definição da hierarquia de mamada foi obtido concomitantemente a observação da localização do animal a teta classificada, utilizando-se rotas de colheita pelo método focal direto e registro contínuo ou instantâneo, de acordo com o comportamento observado (MARTIN; BATESON, 1993).

A avaliação da hierarquia dos leitões na glândula mamária foi feita baseada nas ocorrências das interações agonísticas observadas entre os leitões durante a primeira etapa do estudo. A matriz binária de dominância foi construída baseada nas ocorrências das interações agonísticas identificando os indivíduos das linhas que dominam indivíduos das colunas (DE VRIES, 1995). O coeficiente de consistência Kendall de (K), com base no número de tríades circulares (d), foi utilizado para testar a linearidade das relações de dominância, que deveriam ser significativamente mais fortes do que o esperado, em tentativa de organizar os indivíduos em uma hierarquia linear (APPLEBY, 1983; DE VRIES, 1998).

Para a divisão em três níveis de hierarquia foi utilizada metodologia adaptada de (ECCLES; SHACKLETON, 1986 adaptado de SOARES, 2015) três níveis de hierarquia (dominante, intermediário, subordinado), utilizando catorze animais por leitegada.

Os dados foram analisados por variância com efeitos fixos de tratamento (climatizado ou controle), período do dia (manhã ou tarde), sexo (macho e fêmea), categoria de peso e suas interações. Para os efeitos significativos as médias foram comparadas por teste t a $5 \%$. 


\section{$2.3 \quad$ Resultados}

O período foi incluído como efeito fixo, mas como não houve efeito sobre nenhum parâmetro ele foi retirado da análise. Entre os parâmetros avaliados, nenhum interagiu. No ambiente controle o número de brigas durante as mamadas foi maior em relação ao climatizado, sendo 127 e 85 disputas, respectivamente, ao longo das três semanas de avaliações $(\mathrm{P}<0,05)$. Entretanto, mesmo com o número de brigas maior no ambiente controle, não diferiram entre ambiente, semana e períodos do dia $(P>0,05)$. A continuidade da disputa ao longo das semanas até o desmame, está relacionado a briga pela mesma classe de tetos pelos leitões (Tabela 1).

Nas tetas superiores não houve diferença estatística para disputas pelas tetas entre leitões de peso leve e médio uma vez ambas as categorias estiveram nessas tetas em frequências semelhantes. Os leitões pesados disputaram menos a classe de tetas superiores que leitões leves e médios $(P<0,05)$ (Tabela 1$)$.

A apresentação das maiores médias de procura por tetas pelos leitões na glândula mamária encontradas nas classificações medianas (peitorais), superior (anteriores) e inferior (inguinais) $(\mathrm{P}<0,01)$, não apresentando diferenças entre o ambiente controle e climatizado e para os períodos da manhã e da tarde $(P>0,05)$.

Tabela 1- Preferências pelos tetos na glândula mamária de porcas de acordo com a categoria de peso dos leitões

\begin{tabular}{|c|c|c|c|c|c|c|c|c|c|}
\hline \multirow{3}{*}{$\begin{array}{c}\text { Classe de } \\
\text { Tetos }\end{array}$} & \multicolumn{9}{|c|}{ Categoria de Peso } \\
\hline & \multicolumn{3}{|c|}{ Leves } & \multicolumn{3}{|c|}{ Médios } & \multicolumn{3}{|c|}{ Pesados } \\
\hline & Evento & EL & $\%$ & Evento & $\mathrm{EL}$ & $\%$ & Evento & $\overline{E L}$ & $\%$ \\
\hline Superiores & $74,5 \mathrm{Ab}$ & 5,3 & 27,0 & $65,5 \mathrm{Ab}$ & 4,6 & 27,8 & $26 \mathrm{Bb}$ & 1,8 & 21,1 \\
\hline Medianas & $144 \mathrm{Aa}$ & 10,2 & 52,4 & $129,5 \mathrm{Aa}$ & 9,2 & 53,9 & $75 \mathrm{Ba}$ & 5,3 & 60,3 \\
\hline Inferiores & $56 \mathrm{Ab}$ & 3,9 & 20,4 & $44 A c$ & 2,1 & 18,2 & $23 \mathrm{Bb}$ & 1,6 & 18,5 \\
\hline
\end{tabular}

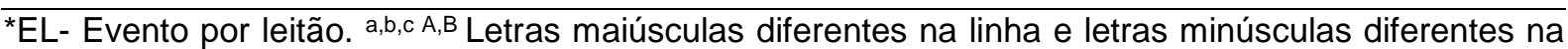
coluna, para a mesma característica, diferem entre si por T de Student a 5\%. Fonte: Própria autoria

Em relação ao estabelecimento da hierarquia não foi encontrado um animal estritamente dominante, intermediário ou subordinado. Cinco animais foram classificados como dominantes, seis intermediários e três subordinados, de acordo com a categoria de peso e o sexo dos animais, (Tabela 2). 
Tabela 2- Demonstrativo de leitões classificados como dominantes, intermediários e subordinados em relação ao sexo e a média de peso ao nascimento na competição pelas tetas na glândula mamária

\begin{tabular}{ccccc}
\hline Classificação & Leitão & Sexo & Média de Peso(Kg) & DP \\
\hline \multirow{5}{*}{ Dominantes } & 1 & Macho & 2,07 & 0,29 \\
& 3 & Macho & 1,71 & 0,29 \\
& D & Fêmea & 1,68 & 0,29 \\
& 4 & Macho & 1,61 & 0,32 \\
& B & Fêmea & 1,9 & 0,30 \\
\hline \multirow{5}{*}{ Intermediários } & C & Fêmea & 1,71 & 0,34 \\
& G & Fêmea & 1,14 & 0,24 \\
& 5 & Macho & 1,49 & 0,40 \\
& E & Fêmea & 1,55 & 0,32 \\
& F & Fêmea & 1,33 & 0,22 \\
Subordinados & 2 & Macho & 1,9 & 0,35 \\
\hline & A & Fêmea & 2,08 & 0,34 \\
& 6 & Macho & 1,38 & 0,28 \\
& 7 & Macho & 1,27 & 0,10 \\
\hline
\end{tabular}

DP* Desvio Padrão; As letras representam as fêmeas e os números machos. Fonte: Própria autoria

O sexo não influenciou na classificação de hierarquia dos leitões, uma vez que animais de ambos os sexos foram classificados como dominantes, intermediários e subordinados. Neste estudo, o peso dos leitões pode ter sido o fator de determinação hierárquico, uma vez que houve variação da faixa de peso de machos e fêmeas. Durante todo o período de avaliação houve competição pelas tetas, denotando que animais menores se dirigiram a tetos das classificações superiores e intermediárias, permanecendo nestas enquanto animais pesados competiam pela dominância. No entanto, neste estudo foi observado que animais menores foram classificados como intermediários e subordinados, permanecendo como dominantes os animais considerados pesados, indicando que ao longo dos vinte e um dias, eles retornaram as tetas inicialmente mamadas, tirando os menores das tetas.

Notou-se que animais pesados foram encontrados nas categorias intermediários e subordinados e este fato pode estar relacionado ao número de animais dominantes dentro de cada leitegada. No ambiente climatizado, leitões leves e médios apresentaram crescimento semelhante, no entanto, animais médios apresentaram maior peso médio em relação aos animais leves, sendo que animais pesados continuaram apresentando maior peso ao desmame em relação as duas categorias anteriores ( $P>0,01)$ Por mamarem em tetos superiores e medianos os leitões leves e intermediários poderiam ter sido mais pesados a desmama. No ambiente controle, leitões das categorias leves, médios e pesados tiveram ganho de pesos diferentes ao longo dos vinte e um dias, onde os mais pesados foram encontrados na categoria pesados $(P>0,01)$ (Tabela 3$)$. 
Leitões que nascem maiores tendem a serem mais pesados ao desmame uma vez que na disputa pelas tetas possuem maior habilidade e possibilidade de mamar em tetos onde a produção de leite é maior, assim como sua ingestão, tornando-os mais pesados ao desmame.

Tabela 3-Peso ao desmame em $\mathrm{kg}$ de acordo com as categorias definidas ao nascer diante dos ambientes avaliados

\begin{tabular}{cccc}
\hline \multirow{2}{*}{ Ambiente } & \multicolumn{3}{c}{ Categoria de pesos em kg } \\
\cline { 2 - 4 } & Leves & Médios & Pesados \\
\hline Controle & $4,21 \pm 0,087 \mathrm{Aa}$ & $5,32 \pm 0,055 \mathrm{Ba}$ & $6,56 \pm 0,090 \mathrm{Cb}$ \\
Climatizado & $3,87 \pm 0,089 \mathrm{Bb}$ & $5,68 \pm 0,058 \mathrm{Ba}$ & $7,22 \pm 0,103 \mathrm{Ca}$ \\
\hline a,b A,B,C Letras maiúsculas diferentes na linha e letras minúsculas diferentes na coluna diferem entre si \\
por Teste t a 5\%. Fonte: Própria autoria
\end{tabular}

$\mathrm{Na}$ comparação entre os ambientes controle e climatizado, para leitões leves e pesados foram encontradas diferenças estatísticas entre os tratamentos $(P<0,01)$, enquanto que para os animais médios o ambiente não interferiu nos resultados $(P>0,05)$.

Leitões classificados como leves apresentaram menor peso ao desmame no ambiente climatizado quando comparados ao ambiente controle, estando isso relacionado a maior superfície corporal dos leitões expostos a temperatura de conforto para fêmea, o que é menor para leitões médios e pesados, que possuem menor superfície corporal exposta ao ambiente, mantendo melhor sua temperatura corporal.

Leitões dominantes foram definidos como os animais com maior média de peso, no entanto, leitões intermediários e subordinados tiveram praticamente o mesmo peso na desmama $(P<0,01)$.

Em relação as fêmeas, o peso ao desmame e a perda de peso da maternidade não apresentaram efeito dos ambientes, com médias de $260,9 \mathrm{~kg} \pm 25,2$ no ambiente climatizado e $239,3 \mathrm{~kg} \pm 25,6$ no controle $(P>0,05)$.

\section{Discussão}

Durante a amamentação, os leitões tem preferência por glândulas mamárias peitorais, especialmente porque nelas o leite contém maiores teores de proteína, principalmente as imunoglobulinas do colostro, que contribuem para imunidade passiva de maior qualidade, além de outras proteínas que permitem melhorar o desenvolvimento intestinal dos lactentes (WU et al., 2010), assim como açucares e gordura, apresentam tetos mais flácidos e compridos, que auxiliam na sucção, seguido de tetos abdominais e por fim as tetas da região inguinal da glândula mamária (CASTRO; MURGAS, 2015).

Além do maior potencial de produção de leite, as tetas anteriores proporcionam posição mais confortável para a mamada, em relação às glândulas posteriores, tornando-as 
mais disputadas (GILL; THOMSON, 1956; HEMSWORTH et al., 1976a). Entretanto, neste estudo, os resultados divergem deste contexto, com apresentação das maiores médias de procura por tetas pelos leitões na glândula mamária encontradas nas classificações intermediária (peitorais), superior (anteriores) e inferior (inguinais), respectivamente.

Devido a ocorrência de maiores disputas pelas tetas das classes intermediárias, podese indicar que os animais brigaram por essas tetas por preferirem o tipo de teto ou que não podiam mamar em outras porque já estariam ocupadas por animais maiores, confirmado pelo fato de terem sido encontrados animais definidos como pesados em todas as classes de tetas. Em seu estudo, Furtado et al. (2009), encontraram que os três primeiros pares de tetos (superiores) foram os mais procurados, com 18,6\%, 17,7\% e 18,2\% para o par um, dois e três, respectivamente e $70,7 \%$ dos leitões mamaram nos quatro primeiros pares, corroborando com os resultados de Kim et al. (2000) que descreveram que $60 \%$ dos leitões mamaram nestes tetos. Segundo Algers (1993), na tentativa de mamar em outro teto, o leitão pode perder seu lugar na glândula mamária, iniciando novas brigas devido ao comportamento territorialista dos leitões diante dos tetos (HARTSOCK; GRAVES, 1976).

Ishiwata et al. (2002) afirmaram que o número de agressões em leitões desmamados aos 28 dias do mesmo sexo é maior em relação ao sexo oposto, e assim observa-se que animais do mesmo sexo quando alojados em grupos, apresentam maior frequência de brigas. Colson et al. (2006a) observaram a mesma correlação, contudo eles descreveram que há um aumento de eventos agonísticos, possivelmente determinados pela instabilidade social provocada pela presença do sexo oposto no desmame. Para a terminação, Stookey et al. (1994) avaliando o comportamento agressivo de suínos reagrupados, não verificaram diferenças significativas no primeiro dia entre os sexos, observando, no entanto que em fêmeas, no segundo dia após o reagrupamento, há maior apresentação de agressividade.

Segundo Mores et al. (1998), de maneira natural, leitões mais pesados, por serem mais espertos e fortes, se fixam nas glândulas mamárias peitorais, os leitões intermediários permanecem nas tetas abdominais, e os leitões menores e mais fracos situam-se em tetas na região inguinal da glândula mamária. A competição pelos tetos é mais notada quando as leitegadas são grandes, quando a produção de leite é baixa, quando existe grande variância de peso ao nascer dos leitões ou quando o tamanho da leitegada supera o número de tetos (BURGUER, 1993; DE PASSILE; RUSHEN, 1988; ELLENDORF et al., 1982; FRASER, 1984; MCBRIDE, 1963; WEARY; FRASER, 1999).

Leitões maiores ao nascimento são mais fortes e por isso realizam um estímulo mais eficiente da glândula mamária (ALGERS; JENSEN, 1991; HARTMAN; LUDWICK; WILSON, 1962; KING et al., 1997; SCHEEL; GRAVES; SHERRITT, 1977), resultando em maior fluxo sanguíneo para a glândula mamária e na auxiliando na autorregulação da produção de leite (FRASER, 1984b; FURTADO et al., 2009). Após a mamada, os lactentes retomam a 
massagem mesmo sem haver liberação de leite (ELLENDORFF; FORSLING; POULAIN, 1982), sendo esta massagem um marcador olfatório que facilita a determinação de tetos McBride (1963) e é o momento em que o leitão estimula a produção de leite dos tetos para a próxima mamada (ALGERS; JENSEN, 1985).

Segundo Bortolozzo et al. (2011) a temperatura da zona de conforto térmico da fêmea suína lactante está entre 16 e $24^{\circ} \mathrm{C}$ e a do leitão neonato entre 32 e $34^{\circ} \mathrm{C}$. Neste estudo foi utilizado o escamoteador, com área exclusiva para os leitões. No entanto, provavelmente devido a presença de cama de bagaço de cana na baia cimentada onde a fêmea permanecia e pela presença da mãe, foi observado que os leitões acomodavam-se próximos a ela, o que pode ter acarretado mais frio para os leitões leves no ambiente climatizado e aumento da mortalidade devido a esmagamentos pelas fêmeas. A hipotermia está entre as principais causas de mortalidade de leitões recém-nascidos (ENGLISH, 1998).

Em estresse térmico causado pelo frio, mesmo mamando, leitões podem ter hipoglicemia e o uso de escamoteadores é essencial para mantença do calor para esta fase da criação. Pereira e Passos (1998), avaliando leitões recém-nascidos com a variação da temperatura do corpo monitorada, indicaram que o controle da temperatura ambiental com a utilização de escamoteadores e aquecimento é indispensável para auxiliar os leitões na manutenção da homeotermia. Os leitões mais fracos são os mais suscetíveis, representando em torno de $65 \%$ do total de perdas da fase de maternidade (FERREIRA et al., 2007).

A ordem em que os leitões mamam na glândula mamária interfere no desenvolvimento dos lactentes, devido a variação na produção de leite de cada glândula mamária, sendo o principal condição que contribui para a variação de peso ao desmame dos leitões (FRASER et al., 1979; FRASER; JONES, 1975; HARTSOCK; GRAVES; BAUMGARDT, 1977; HEMSWORTH; WINFIELD; MULLANEY, 1976; ROSILLON-WARNIER; PAQUAY, 1984). Em seu estudo, Furtado et al. (2009), encontrou que leitões ao nascer com peso médio ao $(1,59$ $\pm 0,17 \mathrm{~kg})$ e elevado $(1,93 \pm 0,21 \mathrm{~kg})$ que mamaram nos pares classificados como cinco, seis e sete exibiram peso inferior (5420 $\pm 1130 \mathrm{~g}, 5900 \pm 1110 \mathrm{~g}$, respectivamente) ao desmame, com 21 dias de idade, em comparação a leitões que mamaram nos pares um (6660 $\pm 1100 \mathrm{~g}$, $7400 \pm 1130 \mathrm{~g}$, respectivamente), dois, três e quatro $(6140 \pm 1120,6600 \pm 1200 \mathrm{~g}$, respectivamente). No entanto, Stull et al. (1999) não observaram diferença no peso ao desmame com 28 dias entre leitões que mamaram nas classificações de primeiro $(6760 \mathrm{~g})$, quarto $(6660 \mathrm{~g})$ ou sexto par de tetas $(6770 \mathrm{~g})$.

Os ambientes melhoraram o conforto das fêmeas pela menor temperatura e a presença de água no ambiente climatizado tornou-se um atrativo para as matrizes que procuraram áreas com gotejamento nos horários mais quentes do dia. No ambiente controle, importante fator de perda de calor foi a área úmida oriunda da limpeza dos dejetos, dos dejetos e da água dos bebedouros. Estes fatores permitiram a troca de calor pelas fêmeas por 
evaporação e principalmente por condução, ocasionando perda de peso semelhantes nos dois ambientes.

\subsection{Conclusão}

Esperava-se que com a climatização houvesse uma redução das disputas pelos tetos no ambiente climatizado, devido a temperatura fora da zona de conforto dos leitões, assim como os machos mais pesados seriam os animais dominantes dentro das leitegadas e que ao longo das semanas após o nascimento as brigas diminuiriam cessando com a definição hierárquica nos tetos, contudo, a definição hierárquica em indivíduos dominantes, intermediários e subordinados não teve influência dos ambientes, das semanas até o desmame e do sexo. Apenas o peso influenciou na escolha das tetas na glândula mamária e o que refletiu na hierarquia da leitegada. 


\section{Referências}

ALGERS, B. Nursing in pigs: communicating needs and distributing resources. Journal of Animal Science, Cary, v. 71, p. 2826-2831, 1993.

APPLEBY, M. C. The probability of linearity in hierarchies. Animal Behaviour, London, v. 31, p. 600-608, 1983.

BÜRGER, A. Untersuchungen über die folgen der zahnresektion beim ferkel. 1993. 101 f. Tese (Doutorado) - Hannover: Tierärztlichen Hoschscule, 1993.

CABRERA, R. Abate com peso elevado: a experiência americana. Disponível em: $<$ https://www.suinoculturaindustrial.com.br/imprensa/assuntos-sugeridos-pelos-clientesfazem-sucesso-no-4o-seminario-agroceres/20010810-122801-0920>. Acesso em: 15 ago. 2018.

CASTRO, H. F.; MURGAS, L. D. S. Manejo na maternidade de suínos. 2015. Disponível em: <file:///C:/Users/Cliente/Downloads/bol_90.pdf>. Acesso em: 01 ago. 2018.

CARLSTEAD, K.; SHEPHERDSON, D. Alleviating stress in zoo animals with environmental enrichment. In: MOBERG, G. P.; MENCH, J. A. (Ed.). The Biology of animal stress: basic principles and implications for animal welfare. Wallingford: CABI, 2000. cap. 16, p. 337-354.

CALVIELLO, R. F. Estudo da influência do relacionamento entre a égua e o potro no comportamento social e no temperamento de potros da raça Mangalarga Marchador. 2016. 122 f. Tese (Doutorado) - Faculdade de Zootecnia e Engenharia de Alimentos, Universidade de São Paulo, Pirassununga, 2016.

COLSON, V. et al. Consequences of weaning piglets at 21 and 28 days on growth, behaviour and hormonal responses. Applied Animal Behaviour Science, Amsterdam, v. 98, p. 70-88, 2006.

DE PASSILE, A. M.; RUSCHEN, U. J. Ontogeny of teat fidelity in pigs and its relation to competition at suckling. Journal of Animal Science, Cary, v. 68 p. 325-338, 1988.

DE VRIES, $H$. An improved test of linearity in dominance hierarchies containing unknown or tied relationships. Animal Behaviour, London, v. 50, p.1375-1389, 1995.

DE VRIES, H. Finding a dominance order most consistent with a linear hierarchy: a new procedure and review. Animal Behaviour, London, v. 55, p. 827 843, 1998.

ECCLES, T. R.; SHACKLETON, D. M. Correlates and consequences of social status in female bighorn sheep. Animal Behaviour, London, v. 34, p. 1392-1401, 1986.

ELLENDORF, F.; FORSLING, U.; POULAIN, D. A. The milk ejection reflex in the pig. The Journal of Physiology, London, v. 333, p. 577-594, 1982.

FERREIRA, R. A. Maior produção com melhor ambiente para aves, suínos e bovinos. Viçosa: Aprenda Fácil, 2005.

FRASER, D. The role of behaviour in swine production: A review of research. Applied Animal Ethology, Amsterdam, v. 11, p. 317-339. 1984.

GILL, J. C.; THOMSON, W. Observations on the behavior of suckling pigs. British Journal of Animal Behaviour, London, v. 4, p. 46-51, 1956. 
HARTSOCK, T. G.; GRAVES, H. B. Neonatal behavior and nutrition-related mortality in domestic swine. Journal of Animal Science, Champaign, v. 42, p. 235-241, 1976.

HEMSWORTH, P. H.; WINFIELD, C. G.; MULLANEY, P. D. A study of development of the teat order in piglets. Applied Animal Ethology, Amsterdam, v. 2, p. 225-233, 1976.

ISHIWATA, T.; UETAKE, K.; TANAKA, T. Use of a box to prevent agonistic behavior after regrouping in isolated and non-isolated pigs. Animal Science Journal, Richmond, v. 73, p. 287-292, 2002.

KLOPFENSTEIN, C.; FARMER, C.; MARTINEAU, G. P. Diseases of the mammary glands and lactation problems. In: STRAW, B. E. D. et al. (Ed.). Diseases of swine. Ames-USA: lowa State University, 1999. cap. 8, p. 833-860.

MARTIN, P.; BATESON, P. Measuring behavior: an introductory guide. Cambridge: Cambridge University Press, 1993.

MARTINS, T. D. D.; COSTA, A. N.; SILVA, J. H. V. Comportamento alimentar de fêmeas suínas em lactação mantidas em ambiente quente. Archivos Zootecnia, Córdoba, v. 55, p. 109-112, 2006.

MORÉS, N. Influência da granulometria de ingredientes de dietas no desenvolvimento de lesões gástricas em suínos. In: SIMPÓSIO SOBRE GRANULOMETRIA DE INGREDIENTES E RAÇÓES PARA SUÍNOA E AVES, 3., 1998. Concórdia. Anais... Concórdia: EMBRAPA Suínos e Aves, 1998. p.13-25.

MCBRIDE, G. The "teat order" and communication in young pigs. Animal Behaviour, London, v. 11, p. 53-56, 1963.

PUTTEN, G. V. The pig: model for discussing animal behavior and welfare. Enciclopédia Biosfera, Goiânia, 1989.

QUINIOU, N.; NOBLET, J. Influence of high ambient temperature on performance of multiparous lactating sows. Journal of Animal Science, Champaign, v. 77, p. 2124-2134, 1999.

RENAUDEAU, D.; NOBLET, J. Effects of exposure to high ambient temperature and dietary protein level on performance of multiparous lactating sows. Journal of Animal Science, Champaign, v. 79, p. 1240-1249, 2001.

RENAUDEAU, D.; NOBLET, J.; DOURMAD, J.Y. Effect of ambient temperature on mammary gland metabolism in lactating sows. Journal of Animal Science, Champaign, v. 81, p. 217-231, 2003.

ROSILLON-WARNIER, A.; PAQUAY, R. Development and consequences of teat-order in piglets. Applied Animal Behaviour Science, Amsterdam, v. 13, p. 47-58, 1984.

SARUBBI, J. Bem-estar dos animais e uso racional de energia elétrica em sistemas de aquecimento para leitões desmamados. 2009. $190 \mathrm{f}$. Tese (Doutorado) - Faculdade de Engenharia Agrícola, Universidade Estadual de Campinas, 2009.

SOARES, D. R. Comportamento individual de bovinos Nelore e relações com desempenho em regime de confinamento e reprodução. 2015. 70 f. Tese (Doutorado) - Faculdade de Ciências Agrárias e Veterinárias, Universidade Estadual Paulista Júlio de Mesquita Filho, Jaboticabal, 2015. 
STOOKEY, J. M.; GONYOU, H. W. The effects of regrouping on behavioral and production parameters in finishing swine. Journal Animal Science, Cary, v. 72, art. 2804, 1994.

TOLON, Y. B.; NAAS, I. A. Avaliação de tipos de ventilação em maternidade de suínos. Engenharia Agrícola, Jaboticabal, v. 25, p. 565-574, 2005.

WU, W. Z. et al. Differential composition of proteomes in sow colostrum and milk from anterior and posterior mammary glands. Journal Animal Science, Cary, v. 88, p. 26572664, 2010. 


\section{COMPORTAMENTO E PREFERÊNCIA AMBIENTAL DE SUÍNOS MANTIDOS EM MATERNIDADE CLIMATIZADA LIVRE DE GAIOLAS}

\section{Resumo}

Suínos possuem amplo aspecto comportamental e quando alojados em ambientes causadores de estresse por calor buscam áreas úmidas e ventiladas. $O$ objetivo deste estudo foi avaliar o comportamento de leitões e porcas e a preferência ambiental de porcas em maternidade climatizada livre de gaiolas e suas intercorrências no bem-estar. Foram avaliadas 26 fêmeas e 281 leitões, linhagem Large White $x$ Landrace, mantidos em baias sem gaiolas climatizadas por ventiladores e aspersores de telhado e ambiente controle, localizadas na direção nortesul em clima tropical. As baias foram delimitadas em cinco áreas, cada qual com uma possibilidade de escolha. Além da preferência foram avaliados os comportamentos agonísticos, alimentação, beber, eliminar, estereotipias, exploratório, lúdico, mamar (leitões) e ócio por amostragem scan, durante duas horas, a cada dez minutos, de manhã e à tarde, durante vinte e um dias. A frequência respiratória foi colhida duas vezes por período. Foram obtidas a temperatura superficial corporal das fêmeas e amostras dos leitões com câmera termográfica. As medidas de comportamento e de preferência ambiental foram analisadas por análise de variância Mixed para os leitões e Glimmix para as fêmeas com efeitos de ambiente, período do dia com médias comparadas utilizando o teste $t$-Student (SAS). As imagens termográficas foram analisadas utilizando o software IRSoft Version 3.6 Testo Thermal Imagers. O comportamento das fêmeas e leitões mais observado nos dois horários e ambientes foi o ócio, com maior frequência respiratória a tarde, no ambiente controle. As fêmeas preferiram a área que possuía os bebedouros e ventiladores (lado esquerdo), procurando áreas úmidas sem cama (lado da frente) no período da tarde. Conclui-se com este estudo que o número de mamadas foi diminuída no entanto aumento de comportamento inatos dos suínos, com procura por áreas diferentes da baia ao longo do dia possibilitando melhor bem-estar dos suínos na maternidade.

\subsubsection{Introdução}

O suíno apresenta amplo aspecto comportamental, alta capacidade de aprendizado e curiosidade (KILGOUR; DALTON, 1984; SOBESTIANSKY et al., 1991) e como animais gregários formam grupos sociais duradouros, com predominância de hierarquia social intensa (FRASER; BROOM, 1990). Do complexo de comportamento exercidos pelos suínos, o comportamento exploratório é considerado como um dos mais importantes para a sobrevivência natural da espécie (PINHEIRO, 2009). Em ambientes seminaturais, suínos tendem a permanecer $52 \%$ do dia fuçando ou pastando e $23 \%$ investigando o ambiente (GRANDIN; JONHSON, 2009). 
Em confinamento, instalações com gaiolas restringem as atividades e comportamentos dos suínos acarretando a manifestação de sentimentos negativos, como a frustração e estereotipias que os direcionarão a comportamentos investigativos entre si ou na direção de equipamentos presentes nas baias (SARUBBI, 2011). O comportamento estereotipado mostra-se como um mecanismo compensatório diante da privação comportamental, a partir de atividades repetitivas, como morder objetos ou caminhar por tempo prolongado, sem função aparente (FRASER; BROOM, 1990), assim como comportamento agonístico, descrito como aquele em que os animais brigam (CAMPOS et al., 2010) e o apático, definido como a inatividade dos suínos, indicando a dificuldade de interação do animal com o meio ambiente (BROOM, 1991).

Modificações no ambiente podem melhorar a bem-estar dos animais, satisfazendo suas necessidades comportamentais e fisiológicas (BRACKE et al., 2006). A retirada das gaiolas, a inserção de camas, barras antiesmagamento para proteção dos leitões e a inclusão de ventiladores e aspersores de água são alternativas práticas e simples que podem reduzir a apresentação de comportamentos negativos e melhorar a temperatura ambiental dentro do confinamento, sendo uma alternativa utilizada como enriquecimento ambiental físico.

Diante das dificuldades encontradas no ambiente onde estão alojados, os suínos tendem a se adaptar, buscando realizar comportamentos inatos com maior facilidade. Mantendo as porcas e seus leitões em baias livres de gaiolas, os suínos apresentam preferência por determinadas áreas, em diferentes períodos do dia, de acordo com a melhor condição para sua categoria fisiológica e comportamental.

Para a implantação do enriquecimento ambiental é preciso avaliar as necessidades especificas dos animais (VAN DE WEERD et al., 2003), uma vez que a utilização de programas de enriquecimento ambiental podem ser ineficazes, ou produzirem apenas benefício a curto prazo melhorando pouco o bem-estar dos suínos (TAROU; BASHAW, 2007). A deficiência ambiental e o manejo errôneo acarretam prejuízos no bem- estar (SARUBBI, 2009), no entanto com o reparo dessas deficiências, ocorre melhoria dos índices produtivos e de bem-estar animal (SOMMAVILLA, 2008).

De acordo com o papel fundamental do comportamento nas adaptações das funções biológicas mostrando a parte do organismo que interage com o ambiente (SNOWDON, 1999), a avaliação de mudanças comportamentais é tida como uma das metodologias mais práticas e rápidas de análise de bem-estar animal (POLETTO, 2010), sendo possível mensurar a partir dela o estado dos indivíduos em relação ao seu ambiente de alojamento (BROOM, 1991). Os testes de preferência e motivacionais surgem como ferramenta estimada para a identificação de condições de bem-estar, tendo como princípio a instrução de que os animais optam por alternativas que atendam melhor seu bem-estar e bem-estar (DUCAN; FRASER, 1997). 
De acordo com a importância das alternativas para melhorar o ambiente de confinamento e as estratégias comportamentais utilizadas por suínos para se adaptar ao ambiente, este estudo tem como objetivo avaliar o comportamento de leitões e porcas mantidos em baias livres de gaiolas e a preferência ambiental de porcas em ambiente climatizado e controle.

\subsection{Material e Métodos}

\subsubsection{Instalações e animais}

O estudo foi conduzido nas instalações de maternidade do Setor de Suinocultura, na Universidade de São Paulo, Campus Fernando Costa, em Pirassununga, São Paulo. O local encontra-se em altitude de 340 metros, latitude sul de $21^{\circ} 80^{\prime} 00^{\prime \prime}$ e longitude oeste de 47²5'42", clima Cwa com temperaturas anuais mínimas médias de 13 e máximas de $31^{\circ} \mathrm{C}$, segundo Koppen (2011), com orientação norte-sul. O presente trabalho foi aprovado pela Comissão de Ética no Uso de Animais № 3758260116 da Faculdade de Zootecnia e Engenharia de Alimentos da Universidade de São Paulo.

O sistema utilizado foi o de semiconfinamento em baias individuais para fêmea e leitegada com 1,80 m de largura, 4,20 m de comprimento, sem gaiolas, piso cimentado parcialmente coberto com cama de bagaço de cana, grade antiesmagamento de 3,20 m de comprimento, bebedouros tipo chupeta para fêmeas e leitões e comedouro tipo calha para leitões e de concreto para as fêmeas. Possui escamoteador com lâmpada para aquecimento dos leitões, separado da baia, por uma parede de 1,65 $\mathrm{m}$ de altura que permite acesso apenas dos lactentes a partir de uma abertura de 0,5 m de altura e 0,3 de largura. Cada baia possui duas correntes penduradas utilizadas como enriquecimento ambiental para ambas as idades (fêmeas e lactentes). A instalação possui pé direito de 2,70 m, telhado constituído por telhas francesas e madeira com piso de concreto.

A maternidade foi dividida em climatizada e controle. Nas baias experimentais da área climatizada foram acrescidos ventiladores, da marca Ventisol de $60 \mathrm{~cm}$, três hélices, de potência 1/5CV - 147W; e 1200 rpm máxima. Foi utilizado um ventilador para cada duas fêmeas e suas respectivas leitegadas na altura de 1,80 m do piso, fixados no pilar e um aspersor/ irrigador de pulso com haste da marca TRAPP - DY-1013 para irrigação de água no telhado, fixados na mureta de modo que a agua alcançasse todo o telhado, sendo utilizados um aspersor para cada três fêmeas (baias).

A área controle era constituída por baias com cama de bagaço de cana, enriquecimentos ambientais e a mesma estrutura física da área climatizada, no entanto sem a presença de ventiladores e aspersores de água no telhado. Ambos os ambientes possuíam escamoteadores que permaneceram com suas lâmpadas acesas para os leitões durante todo 
o dia período experimental. As instalações foram separadas por lona plástica como forma de separar os ambientes, com a distância de 1,5 metros entre os tratamentos, impedindo circulação do ar oriundo dos ventiladores e umidade para o tratamento controle. Observa-se que houve controle das temperaturas, mostrando ambientes termicamente diferentes.

A temperatura interna no ambiente controle as 7 horas foi de $23,7^{\circ} \mathrm{C} \pm 0,64$ com umidade de $74 \% \pm 1,64$ e as 13 horas de $26,2 \pm 1,23$ com umidade de $70,4 \pm 1,68$. No ambiente climatizado, as 7 horas a temperatura ambiental encontrada foi de $22,1^{\circ} \mathrm{C} \pm 0,66 \mathrm{C}$ com umidade de $81,9 \% \pm 1,66$ e as 13 horas $24,5^{\circ} \mathrm{C} \pm 0,85$ e umidade de $85,7 \pm 1,34$.

Foram utilizadas 26 fêmeas, F1, Landrace $x$ Large White, de segunda ordem de parto e suas respectivas leitegadas, totalizando 281 leitões, sendo 154 fêmeas e 127 machos, com desmame aos vinte e um dias. No segundo dia após o nascimento, convencionalmente, os leitões passam por práticas rotineiras, como castração de machos, desgaste de dentes, caudoctemia, mossagem australiana e aplicação de ferro. Neste momento, os lactentes foram numerados, com algarismos arábicos, a partir de caneta não toxica, em ordem de sexo e peso, iniciando-se sempre pelos machos mais pesados, seguindo pelos machos mais leves, fêmeas mais pesadas e por fim as fêmeas mais leves. O manejo nutricional era realizado de manhã e à tarde para fêmeas e leitões, com $7 \mathrm{~kg}$ ao dia para fêmeas e com aumento progressivo para os leitões, iniciando com 200 gramas na primeira semana e $500 \mathrm{~g}$ na semana do desmame.

\subsubsection{Análise etológica de leitões e porcas}

Para obtenção de dados comportamentais, foi construído um etograma (DEL-CLARO 2004) para amostragem da frequência de realização do comportamento dos leitões e das porcas, individualmente, incluindo na análise de preferência ambiental das porcas. Entre os comportamentos avaliados estão: agonístico, alimentação, beber, defecação, estereotipias, exploratório, lúdico, mamar (leitões), micção e ócio (Tabela 4).

A observação dos leitões e matrizes suínas ocorreu de forma dirigida (FERREIRA et al., 2005) de modo a não afetar o comportamento natural, por amostragem escaneamento (MARTIN; BATESON, 1993). Dois observadores foram treinados para identificar os principais pontos comportamentais dos animais, em escala previamente definida. A colheita de dados foi realizada durante dez minutos, por duas horas, três vezes por semana, durante vinte e um dias para todas as fêmeas e suas leitegadas, totalizando cinco meses de avaliações.

A frequência respiratória foi obtida por observação visual direta e a contagem dos movimentos do flanco das porcas e parcela dos leitões (cinco animais por leitegada) por 1 minuto, uma vez no início e outra no final da avaliação de comportamento. 


\subsubsection{Análise de preferência ambiental das porcas}

Para colheita de dados relativos a preferência das fêmeas pelos locais dentro das baias, a posição comportamental (decúbito lateral, ventral, em pé e sentada) da fêmea não foi levada em consideração, considerada apenas a sua localização dentro da baia.

As baias foram delimitadas em cinco áreas: lado direito, com barra antiesmagamento, lado esquerdo com bebedouros para matrizes e leitões e ventiladores, lado de trás com cama de bagaço de cana e comedouros, meio da baia com cama e enriquecimento ambiental de corrente e lado da frente sem cama. No ambiente climatizado a área da frente era constituída por água oriunda dos aspersores posicionados sobre o telhado. Na área controle, a área da frente foi considerada área úmida (uma vez que não havia água do aspersor no telhado), mas permanecia úmida com água oriunda do bebedouro pelo acionamento das porcas, presença de dejetos e após a limpeza realizada pelos funcionários. Em ambos os ambientes, apenas a região da frente das baias não possuía área coberta pelo telhado, recebendo diretamente luz solar (Figura 2).

Figura 2 - Demonstrativo da divisão da baia em áreas especificas para estudo de preferência ambiental pelas porcas

\section{NORTE}

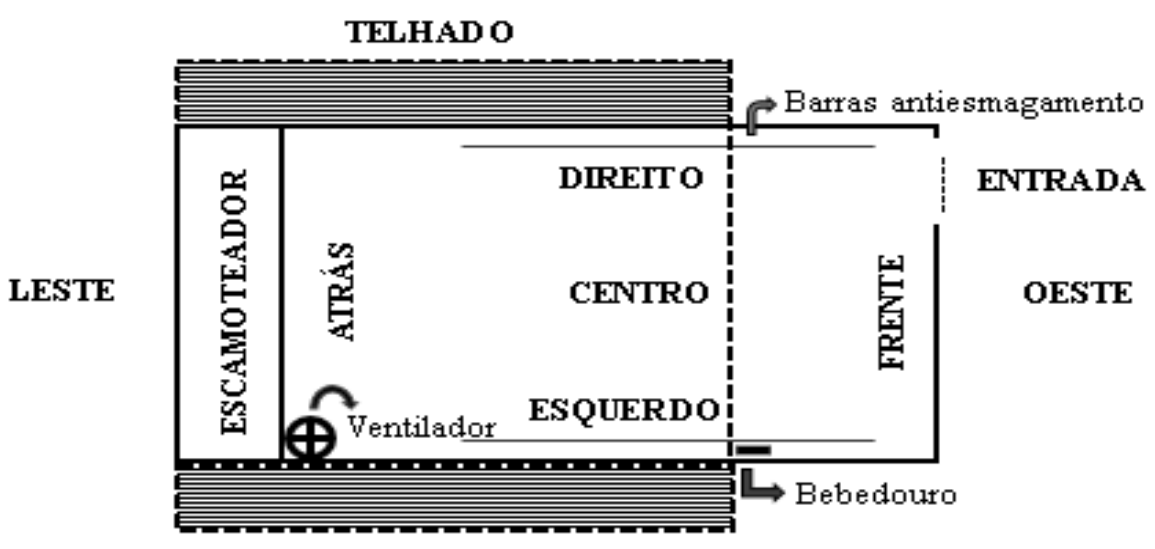

SUL

Fonte: Própria autoria

A observação das matrizes suínas em relação a preferência ambiental se deu na forma dirigida (FERREIRA et al., 2005) de modo a não afetar o comportamento natural das mesmas, por amostragem de escaneamento. As observações intervalares foram obtidas a cada dez minutos, durante uma hora, por vinte e um dias. Dois observadores foram treinados para identificar os principais pontos comportamentais dos animais, baseando-se em escala previamente definida. 
As medidas de comportamento e de preferência ambiental foram analisadas por análise de variância, utilizando o procedimento Mixed para os leitões com efeitos de tratamento, hora e local e Glimmix para as fêmeas com efeitos de tratamento, hora e local por meio do programa SAS (2017) e as médias foram comparadas utilizando o teste t a $5 \%$.

Tabela 4- Descrição do etograma de trabalho com a descrição dos comportamentos observados durante a realização da análise etológica

\begin{tabular}{cc}
\hline Comportamentos & Descrição \\
\hline Alimentação & Ingestão de ração do comedouro. \\
Agonístico & $\begin{array}{c}\text { Ato em que dois ou mais animais se agridem por meio } \\
\text { de perseguição, empurrões, mordidas, cabeçadas entre } \\
\text { outros. } \\
\text { Beber } \\
\text { Eliminar } \\
\text { Ato em que o animal realiza o acionamento do } \\
\text { bebedouro tipo chupeta consumindo água. } \\
\text { Ato de defecar e urinar. } \\
\text { Comportamento compensatório apresentado através de } \\
\text { atividades repetitivas ou viciosas, sem funções } \\
\text { adaptativas, como mastigação falsa, engolir o ar, } \\
\text { chupar ou enrolar a língua, morder as barras ou parte } \\
\text { das instalações. } \\
\text { Revolver a cama, cheirar os objetos, explorando o } \\
\text { chão, parede, barra ou outras partes da baia com o } \\
\text { focinho, boca ou língua. } \\
\text { Suíno correndo dentro da baia com ou sem finalização } \\
\text { diversificada que acaba em rodopio ou parada, } \\
\text { jogando-se no chão ou sobre outro leitão. } \\
\text { Suíno parado, sem se deslocar, sem atividade aparente } \\
\text { écio vocalizando ou não. }\end{array}$ \\
\hline
\end{tabular}

Fonte: Própria autoria

\subsubsection{Análise de termografia de infravermelho}

A obtenção dos dados a partir de fotos da câmera termográfica ocorreu em dois horários (7:00 horas e 13:00 horas), buscando horários com temperaturas mais amenas e mais quentes do dia, realizadas com intervalos de sete dias, totalizando seis análises por fêmea. A avaliação foi realizada com os animais secos e em diferentes posturas nas quais foram consideradas as posições: decúbito lateral direito, esquerdo, sentados ou em pé. 
Para análise da temperatura de superfície corporal foram escolhidos aleatoriamente, três leitões por leitegada e de todas as porcas. Em cada colheita foram registradas sete medidas pontuais em leitões e nove nas porcas, sendo: Temperatura Superficial Dorsal (TSD), Temperatura Superficial Ventral (TSV), Temperatura Superficial da Pata (TSP), Temperatura Superficial do Pernil (TSPN), Temperatura Superficial da cabeça (TSC), Temperatura Superficial do focinho (TSF) e Temperatura Superficial Ocular (TSO) para os leitões com acréscimo da Temperatura Superficial da glândula mamária (TSGM) e vaginal (TSV) para as porcas.

Para as mensurações foi utilizada uma câmera termográfica (Thermal imager TESTO $875 \AA$, Lenzkirch, Alemanha). O equipamento foi calibrado para uma emissividade de 0,98 indicado para tecidos biológicos, a distância de 1 metro de para o registro dos dados. As imagens termográficas das temperaturas ao longo da superfície corporal foram pontos em cada área escolhida aleatoriamente nas fotos.

Foram aferidas as temperaturas do telhado, da cama de bagaço de cana e do piso de concreto, utilizando a câmera termográfica usando a emissividade de 0,95 indicada para estruturas físicas. As imagens termográficas das temperaturas ao longo da superfície das instalações foram pontos em cada área escolhida aleatoriamente nas fotos.

Os parâmetros meteorológicos: temperatura do ar, umidade relativa e a temperatura do globo negro foram registradas nas baias experimentais por meio de data logger (Onset $\mathrm{HOBO} \otimes \mathrm{TEMP} / \mathrm{RH} / 2$ ext channels) inseridos um para cada área (climatizada e controle) obtidas a cada 15 minutos, instalados no centro das baias a uma altura de 1,8 metros do solo para que os animais não tivesse acesso ao objeto. O dispositivo permaneceu no local durante todo o período experimental. As medidas de temperaturas ambientais e corporais foram obtidas e avaliadas simultaneamente.

As imagens termográficas foram analisadas utilizando o software IRSoft Version 3.6 Testo Thermal Imagers para determinar temperatura máxima da área avaliada. Foram utilizadas fotos obtidas com a câmera, a partir de um histograma, pela paleta "Arco- Íris" para a obtenção de pontos nas áreas corporais e estruturais, com escala de temperatura de $21^{\circ} \mathrm{a}$ $40,5^{\circ} \mathrm{C}$. Para relacionar os dados de termografia, temperatura superficial e o cortisol utilizouse o coeficiente de correlação de Pearson. Um nível de probabilidade de $\mathrm{P}<0,05$ foi escolhido como limite para significância estatística em todos os testes. Considerando que, níveis de probabilidade de entre 5 e $7 \%$ foram considerados como uma tendência.

\subsection{Resultados}

\subsubsection{Comportamentos das fêmeas}


Não houve interação entre os períodos e os ambientes $(P>0,05)$. As fêmeas permaneceram mais em ócio no ambiente climatizado $(P<0,01)$ e de manhã $(P>0,05)$.

Os comportamentos agonísticos e estereotipados foram mais observados no ambiente controle, com mais brigas apresentadas de manhã e as estereotipias a tarde $(P>0,05)$.

O comportamento exploratório foi mais apresentado pelas fêmeas de manhã $(P<0,01)$, no ambiente climatizado $(P>0,05)$. Brincadeiras direcionadas aos leitões ou aos enriquecimentos foram mais observadas pela manhã e no ambiente controle $(P<0,05)$.

As fêmeas alimentaram-se e eliminaram mais vezes no ambiente climatizado e de manhã $(P>0,05)$, enquanto procuraram o bebedouro mais vezes no ambiente controle $(P<0,01)$ e de manhã $(P>0,05 ;$ Tabela 5$)$.

Tabela 5- Comportamentos apresentados por fêmeas suínas em relação aos períodos do dia e aos ambientes avaliados

\begin{tabular}{ccccccc}
\hline \multirow{2}{*}{ Comportamentos } & \multicolumn{3}{c}{ Períodos } & \multicolumn{3}{c}{ Local } \\
\cline { 2 - 7 } & Manhã & Tarde & $\operatorname{Pr}>|\mathbf{t}|$ & Controle & Climatizado & $\operatorname{Pr}>|\mathbf{t}|$ \\
\hline Agonístico & $8,64 \pm 1,75$ & $7,39 \pm 0,22$ & 0,98 & $8,66 \pm 1,76$ & $7,38 \pm 0,20$ & 0,98 \\
Estereotipado & $0,27 \pm 0,10$ & $0,33 \pm 0,10$ & 0,67 & $0,35 \pm 0,11$ & $0,25 \pm 0,93$ & 0,48 \\
Exploratório & $5,10 \pm 0,41$ & $3,10 \pm 0,33$ & 0,02 & $3,20 \pm 0,34$ & $5,00 \pm 0,39$ & 0,08 \\
Lúdico & $0,44 \pm 0,14$ & $0,31 \pm 0,12$ & 0,49 & $0,85 \pm 0,17$ & $0,16 \pm 0,07$ & 0,08 \\
Ócio & $22,0 \pm 0,79$ & $20,0 \pm 0,76$ & 0,20 & $16,10 \pm 0,69$ & $27,7 \pm 0,81$ & 0,01 \\
Alimentação & $6,19 \pm 0,46$ & $5,60 \pm 0,42$ & 0,35 & $5,46 \pm 0,43$ & $6,33 \pm 0,44$ & 0,15 \\
Beber & $3,16 \pm 0,38$ & $2,82 \pm 0,35$ & 0,51 & $6,92 \pm 0,48$ & $1,26 \pm 0,20$ & 0,01 \\
Eliminação & $1,00 \pm 0,19$ & $0,6 \pm 0,14$ & 0,10 & $0,79 \pm 0,16$ & $0,91 \pm 0,18$ & 0,62 \\
\hline
\end{tabular}

Fonte: Própria autoria

\subsubsection{Comportamento de leitões}

Não houve interação entre os períodos e os ambientes $(P>0,05)$. Os leitões, diferente das fêmeas, permaneceram em ócio em maior tempo no período da tarde $(P<0,01)$ e no ambiente climatizado $(P>0,05)$.

O comportamento agonístico foi mais observado de manhã $(P<0,01)$ e maior no climatizado $(P>0,05)$. As estereotipias foram observadas em maior frequência no período da manhã e no ambiente controle $(P<0,01)$.

O comportamento exploratório foi mais apresentado de manhã e no ambiente climatizado $(P<0,05)$. O comportamento lúdico foi mais observado de manhã $(P<0,01)$ e no ambiente climatizado $(P>0,05)$.

Os leitões procuraram mais o comedouro de manhã e no ambiente controle $(P<0,01)$. Os comportamentos de beber e eliminar foram maiores à tarde $(P>0,05)$ e no ambiente 
controle $(P<0,01)$. Ainda, mamaram mais no ambiente controle em relação ao ambiente climatizado $(P<0,01)$ e de manhã $(P>0,05 ;$ Tabela 6$)$.

Tabela 6-Comportamentos observados em leitões durante os períodos da manhã e da tarde e ambientes controle e climatizado

\begin{tabular}{ccccccc}
\hline \multirow{2}{*}{ Comportamentos } & \multicolumn{3}{c}{ Períodos } & \multicolumn{3}{c}{ Ambiente } \\
\cline { 2 - 7 } & Manhã & Tarde & $\operatorname{Pr}>|\mathbf{t}|$ & Controle & Climatizado & $\operatorname{Pr}>|\mathbf{t}|$ \\
\hline Agonístico & $1,50 \pm 0,06$ & $0,50 \pm 0,04$ & 0,01 & $0,84 \pm 0,05$ & $0,97 \pm 0,06$ & 0,14 \\
Estereotipado & $0,03 \pm 0,03$ & $0,01 \pm 0,02$ & 0,01 & $0,32 \pm 0,03$ & $0,10 \pm 0,02$ & 0,01 \\
Exploratório & $18,2 \pm 0,20$ & $11,7 \pm 0,01$ & 0,01 & $14,2 \pm 0,20$ & $15,2 \pm 0,21$ & 0,05 \\
Lúdico & $2,30 \pm 0,09$ & $1,10 \pm 0,06$ & 0,01 & $0,16 \pm 0,07$ & $0,17 \pm 0,08$ & 0,29 \\
Ócio & $58,4 \pm 0,02$ & $68,5 \pm 0,02$ & 0,01 & $63,0 \pm 0,27$ & $64,0 \pm 0,29$ & 0,10 \\
Mamar & $17,2 \pm 0,21$ & $16,9 \pm 0,22$ & 0,29 & $17,8 \pm 0,21$ & $16,3 \pm 0,22$ & 0,01 \\
Alimentação & $0,20 \pm 0,02$ & $0,04 \pm 0,01$ & 0,01 & $0,14 \pm 0,02$ & $0,08 \pm 0,02$ & 0,05 \\
Beber & $0,11 \pm 0,02$ & $0,73 \pm 0,01$ & 0,13 & $0,16 \pm 0,02$ & $0,05 \pm 0,01$ & 0,01 \\
Eliminação & $0,28 \pm 0,03$ & $0,29 \pm 0,03$ & 0,83 & $0,40 \pm 0,03$ & $0,20 \pm 0,02$ & 0,01 \\
\hline
\end{tabular}

Fonte: Própria autoria

O período do dia influenciou a frequência respiratória dos leitões, com maiores médias para o período da tarde $\left(71 \mathrm{mov} \cdot \mathrm{min}^{-1}\right)$ em relação a manhã (59 mov. $\left.\mathrm{min}^{-1}\right)(\mathrm{P}<0,01)$. No ambiente controle foi encontrada maior frequência respiratória $\left(65 \mathrm{mov} \mathrm{min}^{-1}\right)$ em relação ao climatizado (65 mov. $\left.\mathrm{min}^{-1}\right)$ ( $\left.P>0,05\right)$. A frequência respiratória apresentaram correlações baixas e não significativas em relação a cama, concreto e o telhado.

Os períodos do dia influenciaram as temperaturas superficiais, enquanto os ambientes não interferiram nas temperaturas superficiais dos leitões. As temperaturas superficiais dorsais, pernil, pata, focinho, cabeça e ocular apresentaram correlação positiva com a temperatura superficial da cama. $O$ piso de concreto apresentou correlações positivas para todas as temperaturas superficiais avaliadas enquanto o telhado apenas para o pernil $(P<0,05$; Tabela 7).

Tabela 7-Correlações entre temperaturas superficiais corporais de leitões mantidos em baias livres de gaiolas e temperatura superficial de estruturas das instalações obtidas com câmera termográfica

\begin{tabular}{cccc}
\hline Temperatura Superficial & Cama & Concreto & Telhado \\
\hline Dorsal & $0,47^{*}$ & $0,50^{*}$ & 0,28 \\
Ventral & $0,30^{*}$ & $0,62^{*}$ & 0,29 \\
Pernil & $0,54^{*}$ & $0,76^{*}$ & $0,43^{*}$ \\
Pata & $0,39^{*}$ & $0,56^{*}$ & 0,25 \\
Focinho & $0,45^{*}$ & $0,56^{*}$ & 0,28 \\
Cabeça & $0,49^{*}$ & $0,66^{*}$ & 0,28 \\
Ocular & $0,52^{*}$ & $0,41^{*}$ & 0,23 \\
\hline
\end{tabular}




\subsubsection{Preferência Ambiental}

Em resultado geral, o lado de maior preferência das fêmeas foi o esquerdo, seguido pelo direito, na frente, atrás e no meio da baia $(P<0,01$; Tabela 8$)$.

Tabela 8- Demonstrativo das médias de preferência ambiental geral pelas fêmeas em relação aos locais dentro das baias individuais livres de gaiolas

\begin{tabular}{ccc}
\hline Lados & Preferência ambiental geral & $\operatorname{Pr}>|\mathbf{t}|$ \\
\hline Atrás (cama) & $9,40 \pm 1,31$ & 0,01 \\
Direita (ventiladores) & $31,6 \pm 1,95$ & 0,01 \\
Esquerda (bebedouros) & $40,3 \pm 2,05$ & 0,01 \\
Frente (área úmida e molhada) & $11,2 \pm 1,35$ & 0,01 \\
Centro (cama e enriquecimentos) & $4,80 \pm 0,98$ & 0,01 \\
\hline
\end{tabular}

Fonte: Própria autoria

O ambiente influenciou a escolha das fêmeas pelos locais dentro das baias $(P<0,05)$. No ambiente controle, de manhã, o lado esquerdo foi escolhido como preferido para as fêmeas, seguido pelo direito, atrás, na frente e no meio. A tarde, o local preferido continuou o esquerdo, seguido pelo direito, com inversão de preferência entre os locais na frente e atrás em relação ao período da manhã, com a área do meio continuando como a menos procurada. No ambiente climatizado, de manhã, o lado preferido escolhido pelas fêmeas foi o esquerdo, seguido pelo direito, atrás, no meio e na frente. A tarde, foram escolhidos os lados esquerdo, direito, na frente, atrás e no meio (Tabela 9).

O lado de traz da baia não diferiu entre os horários do dia $(P>0,05)$, mas foram diferentes quando os ambientes foram comparados, sendo preferido pelas porcas no horário da manhã $(P>0,01)$. As porcas preferiram a sombra em relação ao sol $(76,4 \%)(P<0,01)$.

Tabela 9-Preferência ambiental das fêmeas em relação aos períodos do dia e aos ambientes controle e climatizado

\begin{tabular}{ccccc}
\hline \multirow{2}{*}{ Lados da baia } & \multicolumn{2}{c}{ Ambiente Controle } & \multicolumn{2}{c}{ Ambiente Climatizado } \\
\cline { 2 - 5 } & Manhã & Tarde & Manhã & Tarde \\
\hline Atrás (cama) & $11,1 \pm 2,28 \mathrm{Ab}$ & $10,0 \pm 2,63 \mathrm{Ac}$ & $12,8 \pm 2,50 \mathrm{Ab}$ & $4,70 \pm 2,07 \mathrm{Bc}$ \\
Direita (ventiladores) & $33,8 \pm 3,44 \mathrm{Aa}$ & $30,0 \pm 4,01 \mathrm{Bb}$ & $26,6 \pm 3,28 \mathrm{Aa}$ & $37,1 \pm 4,71 \mathrm{Ba}$ \\
Esquerda (bebedouros) & $40,2 \pm 3,56 \mathrm{Aa}$ & $37,9 \pm 4,27 \mathrm{Ba}$ & $38,5 \pm 3,63 \mathrm{Aa}$ & $44,7 \pm 4,85 \mathrm{Ba}$ \\
Frente (área úmida e molhada) & $9,50 \pm 2,13 \mathrm{Ab}$ & $20,0 \pm 3,50 \mathrm{Bb}$ & $9,40 \pm 2,19 \mathrm{Ab}$ & $8,50 \pm 2,73 \mathrm{Ab}$ \\
Centro (cama e enriquecimentos) & $4,70 \pm 1,55 \mathrm{Ac}$ & $2,30 \pm 1,31 \mathrm{Bc}$ & $10,0 \pm 2,24 \mathrm{Ab}$ & $4,76 \pm 2,07 \mathrm{Bc}$
\end{tabular}

a,b,c A,B Letras maiúsculas diferentes na linha e letras minúsculas diferentes na coluna, para a mesma característica, diferem entre si pelo teste t a 5\%. Fonte: Própria autoria

A frequência respiratória das fêmeas foi maior no período da tarde $\left(54,6 \mathrm{mov}^{\mathrm{min}}{ }^{-1}\right)$ em relação a manhã (48 mov.min $\left.{ }^{-1}\right)(P>0,05)$. O ambiente controle apresentou 62 mov. $\mathrm{min}^{-1}$ 
enquanto que no ambiente climatizado 41 mov. $\min ^{-1}(P<0,01)$. A frequência respiratória apresentou correlação moderada com o dorso $(r=0,312)$ e com o focinho $(r=0,350 ; P<0,05)$. $\mathrm{Na}$ relação com as instalações, foram encontradas correlações positivas com o telhado ( $r=$ $0,487 ; P<0,05)$ e com a temperatura interna do ambiente $(r=0,353 ; P<0,05)$.

O período do dia influenciou a frequência respiratória dos leitões, com maiores médias

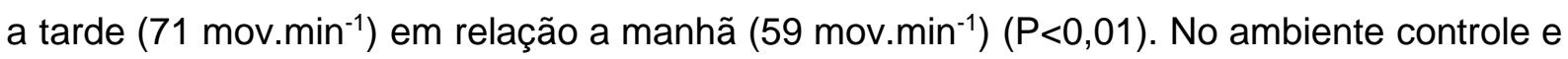
no climatizado a frequência respiratória foi a mesma (65 mov. $\left.\mathrm{min}^{-1}\right)(P>0,05)$.

As temperaturas superficiais corporais das fêmeas foram maiores no período da tarde $(P>0,05)$ e maiores no ambiente controle $(P>0,05)$.

Foram encontradas correlações positivas e significativas em relação a cama e as temperaturas superficiais do dorso, ventre, glândula mamária, pernil, cabeça e olhos. Em relação ao piso de concreto foram observadas correlações positivas $(P<0,05)$ em relação às regiões do dorso, ventre, glândula mamária, pernil, pata, focinho, cabeça e olhos (Tabela 11). As temperaturas dorsais, ventrais, do pernil, pata e vaginal apresentaram correlação positiva com a temperatura superficial do telhado ( $P<0,05$; Tabela 10).

Em relação às instalações, os horários de avaliação e os ambientes (climatizado e controle) influenciaram apenas as temperaturas superficiais do telhado, com temperaturas maiores no período da tarde e no ambiente controle.

Foram encontradas correlações positivas em relação a cama $(r=0,28 ; P<0,05)$ e 0 concreto $(r=0,26 ; P<0,05)$ com a temperatura interna. Entretanto para a umidade interna foram encontradas negativas para a cama $(r=-0,28 ; P<0,05)$ e o concreto $(r=-0,21 ; P<0,05)$.

Tabela 10- Correlações entre temperaturas superficiais corporais de fêmeas mantidas em baias livres de gaiolas e temperatura superficial de estruturas das instalações obtidas com câmera termográfica

\begin{tabular}{cccc}
\hline Temperatura Superficial & Cama & Concreto & Telhado \\
\hline Dorsal & $0,62^{*}$ & $0,69^{*}$ & $0,44^{*}$ \\
Ventral & $0,54^{*}$ & $0,66^{*}$ & $0,39^{*}$ \\
Glândula mamária & $0,63^{*}$ & $0,53^{*}$ & 0,22 \\
Pernil & $0,58^{*}$ & $0,72^{*}$ & $0,41^{*}$ \\
Pata & $0,50^{*}$ & $0,63^{*}$ & $0,44^{*}$ \\
Focinho & 0,48 & $0,52^{*}$ & 0,26 \\
Cabeça & $0,35^{*}$ & $0,57^{*}$ & 0,33 \\
Vaginal & 0,37 & 0,49 & 0,08 \\
Ocular & $0,41^{*}$ & $0,66^{*}$ & 0,45 \\
\hline
\end{tabular}

$\mathrm{P}<0,05^{\star}$. Fonte: Própria autoria

\subsection{Discussão}

\subsubsection{Análise Etológica}


Neste estudo, o comportamento de ócio foi unanimemente maior em todos os períodos e ambientes avaliados, mostrando a ausência de atividade dos animais dentro das baias. Com menor temperatura do ambiente climatizado às 7 horas $\left(22,1^{\circ} \mathrm{C}\right)$ as fêmeas preferiram este período para permanecer em ócio, enquanto os leitões preferiram o período da tarde (13 horas), também com menor temperatura no ambiente climatizado em relação ao controle $(24,5$ ${ }^{\circ} \mathrm{C} ; 26,2^{\circ} \mathrm{C}$ ) respectivamente. Na fase de maternidade, devido a amamentação, as fêmeas tendem a permanecer maior tempo em decúbito lateral e por estarem alojadas em sistema de semiconfinamento, sem acesso a piquetes, isto pode torna-se fator de relação, uma vez que em piquetes os animais tem a oportunidade de explorar o ambiente, construir de ninhos, ao final da gestação, que são definidos como comportamentos inatos e importantes ao bem-estar dos suínos.

De acordo com os resultados, maiores médias de ócio foram encontradas no ambiente climatizado, para fêmeas e leitões, sendo que a menor temperatura dos ambientes influenciou diretamente, trazendo maior conforto térmico as fêmeas e levando os leitões ao escamoteador, área restrita aos lactentes e propicia ao ócio melhorando o bem-estar dos suínos. Estes saiam apenas com os chamados realizados pelas fêmeas para amamentação.

Em ambientes não estimuladores, o comportamento apático é observado pela inatividade em excesso, indicando que o animal apresenta dificuldade em lidar com o ambiente em que está inserido (BROOM, 1991). Em sistemas de confinamento intensivo de produção comumente há uma inviabilidade da expressão do repertório etológico dos suínos, uma vez que o ambiente é, na realidade, estéril e com poucos estímulos ambientais, acarretando um direcionamento do seu comportamento investigatório para o ambiente onde está inserido ou aos outros animais presentes nas baias (MACHADO FILHO; HÖTZEL, 2000).

O comportamento estereotipado foi encontrado em baixa frequência neste estudo e com maiores apresentações no ambiente controle com provável explicação relacionada a presença de cama de bagaço de cana nas baias, que é tido como um dos principais enriquecimentos ambientais que podem ser utilizados para suínos, ao uso de correntes penduradas nas instalação e a temperatura mais alta quando comparada ao ambiente climatizado. Suínos demonstram maior motivação para interagir com objetos que sejam mastigáveis, deformáveis e destrutíveis, características associadas com substratos próprios para exploração e manipulação pelos animais (VAN DE WEERD; DAY, 2009). Os enriquecimentos mais eficientes, de acordo com os benefícios para os animais, em relação a entretenimento, são as camas de palha ou maravalha, os substratos (terra, areia, compostagens), madeira, forragem, tecidos e cordas, borracha e plástico, bloco mineral e objetos de metal (BRACKE et al., 2006).

Quando alojados em ambientes monótonos, áridos, com ausência de substratos são observados comportamentos anômalos, decorrentes da frustração gerada pela não 
adaptação ao ambiente (LOPES, 2004; RADOSTITS et al., 2002), podendo ainda, a espécie suína, em particular, alterar seu comportamento natural em um ambiente de onde não haja conforto térmico (KIEFER et al., 2009; RADOSTITS et al., 2002). Avaliando o comportamento de fêmeas suínas na maternidade a partir da inserção de ventiladores e aspersores de água no telhado utilizados como enriquecimento ambiental, Dela Ricci et al. (2012) encontraram maiores apresentações de comportamento estereotipado na ausência de enriquecimento ambiental. Quando confinados em baias ou presos por longo período, certos indivíduos tendem a apresentar comportamentos estereotipados, enquanto outros se tornam apáticos ou inativos (BROOM, 1981) demonstrando bem-estar animal pobre.

A apresentação deste transtorno pode ser maior ou menor e será conforme o tempo de permanência das fêmeas na maternidade, do tipo e da ambiência da instalação utilizada para alojamento dos animais. Da mesma forma, o confinamento intensivo a partir de gaiolas reduz a mobilidade das fêmeas, ocasionando estresse crônico, comprometendo o bem-estar das matrizes lactantes (BROOM, 1991).

Neste estudo, observou-se que as fêmeas e os leitões preferiram o período da manhã para explorar o ambiente, independente do ambiente avaliando, provavelmente devido a limpeza das baias, troca da cama de bagaço de cana e contato com os funcionários, confirmando que este comportamento é inato e importante a espécie suína. Suínos possuem um amplo aspecto comportamental, com alta capacidade de aprendizado (KILGOUR; DALTON, 1984) e sentidos bem desenvolvidos. Segundo Riesenberg et al. (2011) o comportamento exploratório é típico da espécie suína devido sua alta curiosidade pelo ambiente, fuçando ou investigando a baia, os objetos e até mesmo os outros indivíduos. Suínos em ambientes seminaturais, mantem-se, diariamente, $52 \%$ do tempo fuçando ou pastando e outros 23\% investigando o ambiente (BAPTISTA et al., 2011). Suínos desenvolvem ações de olhar, cheirar, lamber, fuçar e mastigar objetos como perfil exploratório (MAIA et al., 2013) e a partir do surgimento de problemas comportamentais quando existe incompatibilidade entre o instinto suíno e o ambiente em que este permanece alojado.

A maternidade de suínos apresenta necessidades térmicas específicas para leitões e porcas, uma vez que os leitões necessitam de uma temperatura maior, enquanto que a fêmea precisa de menor temperatura, tornando-se um desafio para a produção (TOLON; NAAS, 2005). No dia do nascimento a temperatura mínima para os leitões é de $30^{\circ} \mathrm{C}$ e a máxima de $32^{\circ} \mathrm{C}$ no dia do nascimento, chegando a mínima de $24^{\circ} \mathrm{C}$ e a máxima de $26^{\circ} \mathrm{C}$ na terceira semana após o nascimento (FERREIRA, 2005; PANDORFI et al., 2007). Neste estudo, os leitões mamaram mais no ambiente controle, podendo ser uma explicação o fato de que neste ambiente as temperaturas estão mais próximas e dentro das médias ideais de conforto térmico dos leitões. 
O comportamento de beber foi mais observado em fêmeas suínas e leitões no ambiente controle, com temperaturas mais altas em relação ao climatizado. Leitões procuraram mais o bebedouro no período da tarde, enquanto as fêmeas no período da manhã, podendo estar relacionado a maior atividade de exploração das fêmeas no período da manhã. Ainda, pelas fêmeas o comportamento de beber apresentou uma segunda função além da fisiológica, a da distração, descrita pela procura pelos bebedouros buscando diminuir a temperatura corporal ou por atividade lúdica. O comportamento lúdico em baixa frequência de apresentação, demonstra que o bem-estar é pobre (BROOM; MOLENTO, 2004).

Neste estudo, o comportamento lúdico foi apresentado por leitões no ambiente climatizado e de manhã. Em relação as fêmeas, este comportamento foi mais verificado de manhã e no ambiente controle. Este resultado pode estar relacionado a melhora da temperatura ambiental resultante da inserção dos ventiladores e aspersores, já que em ambos os ambientes havia a presença de enriquecimentos ambientais de corrente e as fêmeas possuíam interação com seus leitões. Segundo o Comitê Científico Veterinário da Comissão Europeia, fêmeas suínas têm preferência em manter contato social com outros suínos, demonstrando maior frequência de comportamentos lúdicos em relação à agressividade (STEVENSON, 2000). Suínos inseridos em ambientes com alta temperatura permanecem mais próximos ao bebedouro, apresentando maior ingestão de água, com menor consumo de alimentos e diminuição da atividade de permanecer em pé, que podem influenciar no desempenho dos leitões (KIEFER et al., 2009).

\subsubsection{Preferência Ambiental}

No lado definido como esquerdo da baia foram instalados os bebedouros, o qual, além de atender às exigências fisiológicas, era pressionado, repetidamente, pelo focinho das porcas, a fim de que a lâmina de água molhasse o piso, sendo uma possível explicação para a maior preferência em permanecer do lado esquerdo. Essa situação permitiu a troca de calor por condução, uma vez que a água possui maior condutividade térmica que o ar (GUYTON; HALL, 2002). Segundo Laganá (1998), o resfriamento do piso das baias com água reduz o estresse térmico de suínos, uma vez que é da natureza da espécie deitar em locais com água na tentativa de perder calor para o solo.

A preferência pelo lado direito pode ser atribuída ao fato de que o vento, proveniente do ventilador, melhor se propagava nesta direção, permitindo a troca de calor por convecção, podendo proporcionar uma amplitude térmica ambiental na faixa de 1 a $3^{\circ} \mathrm{C}$ (AXAOPOULOS et al., 1992).

Durante o período da tarde, onde foram encontradas maiores temperaturas ambientais, as porcas do ambiente climatizado preferiam permanecer na área da frente das 
baias devido a presença da água oriunda do aspersor localizado no telhado, que caia sobre o piso cimentado, sem cama. No ambiente controle também foi observada maior preferência pelo lado da frente, no período da tarde, podendo estar relacionada a lavagem e retirada dos desejos realizada neste local, permanecendo, nos primeiros horários da manhã e à tarde o piso umedecido (área úmida). A opção pela área da frente da baia reduz a temperatura corporal das fêmeas ocasionando melhor conforto térmico e é permitida pela retirada das gaiolas da fase de maternidade.

O local descrito como atrás possui cobertura no piso de cama com bagaço de cana o que ocasiona aumento na temperatura corporal dos suínos, fazendo com o que o animal prefira a parte da frente onde não há cama apenas o piso concretado e molhado no ambiente climatizado pelo aspersor. Esse resultado corrobora com os encontrados por Fraser (1985) e Souty et al. (1978), cujo os efeitos positivos, dos alojamentos com cama em baias abertas em suínos de crescimento, foram observados em condições com temperaturas abaixo de $10^{\circ} \mathrm{C}$ (frias) devido a diminuição do limite de temperatura pelo efeito tampão da cama. Para Warriss (1996), é recomendado que se evite a utilização de cama de palha quando a temperatura for maior que $20^{\circ} \mathrm{C}$ para evitar o estresse por calor, substituindo por areia molhada ou maravalha a fim de manter os animais em conforto térmico.

Assim como o lado atrás possuía cobertura de cama, o meio da baia recebia parte da cama e parte permaneceu sem cobertura. No entanto, neste local, foram observados comportamentos dos leitões, como ócio, exploratórios, lúdicos e amamentação. Notadamente, este local foi menos procurado pelas fêmeas devido a esta presença constante dos leitões em relação a outros locais.

Em relação as temperaturas superficiais corporais obtidas com a câmera termográfica, maiores temperaturas foram encontradas a tarde e no ambiente controle, possivelmente relacionadas a maior temperatura do ambiente e dos horários de avaliação. As instalações não possuem medidas adequadas para a criação de suínos, com pé direito abaixo do preconizado $(2,70 \mathrm{~m})$, com muretas baixas $(1,65)$ e sem janelas para visualização entre suínos nas baias ao lado. Isso pode ter influenciado a frequência respiratória ser correlacionada positivamente com os pisos e o telhado avaliados em relação aos leitões e correlações positivas entre os pisos, telhado e a temperatura interna para as fêmeas.

Em relação as instalações, o telhado apresenta-se em altura não recomendada para uma ventilação adequada a criação de suínos, mesmo construídos por telhas de barro e ripas de madeira. Segundo Furtado et al. (2003) as telhas de barro oferecem melhor conforto quando comparadas a telha de cimento amianto, por exemplo. O telhado, neste estudo, apresentou efeito de horários, estação do ano e ambientes, demonstrando a importância da cobertura para o conforto térmico de matrizes e leitões. Em instalações de confinamento de 
animais, o telhado tem função primária na determinação de trocas térmicas, especialmente, em regiões tropicais (TURNPENNY et al., 2000).

As fêmeas preferiram a sombra, dentro das instalações em relação ao sol. Suínos, são animais que, quando em vida livre, exploram o ambiente, tomando banho de sol em horários de temperaturas amenas, principalmente devido a prevenção de avitaminoses. No entanto, na suinocultura intensiva, o sol é normalmente evitado, com instalações construídas com o seu eixo longitudinal orientado no sentido Leste-Oeste, para que as sombras incidam em embaixo da cobertura e a carga térmica recebida pela instalação seja menor possível. Mesmo em instalações adequadamente construídas, ocorrerá a incidência direta de radiação solar no interior em determinadas horas do dia na face norte, no período de inverno. Para prevenir, é necessário providenciar nessa face proteção para evitar essa incidência solar (Embrapa, 2003), buscando evitar altos aquecimentos dentro das instalações.

\subsubsection{Conclusão}

O ambiente climatizado diminuiu as mamadas devido a menor temperatura, abaixo da zona de conforto dos leitões, porém, houve aumento da apresentação de comportamentos lúdicos e exploratórios, importantes à espécie. Fêmeas mantidas em instalações livres de gaiolas procuram por diferentes áreas dentro das baias, apresentando comportamentos naturais e possibilitando melhor bem-estar, destacando-se com este estudo, a importância da climatização ambiental para as criações de suínos com a elucidação dos efeitos da inserção de equipamentos simples e práticos que aliados à ausência das gaiolas permitem a melhoria do bem-estar de suínos em confinamento. 


\section{Referências}

AXAOPOLOS, P.; PANAGAKIS, P.; KYRITSIS, S. Computer simulation assessment of the thermal microenvironment of growing pigs under summer conditions. Transactions of the American Society of Agricultural and Biological Engineers, St. Joseph, v. 35, p. 10059,1992 .

BAPTISTA, R. I. A. A.; BERTANI, G. R.; BARBOSA, C. N. Indicadores do bem-estar em suínos. Ciência Rural, Santa Maria, v. 41, p. 1823-1830, 2011.

BRACKE, M. B. M. et al. Formalised review of environmental enrichment for pigs in relation to political decision making. Applied Animal Behaviour Science, Amsterdam, v. 98, p. 165182, 2006.

BROOM, D. Animal welfare: concepts and measurements. Journal of Animal Science, Champaign, v. 69, p. 4167-4175, 1991.

BROOM, D. M.; MOLENTO, C. F. M. Bem-estar animal: conceitos e questões relacionadas Revisão. Archives of Veterinary Science, Curitiba, v. 9, p. 1-11, 2004.

CAMPOS, J. A. et al. Enriquecimento ambiental para leitões na fase de creches advindos de desmame aos 21 e 28 dias. Revista Brasileira de Ciências Agrárias, Recife, v. 5, p. 272278, 2010.

DELA RICCI, G. et al. Análise do comportamento de matrizes suínas lactantes com o uso de enriquecimento ambiental na maternidade. In: JORNADA DE INICIAÇÃO CIENTÍFICA EMBRAPA, 6., 2012, Concórdia. Anais... Concórdia, 2012, p. 32-67.

DEL-CLARO, K. Comportamento animal: uma introdução à ecologia comportamental. São Paulo: Conceição, 2004.

DUNCAN, I. J. H.; FRASER, D. Understanding animal welfare. In: APPLEBY, M. C.; HUGHES, B. O. Animal welfare. London: Cab International, 1997. cap. 3, p. 19-31.

FERREIRA, F. M. et al. Comportamento de monta e características seminais de suínos jovens Landrace e Large White. Ciência Rural, Santa Maria, v. 35, p. 131-137, 2005.

FRASER, D. Selection of bedded and unbedded areas by pigs in relation to environmental temperature and behaviour. Applied Animal Behaviour Science, Amsterdam, v. 14, p. 117126, 1985.

FRASER, A. F.; BROOM, D. M. Farm animal behaviour and welfare. London: Ballière Tindall, 1990.

GUYTON, A. C.; HALL, J. E. Tratado de fisiologia médica. Rio de Janeiro: Guanabara Koogan, 2002.

GRANDIN, T.; JOHNSON, C. Bem-estar dos animais. São Paulo: Rocco, 2009.

KIEFER, C. et al. Resposta de suínos em crescimento mantidos em diferentes temperaturas. Archivos de Zootecnia, Cordoba, v. 58, n. 221, p. 55-64, 2009.

KILGOUR, R.; DALTON, S. Livestock Behaviour. London: Grana, 1984. 
KOPPEN. Clima dos Municípios Paulistas. 2018. Informações sobre o Clima- Campinas, São Paulo. Disponível em: <http://www.cpa.unicamp.br/outras-informacoes/clima-dosmunicipios-paulistas.html>. Acesso em: 20 ago. 2018.

LAGANÁ, C.; NÄÄS, I. A.; TOLON, Y. B. Lámina de agua em corrales de gestación para suinos. Agrociência, Texcoco, v. 14, p. 79-83, 1998.

LEWIS, N. J. Frustration of goal-directed behaviour in swine. Applied Animal Behaviour Science, Amsterdam, v. 64, p. 19-29, 1999.

LOPES, E. J. C. Análise do bem-estar e desempenho de suínos em sistema de cama sobreposta. 2004. 111 f. Dissertação (Mestrado) - Universidade Federal de Santa Catarina, Florianópolis, 2004.

MAIA, A. P. et al. Enriquecimento ambiental como medida para o bem-estar positivo de suínos. Revista Eletrônica em Gestão, Santa Maria, v. 14, p. 2862-2877, 2013.

MACHADO FILHO, L. C. P.; HÖTZEL, M. J. Bem-estar dos suínos. In: SEMINÁRIO INTERNACIONAL DE SUINOCULTURA, 5., 2000, São Paulo. Anais... São Paulo: Gessuli, 2000. p. 70-82.

MARTIN, P.; BATESON, P. Measuring behavior: an introductory guide. Cambridge: Cambridge University Press, 1993.

PANDORFI, $H$. et al. Uso da lógica fuzzy na caracterização do ambiente produtivo para matrizes gestantes. Engenharia Agrícola, Jaboticabal, v. 27, p. 83-92, 2007.

PINHEIRO, J.V. A pesquisa com bem estar animal tendo como alicerce o enriquecimento ambiental através da utilização de objeto suspenso no comportamento de leitões desmamados e seu efeito como novidade. $2009.65 \mathrm{f}$. Dissertação (Mestrado), Faculdade de Medicina Veterinária e Zootecnia, Universidade de São Paulo, São Paulo, 2009.

POLETTO, R. Bem-estar animal. Suíno.com, Tangará, 5 abr. 2010. (Série especial bemestar animal por Rosangela Poletto). Disponível em: <http://tinyurl.com/4t6z4bk>. Acesso em: 03 jul. 2018.

RADOSTITS, O. M. et al. Clínica veterinária: um tratado de doenças dos bovinos, ovinos, suínos, caprinos e equinos. Rio de Janeiro: Guanagra Koogan, 2002.

RIESENBERG, A. A. et al. Enriquecimento ambiental na forma de brinquedos para leitões após o desmame. Disponível em: http://www.agraria.pro.br/ojs-

2.4.6/index.php?journal=agraria\&page=article\&op=view\&path\%5B\%5D=agraria_v5i2a660>. Acesso em: 30 abr. 2013.

SARUBBI, J. Bem-estar dos animais e uso racional de energia elétrica em sistemas de aquecimento para leitões desmamados. 2009. 119 f. (Mestre) - Faculdade de Engenharia Agrícola, Universidade Estadual de Campinas, Campinas, 2009.

SARUBBI, J. Bem estar animal não se restringe às instalações e equipamentos: o uso de novas tecnologias. In: FÓRUM INTEGRAL DE SUINOCULTURA: TEORIA E PRÁTICA DO BEM ESTAR ANIMAL NA PRODUÇÃO DE SUÍNOS, 1., 2011, Curitiba. Anais... Curitiba. 2011. p. 36-50. 
SOBESTIANSKY, J. et al. Formas anormais de comportamento dos suínos: possíveis causas e alternativas de controle. Concórdia: Embrapa CNPSA, 1991. 29 p. (Circular Técnica, 14).

SOMMAVILLA, R. Comportamento e bem-estar de animais zootécnicos. 2008. $69 \mathrm{f}$. (Estágio Curricular Obrigatório) - Centro de Ciências Agroveterinárias, Universidade do Estado de Santa Catarina, Lages, 2008.

SNOWDON, C. T. O significado da pesquisa em comportamento animal. Estudos de Psicologia, Campinas, v. 4, p. 365-373, 1999.

STEVENSON, P. Questões de bem-estar animal na criação intensiva de suínos na União Européia. Em: CONFERÊNCIA VIRTUAL INTERNACIONAL SOBRE QUALIDADE DE CARNE SUÍNA, 3., 2000. Concórdia. Anais... Concórdia. Embrapa Suínos e Aves, 2000. p. 4-10. (Documento, 69).

SOUTY, J. C.; MARTINOT, R.; LOUTREL, P. Les porcheries sur litidre accumul6e pour l'engraissement. IDeep-litter housing in pig fattening unitsl. Journees de la Recherche Porcine en France, Paris, v. 10, p. 323-332, 1978.

TAROU, L. R.; BASHAW, M. J. Maximizing the effectiveness of environmental enrichment: Suggestions from the experimental analysis of behaviour. Applied Animal Behaviour Science, Amsterdam, v. 102, p. 189-204, 2007.

TOLON, Y. B.; NAAS, I. A. Avaliação de tipos de ventilação em maternidade de suínos. Engenharia Agrícola, Jaboticabal, v. 25, p. 565-574, 2005.

VAN DE WEERD, H. A. et al. A systematic approach towards developing environmental enrichment for pigs. Applied Animal Behaviour Science, Amsterdam, v. 84, p. 101-118, 2003.

VAN DE WEERD, H. A.; DAY, J. E. A review of environmental enrichment for pigs housed in intensive housing systems. Applied Animal Behaviour Science, Amsterdam, v. 116, p. 120, 2009.

WARRISS, P. D. The consequences of fighting between mixed groups of unfamiliar pigs before slaughter. Meat Focus Internation, Wallingford, v. 4, p. 89-92, 1996. 


\section{TERMOGRAFIA INFRAVERMELHA COMO MÉTODO NÃO INVASIVO PARA AVALIAÇÃO DE ESTRESSE POR CALOR EM SUÍNOS MANTIDOS EM BAIAS LIVRES DE GAIOLAS NA MATERNIDADE}

\section{Resumo}

A termografia é um método não invasivo de análise de temperatura corporal superficial em suínos. Este estudo teve como objetivo avaliar a temperatura corporal de fêmeas e leitões mantidos em baias individuais livre de gaiolas com a utilização da termografia infravermelha. O estudo foi conduzido durante o verão e o outono no setor de suinocultura da USP, em Pirassununga, Brasil. Foram avaliadas 26 fêmeas e 281 leitões. Na área climatizada foram inseridos ventiladores e aspersores de água no telhado. As colheitas de dados foram realizadas com intervalos de sete dias, nos períodos manhã e tarde com colheita de saliva para determinação do cortisol realizada para porcas. A temperatura de superfície corporal foi realizada nas porcas e aleatoriamente em cinco leitões por leitegada utilizando câmera termográfica. As imagens da câmera termográficas foram analisadas utilizando o software IRSoft Version 3.6 Testo. Foi incluído efeito fixo de climatização, período e estações e suas interações, além de correlações de Person. No verão e no outono, a área superficial mais quente das fêmeas foi a glândula mamária e a mais fria a vaginal. Para os leitões a área mais quente no verão foi a cabeça e a mais fria o focinho. A estação influenciou as temperaturas da cama, piso e telhado. Foram encontradas correlações positivas para a cama, concreto e

telhado com a temperatura interna. A frequência respiratória das fêmeas apresentou correlação positiva com o dorso e focinho, enquanto para os leitões correlacionou-se com a cama, concreto e telhado. Conclui-se que à utilização de termografia permite identificar as áreas superficiais mais quentes e frias dos suínos em diferentes ambientes indicando melhorias nas instalações que melhorem o bem-estar na fase de maternidade.

\subsection{Introdução}

Suínos possuem dificuldade de adaptação a ambientes com temperaturas elevadas, devido ao seu metabolismo elevado, sistema termorregulador pouco desenvolvido, capa de tecido adiposo subcutânea espessa e a queratinização das glândulas sudoríparas, que prejudicam a perda por sudorese de calor (RODRIGUES et al., 2010). Em estresse por calor, devido ao aumento da temperatura ambiente, em criações intensivas, há aumento da excreção do cortisol (STARLING et al., 2005), originando alterações no metabolismo, com consequências importantes no comportamento e bem-estar (SILANIKOVE, 2000). 
Modificações do ambiente melhoraram o bem-estar dos animais, satisfazendo necessidades comportamentais e fisiológicas (BRACKE et al., 2006). O uso de baias sem gaiolas para as matrizes auxilia na termorregulação, com a possibilidade de modificação da postura e escolha por áreas área mais confortáveis. Em regiões com temperaturas ambientais elevadas, há necessidade de climatização, como a inserção de ventiladores e aspersores de água, que melhoram o conforto térmico de suínos em confinamento (DELA RICCI et al., 2018).

Buscando avaliar o nível de conforto e bem-estar dos animais em sistemas de confinamento, tem-se utilizado tecnologias práticas e de fácil aplicação. A termografia surge, como método não invasivo (VERCELLINO et al., 2010), que permite análises com precisão da temperatura corporal (CALDARA et al., 2014), obtendo respostas térmicas importantes (PHILLIPS; HEATH, 2001), sem expor o animal a radiações (HOOGMOED; SNYDER, 2002), monitorando a atividade metabólica dos indivíduos por meio da temperatura superficial, com avaliações do fluxo de calor de maneira qualitativa e quantitativa (EDDY et al., 2001), além de diagnósticos antecipados de doenças (SCHAEFER et al., 2002) e de estresse por calor.

A técnica de termografia tem sido utilizada como uma prática eficaz para avaliar o conforto térmico de suínos em confinamento, demonstrando que as temperaturas superficiais são afetadas pela temperatura ambiente. Kotrbacek e Nau (1985) avaliando imagens termográficas, apontaram que nos últimos dias de gestação e especialmente após o parto, a temperatura da pele da glândula mamária representava a área superficial corporal mais quente, onde no primeiro dia de lactação, a temperatura superficial da glândula mamária foi de $39^{\circ} \mathrm{C}$ e nos períodos posteriores da lactação, a temperatura permaneceu entre 37 e $38^{\circ} \mathrm{C}$.

Diante da importância da avaliação de métodos que enriqueçam o ambiente e que mensurem o bem-estar de forma prática e não-invasiva aos suínos, este estudo foi elaborado com o objetivo de avaliar alterações na temperatura superficial de fêmeas mantidas em baias individuais livre de gaiolas e suas leitegadas, a partir da câmera termográfica, em ambientes climatizado por ventiladores e aspersores de água no telhado e não climatizado, buscando indicar métodos sustentáveis para melhoria do bem-estar dos suínos em fase de maternidade.

\subsection{Material e Métodos}

\subsubsection{Ambientes e Animais}

O estudo foi conduzido nas instalações de maternidade do Setor de Suinocultura da Prefeitura, na Universidade de São Paulo, Campus Fernando Costa, em Pirassununga, estado de São Paulo. O local encontra-se em altitude de 340 metros, latitude sul de $21^{\circ} 80^{\prime} 00^{\prime \prime}$ e longitude oeste de 47²5'42", clima Cwa com temperaturas anuais mínimas médias de 13 e máximas de $31^{\circ}$ Celsius, segundo Koppen (2011), com orientação da instalação no sentido norte-sul. O experimento foi realizado nas estações do verão e do outono. O presente trabalho 
foi aprovado pela Comissão de Ética no Uso de Animais № 3758260116 da Faculdade de Zootecnia e Engenharia de Alimentos da Universidade de São Paulo.

O sistema utilizado foi o de semiconfinamento com baias individuais para fêmea e leitegada com 1,80 m de largura, 4,20 m de comprimento, sem gaiolas, piso cimentado com cama, grade antiesmagamento de 3,20 m de comprimento, bebedouros tipo chupeta para fêmeas e leitões e comedouro tipo calha para leitões e de concreto para as fêmeas. Possui escamoteador com lâmpada para aquecimento dos leitões, separado da baia, por uma parede de 1,65 m de altura que permite acesso apenas dos lactentes a partir de uma abertura de 0,5 $\mathrm{m}$ de altura e 0,3 de largura. Cada baia possui duas correntes penduradas utilizadas como enriquecimento ambiental para ambas as idades (fêmeas e lactentes). A instalação possui pé direito de 2,70 m, telhado constituído por telhas francesas e madeira com piso de concreto.

A maternidade foi dividida em climatizada e controle. Nas baias experimentais climatizadas foram acrescidos ventiladores, da marca Ventisol de $60 \mathrm{~cm}$, três hélices, de potência 1/5CV - 147W; e 1200 rpm máxima. Foi utilizado um ventilador para cada duas fêmeas e suas respectivas leitegadas a $1,80 \mathrm{~m}$ do piso, fixados no pilar e um aspersor/ irrigador de pulso com haste da marca TRAPP - DY-1013 para molhar o telhado, fixados na mureta, sendo utilizados um aspersor para cada três fêmeas (baias).

A área controle era constituída por baias com cama de bagaço de cana, enriquecimentos ambientais e a mesma estrutura física da área climatizada, no entanto sem a presença de ventiladores e aspersores de água no telhado. Ambos os ambientes possuíam escamoteadores que permaneceram com suas lâmpadas acesas para os leitões durante todo o período experimental. As instalações foram separadas por lona plástica como forma de separar os ambientes, com a distância de 1,5 metros entre os tratamentos, impedindo circulação do ar dos ventiladores e umidade para o tratamento controle. Observa-se que houve controle das temperaturas, mostrando ambientes termicamente diferentes (Tabela 11).

Tabela 11- Temperaturas e umidades dos ambientes climatizado e controle de acordo com as estações do ano e horários de avaliação

\begin{tabular}{|c|c|c|c|c|c|c|c|c|}
\hline \multirow{3}{*}{ Ambiente } & \multicolumn{4}{|c|}{ Verão } & \multicolumn{4}{|c|}{ Outono } \\
\hline & \multicolumn{2}{|c|}{7 horas } & \multicolumn{2}{|c|}{13 horas } & \multicolumn{2}{|c|}{7 horas } & \multicolumn{2}{|c|}{13 horas } \\
\hline & $\mathrm{T}\left({ }^{\circ} \mathrm{C}\right)$ & Umidade & $\mathrm{T}\left({ }^{\circ} \mathrm{C}\right)$ & Umidade & $\mathrm{T}\left({ }^{\circ} \mathrm{C}\right)$ & Umidade & $\mathrm{T}\left({ }^{\circ} \mathrm{C}\right)$ & Umidade \\
\hline Climatizada & 23,3 & 79 & 26,2 & 86,7 & 21 & 84,9 & 22,9 & 84,8 \\
\hline Controle & 25,6 & 67,4 & 29,2 & 66 & 21,8 & 80,6 & 23,4 & 74,8 \\
\hline
\end{tabular}

Fonte: Própria autoria.

Em relação aos animais, foram utilizadas 26 fêmeas, Landrace $x$ Large White, e suas respectivas leitegadas, totalizando 281 leitões, sendo 154 fêmeas e 127 machos, com desmame aos vinte e um dias. Os animais foram vacinados, passaram por práticas rotineiras 
como mossagem australiana, desgaste dos dentes, corte de cauda e castração dos leitões machos, no segundo dia após o nascimento. O manejo nutricional era realizado de manhã e à tarde para fêmeas e leitões, com $7 \mathrm{~kg}$ ao dia para fêmeas e com aumento progressivo para os leitões, iniciando com 200 gramas na primeira semana e $500 \mathrm{~g}$ na semana do desmame.

\subsubsection{Análises fisiológicas de fêmeas suínas e leitões}

As colheitas de saliva para determinação do cortisol salivar das porcas foram realizadas com intervalos de sete dias, em dois horários distintos (7:00 horas e 13:00 horas), buscando horários com temperaturas mais amenas e mais quentes do dia, para verificar um possível efeito do ritmo diurno do cortisol nas fêmeas, iniciando com a primeira colheita no dia dois da fase de maternidade. As colheitas de dados ocorreram sempre nas baias onde os animais estavam alojados, sem necessidade de contenção manual ou mudança de local.

A colheita se deu individualmente, deixando a fêmea mastigar uma corda de algodão trançada de 5 a 10 minutos. Após a obtenção da saliva necessária $(1 \mathrm{ml})$, a corda de algodão foi prensada e as amostras de saliva armazenadas no Salivette ${ }^{\circledR}$, centrifugadas a 3500rpm por 30 minutos para uma limpeza das mesmas, e logo após os sobrenadantes foram enviados para análise em laboratório comercial para determinação do cortisol pelo método Eletroquímioluminescência (ESCRIBANO et al., 2012).

A frequência respiratória foi obtida de leitões e porcas em dois horários distintos (7:00 horas e 13:00 horas), buscando horários com temperaturas mais amenas e mais quentes do dia. Foram escolhidos, aleatoriamente, cinco animais da leitegada, em repouso. Em relação as porcas, todas foram avaliadas. A frequência respiratória foi obtida por observação visual direta e a contagem dos movimentos do flanco das porcas e leitões por 1 minuto, com auxílio de um cronômetro digital, nomeada como movimentos respiratórios por minuto (mov.min ${ }^{-1}$ ).

A temperatura retal foi colhida com termômetro digital foi de todas as porcas e para cinco leitões de cada leitegada (amostra) três vezes por semana, totalizando nove colheitas, nos horários das 7:00 e as 13:00 horas, iniciando com a primeira colheita no dia dois da fase de maternidade. As colheitas de dados ocorreram nas baias onde os animais estavam alojados, sem necessidade de contenção manual das porcas, com contenção dos leitões por dois manejadores sem mudança de local.

A obtenção dos dados a partir de fotos da câmera termográfica ocorreu em dois horários (7:00 horas e 13:00 horas), buscando horários com temperaturas mais amenas e mais quentes do dia, realizadas com intervalos de sete dias, totalizando seis análises por fêmea. A avaliação foi realizada com os animais secos e em diferentes posturas nas quais foram consideradas as posições: decúbito lateral direito, esquerdo, sentados ou em pé.

Para análise da temperatura de superfície corporal foram escolhidos aleatoriamente, três leitões por leitegada e todas as porcas. Em cada colheita foram registradas sete medidas 
pontuais em leitões e nove nas porcas, sendo: Temperatura Superficial Dorsal (TSD), Temperatura Superficial Ventral (TSV), Temperatura Superficial da Pata (TSP), Temperatura Superficial do Pernil (TSPN), Temperatura Superficial da cabeça (TSC), Temperatura Superficial do focinho (TSF) e Temperatura Superficial Ocular (TSO) com acréscimo da Temperatura Superficial da glândula mamária (TSGM) e vaginal (TSV) das porcas.

Para as mensurações foi utilizada uma câmera termográfica (Thermal imager TESTO $875 \AA$, Lenzkirch, Alemanha). O equipamento foi calibrado para uma emissividade de 0,98 indicado para tecidos biológicos, a distância de 1 metro de para o registro dos dados. As imagens termográficas das temperaturas ao longo da superfície corporal foram pontos em cada área escolhida aleatoriamente nas fotos (Figura 3).

Figura 3 - Demonstrativo das áreas corporais onde foram registrados imagens com a utilização da câmera termográfica em porcas e leitões
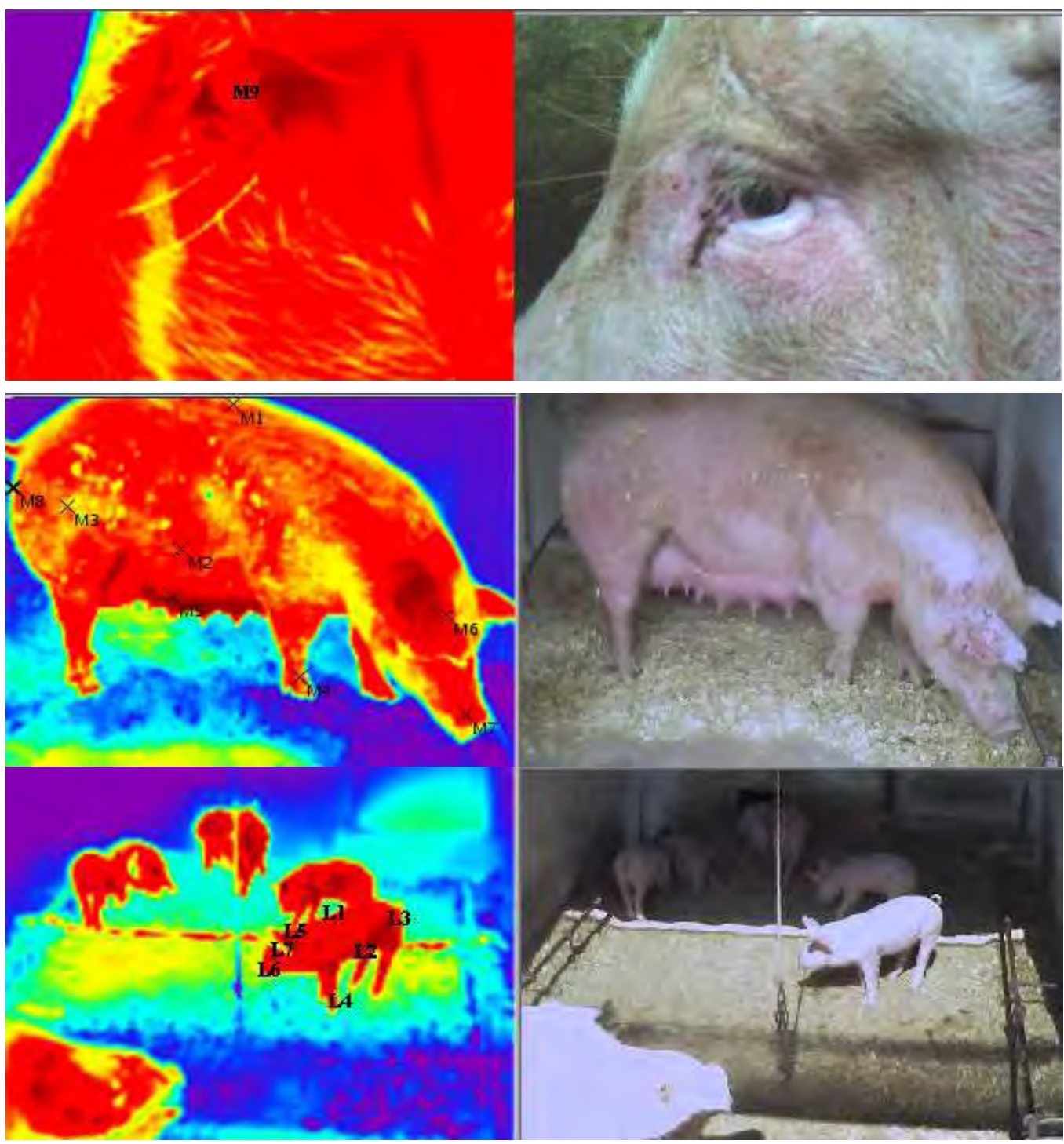

Fonte: Própria autoria. 
Foram aferidas as temperaturas do telhado, da cama de bagaço de cana e do piso de concreto, utilizando a câmera termográfica usando a emissividade de 0,95 indicada para estruturas. As imagens termográficas das temperaturas ao longo da superfície das instalações foram pontos em cada área escolhida aleatoriamente nas fotos (Figuras 3 e 4).

Os parâmetros meteorológicos: temperatura do ar, umidade relativa e a temperatura do globo negro foram registradas nas baias experimentais por meio de data logger (Onset $\mathrm{HOBO} \circledast \mathrm{TEMP} / \mathrm{RH} / 2$ ext channels) inseridos um para cada área (climatizada e controle) obtidas a cada 15 minutos, instalados no centro das baias a uma altura de 1,8 metros do solo para que os animais não tivesse acesso ao objeto. O dispositivo permaneceu no local durante todo o período experimental. As medidas de temperaturas ambientais e corporais foram obtidas e avaliadas simultaneamente. Os locais de obtenção dos registros com a câmera termográfica do telhado e dos pisos estão descritos e indicados na Figura 4.

Figura 4 - Demonstrativo das áreas da instalação da maternidade onde foram obtidos dados com a utilização da câmera termográfica
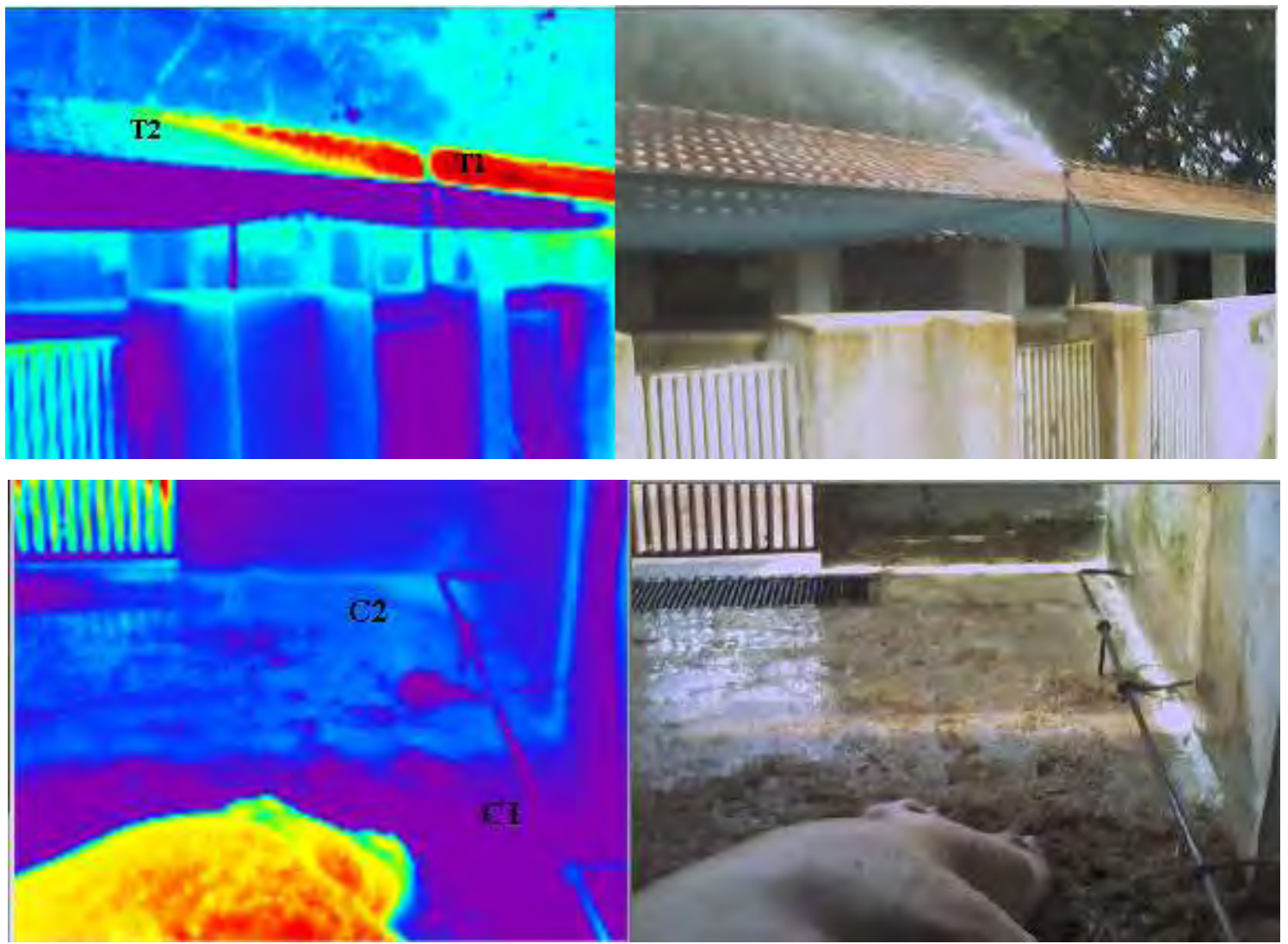

Fonte: Própria autoria

\subsubsection{Análise Estatística}

As imagens termográficas foram analisadas utilizando o software IRSoft Version 3.6 Testo Thermal Imagers para determinar temperatura máxima da área avaliada. Foram utilizadas fotos obtidas com a câmera, a partir de um histograma, pela paleta "Arco- Íris" para 
a obtenção de pontos nas áreas corporais e estruturais, com escala de temperatura de $21^{\circ} \mathrm{a}$ $40,5^{\circ} \mathrm{C}$. Os dados de temperatura superficial, temperatura retal e cortisol foram analisados com efeitos fixos de tratamento (climatizado e controle), estação do ano (verão e outono), período (manhã e tarde) e suas interações. As comparações das médias foram realizadas pelo teste F e t (PDIFF) utilizando o procedimento GLM do Software SAS (2017). Para relacionar os dados de termografia, temperatura superficial e o cortisol utilizou-se o coeficiente de correlação de Pearson. Um nível de probabilidade de $\mathrm{P}<0,05$ foi escolhido como limite para significância estatística em todos os testes. Considerando que, níveis de probabilidade de entre 5 e $7 \%$ foram considerados como uma tendência.

\subsection{Resultados}

\subsubsection{Instalação}

A estação do ano influenciou as temperaturas superficiais da cama, do concreto e telhado mensuradas com a câmera termográfica $(P \leq 0,05)$, com maiores médias encontradas para o verão em relação ao outono. Entretanto, os horários de avaliação e os ambientes (climatizado e controle) influenciaram apenas as temperaturas superficiais do telhado, com temperaturas maiores no período da tarde e no ambiente controle (Tabela 12).

Tabela 12-Temperaturas superficiais, em graus Celsius, dos pisos e telhado obtidas por meio da câmera termográfica das instalações da maternidade de baias livres de gaiolas seguidas dos erros padrões

\begin{tabular}{|c|c|c|c|c|c|c|c|c|c|}
\hline \multirow{2}{*}{ Instalação } & \multicolumn{2}{|c|}{ Hora } & \multicolumn{4}{|c|}{ Ambiente } & \multicolumn{2}{|c|}{ Estação } & \multirow[b]{2}{*}{$P>|t|$} \\
\hline & Manhã & Tarde & $P>|t|$ & Controle & Climatizado & $P>|t|$ & Verão & Outono & \\
\hline Cama & $26,2 \pm 0,51$ & $27,3 \pm 0,54$ & 0.14 & $26,6 \pm 0,52$ & $26,9 \pm 0,53$ & 0.67 & $27,8 \pm 0,53$ & $25,7 \pm 0,52$ & 0.05 \\
\hline Concreto & $25 \pm 0,66$ & $26,3 \pm 0,73$ & 0,20 & $25,2 \pm 0,69$ & $26,1 \pm 0,71$ & 0,38 & $27,5 \pm 0,71$ & $23,8 \pm 0,69$ & 0,03 \\
\hline Telhado & $29,5 \pm 0,86$ & $35,7 \pm 0,83$ & 0,01 & $38,3 \pm 0,83$ & $27,0 \pm 0,86$ & 0,01 & $36,6 \pm 0,74$ & $28,6 \pm 0,94$ & 0,01 \\
\hline
\end{tabular}

Fonte: Própria autoria

Foram encontradas correlações positivas em relação a cama $(r=0,28 ; P<0,05)$ e 0 concreto $(r=0,26 ; P<0,05)$ com a temperatura interna. Entretanto para a umidade interna foram encontradas negativas para a cama $(r=-0,28 ; P<0,05)$ e o concreto $(r=-0,21 ; P<0,05)$.

\subsubsection{Fêmeas suínas}

As estações do ano influenciaram as temperaturas superficiais corporais, enquanto, os ambientes climatizado e controle e os períodos do dia não influenciaram nas temperaturas corporais superficiais das fêmeas suínas. 
No verão e no outono, a área superficial mais quente das fêmeas foi a glândula mamária com $35,9^{\circ} \mathrm{C}$ e $34,9^{\circ} \mathrm{C}(\mathrm{P}<0,01)$. Para a área superficial mais fria, no verão e no outono foi a vaginal, com $30,7^{\circ} \mathrm{C}$ e $30,1^{\circ} \mathrm{C}$, respectivamente $(P>0,05)$. A estação do ano influenciou as temperaturas superficiais do dorso, ventre, pernil, pata, cabeça, glândula mamária, focinho e ocular $(\mathrm{P}<0,01)$, Tabela 13.

Tabela 13- Temperaturas superficiais corporais, em graus Celsius, e seus erros padrões, obtidas a partir da câmera termográfica das fêmeas suínas em fase de maternidade

\begin{tabular}{cccc}
\hline \multirow{2}{*}{ Parâmetros } & \multicolumn{2}{c}{ Estação } & \multirow{2}{*}{$\operatorname{Pr}>|\mathbf{t}|$} \\
\cline { 2 - 3 } & $33,8 \pm 0,35$ & $31,2 \pm 0,36$ & 0,01 \\
\hline Dorso & $35,2 \pm 0,32$ & $33,3 \pm 0,32$ & 0,01 \\
Ventre & $34,9 \pm 0,36$ & $32,7 \pm 0,35$ & 0,01 \\
Pernil & $34,5 \pm 0,34$ & $32,6 \pm 0,33$ & 0,01 \\
Pata & $34,6 \pm 0,34$ & $32,7 \pm 0,36$ & 0,02 \\
Cabeça & $35,9 \pm 0,31$ & $34,9 \pm 0,30$ & 0,03 \\
Glândula Mamária & $34,5 \pm 0,30$ & $32,7 \pm 0,33$ & 0,01 \\
Focinho & $30,7 \pm 1.85$ & $30,1 \pm 1.75$ & 0.59 \\
Vaginal & $35,6 \pm 0,37$ & $33,8 \pm 0,43$ & 0.03 \\
Ocular & & &
\end{tabular}

Fonte: Própria autoria.

Foram encontradas correlações positivas e significativas em relação a cama e as temperaturas superficiais do dorso, ventre, glândula mamária, pernil, cabeça e olhos. Em relação ao piso de concreto foram observadas correlações positivas $(P<0,05)$ em relação às regiões do dorso, ventre, glândula mamária, pernil, pata, focinho, cabeça e olhos (Tabela 11). As temperaturas dorsais, ventrais, do pernil, pata e vaginal apresentaram correlação positiva com a temperatura superficial do telhado $(P<0,05$; Tabela 14).

Tabela 14-Correlações entre temperaturas superficiais corporais de fêmeas mantidas em baias livres de gaiolas e temperatura superficial de estruturas das instalações obtidas com câmera termográfica

\begin{tabular}{cccc}
\hline Temperatura Superficial & Cama & Concreto & Telhado \\
\hline Dorsal & $0,62^{*}$ & $0,69^{*}$ & $0,44^{*}$ \\
Ventral & $0,54^{*}$ & $0,66^{*}$ & $0,39^{*}$ \\
Glândula mamária & $0,63^{*}$ & $0,53^{*}$ & 0,22 \\
Pernil & $0,58^{*}$ & $0,72^{*}$ & $0,41^{*}$ \\
Pata & $0,50^{*}$ & $0,63^{*}$ & $0,44^{*}$ \\
Focinho & 0,48 & $0,52^{*}$ & 0,26 \\
Cabeça & $0,35^{*}$ & $0,57^{*}$ & 0,33 \\
Vaginal & 0,37 & 0,49 & 0,08 \\
Ocular & $0,41^{*}$ & $0,66^{*}$ & 0,45 \\
\hline
\end{tabular}

$\mathrm{P}<0,05^{\star}$. Fonte: Própria autoria. 
A frequência respiratória das fêmeas foi maior à tarde (55 mov. $\left.\mathrm{min}^{-1}\right)$ em relação a manhã (48 mov.min $\left.{ }^{-1}\right)(P>0,05)$. O ambiente controle apresentou 62 mov.min-1 e o ambiente climatizado $41 \mathrm{mov}$. por $\mathrm{min}^{-1}$. O verão apresentou maiores médias (59 mov. $\mathrm{min}^{-1}$ ) em relação ao outono (43 mov. $\left.\mathrm{min}^{-1}\right)(P<0,01)$.

A frequência respiratória apresentou correlação moderada com o dorso $(r=0,312)$ e com o focinho $(r=0,350 ; P<0,05)$. Na relação com as instalações, foram encontradas correlações positivas com o telhado $(r=0,487 ; P<0,05$; Tabela 12) e com a temperatura interna do ambiente $(r=0,353 ; P<0,05)$.

A temperatura retal das fêmeas foi maior à tarde $\left(38,3^{\circ} \mathrm{C}\right)$ em relação ao período da manhã $\left(37,9^{\circ} \mathrm{C}\right)$ e no verão $\left(38,4^{\circ} \mathrm{C}\right)$ comparado ao outono $\left(37,8^{\circ} \mathrm{C}\right)$. O ambiente controle e climatizado apresentaram a mesma temperatura retal de $38,1^{\circ} \mathrm{C}(\mathrm{P}>0,05)$.

O cortisol apresentou maior média no período da tarde $\left(1,94 \mu \mathrm{g} \cdot \mathrm{dL}^{-1}\right)$ em relação ao período da manhã $\left(1,84 \mu \mathrm{g} \cdot \mathrm{dL}^{-1}\right)(\mathrm{P}>0,05)$ e no verão $\left(2,0 \mu \mathrm{g} \cdot \mathrm{dL}^{-1}\right)$ comparado ao outono $(1,78$ $\left.\mu \mathrm{g} \cdot \mathrm{dL}^{-1}\right) \quad(P>0,05)$. Maior média de concentração de cortisol foi encontrada no ambiente controle com 2,25 $\mu$ g.dL $\mathrm{dL}^{-1}$ em relação ao ambiente climatizado com 1,54 $\mu \mathrm{g} \cdot \mathrm{dL}^{-1}(\mathrm{P}>0,05)$.

O cortisol apresentou correlações baixas e negativas com a cama e com o piso de concreto. Com o telhado, foram encontradas correlações positivas em relação ao cortisol $(P>0,05)$, Tabela 15.

Tabela 15-Correlações entre parâmetros fisiológicos de fêmeas suínas e temperaturas superficiais de estruturas das instalações obtidas com câmera termográfica

\begin{tabular}{cccc}
\hline Parâmetros Fisiológicos & Cama & Concreto & Telhado \\
\hline Frequência respiratória & 0,27 & 0,16 & $0,48^{*}$ \\
Cortisol & $-0,03$ & $-0,08$ & 0,17 \\
Temperatura Retal & 0,20 & 0,07 & 0,22 \\
\hline $\mathrm{P}<0,05^{*}$. Fonte: Própria autoria. & & &
\end{tabular}

\subsubsection{Leitões}

As estações do ano e os períodos do dia influenciaram as temperaturas superficiais, enquanto os ambientes climatizado e controle não interferiram nas temperaturas superficiais corporais dos leitões.

$\mathrm{Na}$ estação do verão, a maior temperatura superficial foi encontrada para a área da cabeça $\left(36,7^{\circ} \mathrm{C}\right)$ e no outono se igualaram as temperaturas do dorso, o ventre e a cabeça $\left(35,1^{\circ} \mathrm{C}\right)(\mathrm{P}=0,06)$. A temperatura mais fria encontrada no verão e no outono foi da área do focinho com $34,8^{\circ} \mathrm{C}$ e $33,3^{\circ} \mathrm{C}(\mathrm{P}>0,05$; Tabela 16$)$.

As estações do ano influenciaram as temperaturas superficiais do ventre e pernil $(\mathrm{P}<0,01$; Tabela 16). 
Tabela 16- Temperaturas superficiais corporais obtidas a partir da câmera termográfica de leitões em fase de maternidade mantidos em baias livres de gaiolas

\begin{tabular}{cccc}
\hline \multirow{2}{*}{ Parâmetros } & \multicolumn{2}{c}{ Estação } & \multirow{2}{*}{$\operatorname{Pr}>|\mathbf{t}|$} \\
\cline { 2 - 3 } & Verão $\left(\mathbf{T}^{\circ} \mathbf{C}\right)$ & Outono $\left(\mathbf{T}^{\circ} \mathbf{C}\right)$ & 0,06 \\
Dorso & $36,3 \pm 0,3036$ & $35,1 \pm 0,3270$ & 0,01 \\
Ventre & $36,5 \pm 0,2847$ & $35,1 \pm 0,3112$ & 0,01 \\
Pernil & $36,6 \pm 0,2292$ & $34,9 \pm 0,2631$ & 0,12 \\
Pata & $34,9 \pm 0,3222$ & $33,7 \pm 0,3538$ & 0,06 \\
Cabeça & $36,7 \pm 0,2951$ & $35,1 \pm 0,3219$ & 0,17 \\
Focinho & $34,8 \pm 0,4107$ & $33,3 \pm 0,4584$ & 0,41 \\
Ocular & $36 \pm 0,3909$ & $34,7 \pm 0,4828$ & \\
\hline
\end{tabular}

Fonte: Própria autoria.

As temperaturas superficiais dorsais do pernil, pata, focinho, cabeça e ocular apresentaram correlação positiva com a temperatura superficial da cama. O piso de concreto apresentou correlações positivas para todas as temperaturas superficiais avaliadas enquanto o telhado apenas para o pernil $(\mathrm{P}<0,05$; Tabela 17).

Tabela 17-Correlações entre temperaturas superficiais corporais de leitões mantidos em baias livres de gaiolas e temperatura superficial de estruturas das instalações obtidas com câmera termográfica

\begin{tabular}{cccc}
\hline Temperatura Superficial & Cama & Concreto & Telhado \\
\hline Dorsal & $0,47^{*}$ & $0,50^{*}$ & 0,28 \\
Ventral & $0,30^{*}$ & $0,62^{*}$ & 0,29 \\
Pernil & $0,54^{*}$ & $0,76^{*}$ & $0,43^{*}$ \\
Pata & $0,39^{*}$ & $0,56^{*}$ & 0,25 \\
Focinho & $0,45^{*}$ & $0,56^{*}$ & 0,28 \\
Cabeça & $0,49^{*}$ & $0,66^{*}$ & 0,28 \\
Ocular & $0,52^{*}$ & $0,41^{*}$ & 0,23 \\
\hline
\end{tabular}

$\mathrm{P}<0,05^{\star}$. Fonte: Própria autoria.

O período do dia influenciou a frequência respiratória dos leitões, com maiores médias para o período da tarde (71 mov. $\left.\mathrm{min}^{-1}\right)$ em relação a manhã (58 mov. $\left.\mathrm{min}^{-1}\right)$. A estação do ano com maiores frequências respiratórias foi o verão (69 mov. $\left.\mathrm{min}^{-1}\right)$ comparadas com o outono $\left(60\right.$ mov.min $\left.^{-1}\right)(P<0,01)$. Em ambos os ambientes foi encontrada a mesma frequência respiratória (65 mov. $\left.\mathrm{min}^{-1}\right)(P>0,05)$.

A frequência respiratória e a temperatura retal dos leitões apresentaram correlações baixas e não significativas em relação a cama, concreto e o telhado.

\subsection{Discussão}

A suinocultura é considerada como uma das formas mais intensivas de criação animal, caracterizada pelo espaço restrito, pouca movimentação e interação entre os animais, 
ocasionando alterações importantes no comportamento e conforto dos suínos (PUTTEN, 1989). No entanto, avanços na genética, nutrição, manuseio dos animais em conjunto com a pressão imposta aos produtores pelos consumidores por uma criação com melhor bem-estar promoveram a adoção de práticas de criação éticas melhorando o bem-estar e a capacidade da produção animal (HARVEY; HUBBARD, 2013).

A criação de suínos em gaiolas causa frustração, ao impedir o comportamento social, uma vez que suínos são animais gregários, com uma hierarquia definida (DUCAN, 1997). A retirada das gaiolas de fêmeas em fase de lactação permite a expressão de parte de seus comportamentos inatos, como exploração da cama, de se exercitar, interações com sua leitegada e comportamentos lúdicos. A criação sem a presença de celas permite as fêmeas permanecerem em posições como decúbito lateral e ventral, com maior conforto, além de maiores interações com leitões durante a amamentação. Além disso, há melhor controle da alimentação individual dos animais, com diversos sistemas de alimentação disponíveis (BENCH et al., 2013).

A impossibilidade de exercer comportamentos inatos a espécie aumenta o nível de cortisol de fêmeas alojadas em gaiolas (BROOM; FRASER, 2010). Neste estudo, no ambiente controle foram encontrados maiores níveis de cortisol, relacionados ao tipo do manejo empregado, que gera ruídos e tem um número alto de pessoas envolvidas além da maior temperatura ambiental nesta instalação na estação do verão. As concentrações de cortisol das fêmeas foram maiores no período da tarde e uma provável explicação pode estar relacionada as concentrações de hormônios glicocorticóides serem mais elevadas no período diurno e reduzidas durante a noite em suínos (HILLMANN et al., 2008; JANSSENS et al., 1995). No entanto, mesmo com diferenças em seus valores numéricos, os resultados encontrados não apresentam diferenças fisiológicas significativas.

As variações na concentração de cortisol decorrem devido as reações aos agentes estressores e aos desafios ambientais (DALLA COSTA et al., 2006; KOEPPEN; STANTON, 2009). No entanto, pequenas variações no níveis de cortisol, como as encontradas neste estudo, apresentam importantes particularidades em conjunto com os achados significativos na temperatura ocular das fêmeas, demonstrando que quando há ativação do eixo hipotálamo-hipófise-adrenal os níveis de cortisol aumentam com alterações do fluxo sanguíneo, o que causa as variações na produção de calor, que pode ser analisado por meio da termografia ocular (CHURCH et al., 2009).

A frequência respiratória foi maior a tarde, no verão e no ambiente controle para fêmeas e leitões. No entanto, para as fêmeas a temperatura retal foi a mesma para ambos os ambientes. Isso pode indicar que o mecanismo de perda de calor por evaporação está sendo suficiente para a termólise, mesmo não sendo um mecanismo ótimo para o animal, devido as intercorrências do seu excesso. Animais diurnos comumente possuem uma variação retal 
mínima no período da manhã e máxima no período da tarde, fazendo com que a temperatura do ar a tarde seja a responsável pela elevada temperatura retal de suínos nos trópicos (MEDEIROS et al., 2007). A temperatura retal é tida como um parâmetro adequado para se estimar o efeito da temperatura ambiente sobre os animais (ORLANDO, 2001).

A temperatura retal das fêmeas e dos leitões apresentou-se maior a tarde, na estação do verão, seguindo uma coerência visto que estas condições exibiram maior temperaturas ambientais em decorrência do horário e da estação. Neste estudo, os leitões, tinham acesso exclusivo a escamoteadores para proteção contra o frio, o que pode ter influenciado ao aquecimento e a apresentação de temperaturas retais próximas em ambos os tratamentos. Segundo Silva et al. (2008) parâmetros fisiológicos como a temperatura retal, frequência respiratória, temperatura superficial da pele sofrem influência direta do período do dia, já que a tarde a temperatura do ar é frequentemente maior neste período em relação aos horários da manhã, originando aumento dessas variáveis fisiológicas importantes para análise de estresse por calor.

A temperatura ocular de fêmeas e leitões mensuradas por meio de pontos foram maiores no verão. Segundo Schmidt et al. (2013) a temperatura ocular está relacionada à temperatura do núcleo corporal devido a sua imediação ao cérebro. Os valores de temperatura infravermelha ocular podem ser um significativo indicador de temperatura corporal, além de um método adequado para estimar a condição fisiológica de estresse em suínos confinados (WESCHENFELDER et al., 2013), além de torna-se um prático e importante substituto para metodologias invasivas de mensuração (BROWN-BRANDL et al., 2013; JOHNSON et al., 2011; PULIDO-RODRÍGUEZ et al., 2017). Segundo Weschenfelder et al. (2013) a temperatura infravermelha ocular é um indicador importante de temperatura corporal e um método útil para avaliar a condição fisiológica de estresse em suínos, constituindo-se um substituto para métodos invasivos de análise (BROWN-BRANDL et al., 2013; JOHNSON et al., 2011).

A temperatura da cabeça e do focinho das fêmeas e leitões apresentaram-se como um importante mecanismo de mensuração de calor. Segundo Schmidt et al. (2013) os olhos e atrás das orelhas (na cabeça) são pontos confiáveis para aferição de temperatura de superfície corporal por meio da técnica de termografia. Ainda, em situações de estresse por calor a transferência circulatória para a pele é expandida por meio da dilatação das arteríolas dos leitos vasculares cutâneos e por meio da abertura das anastomoses arteriovenosas nos membros, orelhas e focinho permitindo aumentar o fluxo sanguíneo periférico ocasionando perda de calor para o ambiente a partir da pele superficial (CUNNINGHAN, 2008). Avaliando parâmetros fisiológicos de suínos em conforto $\left(22^{\circ} \mathrm{C}\right)$ e de estresse térmico $\left(32^{\circ} \mathrm{C}\right)$, Manno et al. (2006) aferiram do reto, da nuca, da paleta e do pernil, encontrando valores das 
temperaturas superficiais $9,5 \%$ superiores em animais em estresse por calor comparados aos suínos submetidos ao conforto térmico.

A temperatura dorsal das fêmeas e leitões foram maiores na estação do verão e no período da tarde com maiores médias encontradas no ambiente controle em relação ao climatizado. Diante da exposição a temperaturas mais altas no ambiente controle, estas foram responsáveis pelo aumento da temperatura dorsal quando comparados ao ambiente climatizado, principalmente devido a presença de água e ventilação que permitem maior troca de calor. Segundo Silva (2009) as temperaturas superficiais mais altas devem-se ao aumento na circulação sanguínea periférica utilizada como forma de dissipar o calor corporal. Os leitões ainda, permaneceram em ócio, frequentemente amontoados e dentro do escamoteador, o que também pode aumentar a temperatura dorsal destes animais. A temperatura superficial do dorso é considerada boa medida para descrever o ambiente no qual o animal está alojado (COLLIER et al., 2006; STEWART et al., 2008; WESCHENFELDER et al., 2013).

As estações do ano influenciaram as temperaturas do ventre de fêmeas e leitões com maiores temperaturas no verão, possivelmente devido as maiores temperaturas dentro das instalações. Para as fêmeas, houve alta correlação com a cama, piso de concreto e telhado, podendo estar relacionado as temperaturas menores das estruturas no ambiente climatizado e as áreas úmidas, com dejetos e a capacidade de utilizar os bebedouros para se refrescar das fêmeas no ambiente controle. Em relação aos leitões, apenas o piso de concreto apresentou correlações positivas e significativas indicando que o piso de concreto pode auxiliar na redução do calor, por condução, com mais benefícios com o decorrer do crescimento dos animais ao longo da fase de maternidade.

A temperatura da glândula mamária das fêmeas foi a maior das médias de temperatura encontradas comparando as estações do ano, podendo este resultado estar relacionado as maiores temperaturas encontradas na estação mais quente. Corroborando com este resultado, Kotrbácek e Nau (1985) indicoram em seu estudo que porcas após o parto possuem como áreas superficiais mais quentes na glândula mamária, onde nos últimos dias de gestação de porcas, particularmente após o parto, a temperatura da pele sobre a glândula mamária representava a área mais quente da superfície corporal, com temperaturas de $39^{\circ} \mathrm{C}$ no primeiro dia de lactação e em outros períodos a temperatura permaneceu entre 37 e $38^{\circ} \mathrm{C}$.

As temperaturas dos ambientes foram menores para o ambiente climatizado, com maiores temperaturas no ambiente controle devido a climatização utilizada. As variações de temperatura dos ambientes estão relacionadas ao tipo da instalação, com pé direito baixo, em localização norte e sul, a alocação dos tratamento na instalação, onde na área controle, o vento proveniente do ambiente melhor se propagava nesta área em relação a climatizada, por estar no meio da instalações e as temperaturas baixas no outono com precipitações de chuva consideradas moderadas e intensas nessa estação. 
Em relação as instalações, o telhado apresenta-se em altura não recomendada para uma ventilação adequada a criação de suínos, mesmo construídos por telhas de barro Segundo Furtado et al. (2003) as telhas de barro oferecem melhor conforto quando comparadas a telha de cimento amianto, por exemplo. O telhado, neste estudo, apresentou efeito de horários, estação do ano e ambientes, demonstrando a importância da cobertura para o conforto térmico de matrizes e leitões. Em instalações de confinamento de animais, o telhado tem função primária na determinação de trocas térmicas, especialmente, em regiões tropicais (TURNPENNY et al., 2000). Com isso, o fluxo de calor através das coberturas é o motivo principal do desconforto no interior das instalações rurais (ROSA, 1984). Segundo Abreu et al. (2001), uma vez que a energia térmica da superfície superior da telha é transmitida para a superfície inferior da telha elevando a temperatura interna da instalação, principalmente nas horas de maior estresse por calor, demonstrando a importância dos enriquecimentos no interior deste tipo de instalação.

No interior das instalações de confinamento, aproximadamente $20 \%$ da carga térmica de radiação incidente decorre do telhado e esse efeito pode ser alterado pela escolha do material utilizado além de se aumentar a distância entre o piso e a cobertura utilizada (SABINO et al., 2011). Dessa forma, em regiões tropicas, têm-se usado mecanismos para diminuir o ganho de calor total das telhas, contribuindo para gerar efeito refrescante para as instalações de criação animal (FAGHIH; BAHADORI, 2010).

A cama de bagaço de cana e o piso de concreto apresentaram influência sobre as temperaturas superficiais dos leitões e porcas principalmente devido as trocas por condução, importantes á espécie suína devido sua dificuldade em perder calor por sudação. Notou-se que as fêmeas preferiram permanecer em áreas sem a presença de camas em horários com temperaturas mais elevadas se direcionando a áreas com piso de concreto com a presença de irrigadores de água no telhado do ambiente climatizado ou na área úmida do controle. Apesar de se constituir como excelente enriquecimento ambiental e de forragem para pisos, evitando ferimentos aos suínos, a cama aumenta a temperatura dentro das instalações. Segundo Warriss (1996), é recomendado que se evite a utilização de cama de palha quando a temperatura for maior que $20^{\circ} \mathrm{C}$ para evitar o estresse por calor, substituindo por areia molhada ou maravalha a fim de manter os animais em conforto térmico.

A utilização de ventiladores e aspersores de água no telhado aumentam o conforto térmico e comportamental de suínos, por permitir além de menores temperaturas ambientais, que fêmeas possam apresentar comportamentos naturais e importantes dos suínos, como explorar e ludicidades, com ênfase a perda de calor por condução, podendo ser identificado o estresse causado pelo calor por meio da utilização da termografia de infravermelho. 


\subsection{Conclusão}

Apesar da climatização ter diminuído a temperatura do ambiente não foi suficiente para reduzir a temperatura superficial corporal de fêmeas e leitões abaixo da sua temperatura de conforto quando os animais são inseridos em baias livres de gaiolas em fase de maternidade. Contudo, a utilização de termografia infravermelha permitiu identificar as áreas superficiais mais quentes e frias dos suínos em diferentes ambientes auxiliando no aperfeiçoamento das instalações buscando melhorar o bem-estar de animais alojados em confinamento. 


\section{Referências}

ABREU, P. G.; ABREU, V. M. N.; DALLA COSTA, O. A. Avaliação de coberturas de cabanas de maternidade em sistema intensivo de suínos criados ao ar livre (Siscal), no verão.

Revista Brasileira de Zootecnia, Viçosa, v. 30, p. 1728-1734, 2001.

BENCH, C. J. et al. Group gestation sow housing with individual feeding - II: How space allowance group size and composition, and flooring affect sow welfare. Livestock Science, Amsterdam, v. 152, p. 218-227, 2013.

BRACKE, M. B. M. et al. Formalized review of environmental enrichment for pigs in relation to political 12 decision making. Applied Animal Behaviour Science, Amsterdam, v. 98, p. 165-182, 2006.

BROOM, D. M.; FRASER, A. F. Comportamento e bem-estar de animais domésticos. Barueri: Manole, 2010.

BROWN-BRAND, T.; EIGENBER, R.; PURSWELL, J. Using thermal imaging as a method of investigating thermal thresholds in finishing pigs. Biosystems Engineering, London, v. 114, p. 327-333, 2013.

CALDARA, F. R. et al. Piglets' surface temperature change at different weights at birth. Asian-Australasian Journal of Animal Sciences, Champaign, v. 27, p. 431-438, 2014.

COLLIER, R. J.; DAHL, G. E.; VANBAALE, M. J. Major advances associated with environmental effects on dairy cattle. Journal of Dairy Science, New York, v. 89, p. 12441253, 2006.

CUNNINGHAM, J. G.; KLEIN, B. G. B. Glândulas endódrinas e suas funções. In: Tratado de fisiologia veterinária. 4. ed. Rio de Janeiro: Elsevier, 2008. cap. 34, p. 431466.

CHURCH J. S.; COOK, N. J.; SCHAEFER, A. L. Recent applications of infrared thermography for animal welfare and veterinary research: everything from chicks to elephants. In: CONFERENCE INFRAMATION, 2009, Las Vegas. Disponível em: $<$ https://www.researchgate.net/publication/272209934_Recent_Applications_of_Infrared_The rmography_for_Animal_Welfare_and_Veterinary_Research_Everything_from_Chicks_to_Ele phants>. Acesso em: 5 set. 2018.

DALLA COSTA, O. A. et al. Efeito do tempo de jejum dos suínos na granja sobre o bemestar, medido pelo cortisol na saliva e pela frequência cardíaca, durante o manejo préabate. Concórdia: Embrapa Suínos e Aves, 2006. 3 p. (Comunicado técnico, 439).

DUNCAN, I. J. H.; FRASER, D. Understanding animal welfare. In: APPLEBY, M. C.; HUGHES, B. O. (Ed.). Animal welfare. Wallingford, UL: CAB International, 1997. p. 19-31. 1997.

EDDY, A. L.; HOOGMED, V. L. M.; SNYDER, J. R. The role of termography in the management of equine lameness. The Veterinary Journal, London, v. 162, p.172-181, 2001.

ESCRIBANO, D.; FUENTES-RUBIANO, M.; CERÓN, J. J. Validation of an automated chemiluminescent immunoassay for salivary cortisol measurements in pigs. Journal of Veterinary Diagnostic Investigation, Thousand Oaks, v. 24, p. 918-923, 2012. 
FAGHIH, A. K.; BAHADORI, M. N. Three dimensional numerical investigation of air flow over domed roofs. Journal of Wind Engineering and Industrial Aerodynamics, Amsterdam, v. 98, p. 161-168, 2010.

FURTADO, D. A.; NASCIMENTO, J. W. B.; AZEVEDO, P. V. Análise do conforto ambiental em galpões avícolas utilizando telhas de barro e suas associações no agreste paraibano.

Revista Brasileira de Ciência Avícola, Campinas, n. 5, p. 107, 2003.

HARVEY, D.; HUBBARD, C. Reconsidering the political economy of farm animal welfare: An anatomy of market failure. Food Policy, Kidlington, v. 38, p. 105-114.7, 2013.

HILLMANN, E. et al. Effects of weight, temperature and behaviour on the circadian rhythm of salivary cortisol in growing pigs. Animal, Cambridge, v. 2, n. 3, p. 405-409, 2008.

HOOGMOED, L. M.; SNYDER, J. R. Use of infrared thermography to detect injections and palmar digital neurectomy in horses. The Veterinary Journal, London, v. 164, p.129-141, 2002.

JANSSENS, C. J.; HELMOND, F. A.; WIEGANT, V. M. The effect of chronic stress on plasma cortisol concentrations in cyclic female pigs depends on the time of day. Domestic Animal Endocrinology, Philadelphia, v. 12, p. 167-177, 1995.

JOHNSON, S. R. et al. Thermographic eye temperature as an index to body temperature in ponies. The Journal of Equine Veterinary Science, Maryland Heights, v. 31, p. 63-66, 2011.

KOEPPEN, B. M.; STANTON, B. A. (Ed.). Berne \& Levy fisiologia. Rio de Janeiro: Elsevier, 2009.

KOPPEN. Clima dos Municípios Paulistas. 2018. Informações sobre o Clima- Campinas, São Paulo. Disponível em: <http://www.cpa.unicamp.br/outras-informacoes/clima-dosmunicipios-paulistas.html>. Acesso em: 20 ago. 2018.

KOTRBACEK, V.; NAU, H. R. The Changes in skin temperatures of periparturient sows. Acta Veterinaria Brno, Brno, v. 54, p. 35-40, 1985.

MANNO, M. C. et al. Efeitos da temperatura ambiente sobre o desempenho de suínos dos 30 aos 60kg. Revista Brasileira de Zootecnia, Viçosa, v. 35, p. 471-477, 2006.

MEDEIROS, L. F. D.; VIERIRA, D. H.; OLIVEIRA, C. A. Avaliação de parâmetros fisiológicos de caprinos SPRD (sem padrão racial definido) pretos e brancos de diferentes idades, à sombra, no município do Rio de Janeiro, RJ. Boletim Indústria Animal, Nova Odessa, v. 64, p. 277-287, 2007.

MOLENTO, C. F. M. Bem-estar e produção animal: aspectos econômicos revisão. Archives of Veterinary Science, Curitiba, v.10, p.1-11, 2005.

ORLANDO, U. A. D. Nível de proteína bruta da ração e efeito da temperatura ambiente sobre o desempenho e parâmetros fisiológicos de leitoas em crescimento. 2001. $77 \mathrm{f}$. Dissertação (Mestrado) - Universidade Federal de Viçosa, Viçosa, 2001.

PULIDO-RODRIGUÉZ, L. F. et al. Termografia infravermelha da superfície ocular como indicador de estresse em suínos na fase de creche. Pesquisa Veterinária Brasileira, Seropedica, v. 37, p. 453-458, 2017. 
PUTEN, G. V. The pig: Model for discussing animal behavior and welfare. Applied Animal Behaviour Science, Amsterdam, v. 22, p. 115-28, 1989.

PHILLIPS, P. K.; HEATH, J. E. An infrared thermographic study of surface temperature in the euthermic woodchucks (Marmota monax). Comparative Biochemistry and Pyshiology. Part A, Molecular \& Integrative Physiology, New York, v. 129, p. 557-562, 2001. RODRIGUES, N. E. B.; ZANGERONIMO, M. G.; FIALHO, E. T. Adaptações fisiológicas de suínos sob estresse térmico. Revista Eletrônica Nutritime, Viçosa, v. 7, p. 1197-1211, 2010.

ROSA, Y. B. C. J. Influência de três materiais de cobertura no índice de conforto térmico em condições de verão, para Viçosa. 1984. 77 f. Dissertação (Mestrado) Universidade Federal de Viçosa, Viçosa, 1984.

SABINO, L. A. et al. Comportamento suíno influenciado por dois modelos de maternidade. Revista Brasileira de Engenharia Agrícola e Ambiental, Campina Grande, v. 15, p. 13211327, 2011.

SILANIKOVE, N. Effects of heat stress on the welfare of extensively managed domestic ruminants. Livestock Production Science, Amsterdam, v. 67, p. 1-18, 2000.

SCHAEFER, A. L.; MATTHEWS, L. R.; COOK, N. J. Novel non-invasive measures of animal welfare. In: JOINT NAWAC/ISAE CONFERENCE, Hamilton, New Zealand, 2002. Animal Welfare and Behaviour, Hamilton, New Zealand, 2002. p. 421-467. (Science solution).

SILANIKOVE, N. Effects of heat stress on the welfare of extensively managed domestic ruminants. Livestock Production Science, Amsterdam, v. 67, p.1-18, 2000.

SILVA, I. J. O. et al. Influência do sistema de alojamento no comportamento e bem-estar de matrizes suínas em gestação. Revista Brasileira de Zootecnia, Viçosa, v. 37, p. 13191329, 2008.

SCHMIDT, M. et al. Application of infrared thermography on lactating sows. Landtechnik, Graz-Neuhart, v. 68, n. 4, p. 228-231, 2013.

STARLING, J. M. C. et al. Variação estacional dos hormônios tireoideanos e do cortisol em ovinos em ambiente tropical. Revista Brasileira de Zootecnia, Viçosa, v. 34, p. 2064-2069, 2005.

STEWART, M. et al. Eye temperature and heart rate variability of calves disbudded with or without local anaesthetic. Physiology \& Behavior, Oxford, v. 93, p. 789-797, 2008.

TAROU, L. R.; BASHAW, M. J. Maximizing the effectiveness of environmental enrichment: Suggestions from the experimental analysis of behaviour. Applied Animal Behaviour Science, Amsterdam, v. 102, p. 189-204, 2007.

TURNPENNY, J. R. et al. Thermal balance of livestock. 2. Applications of a parsimonious model. Agricultural and Forest Meteorology, Amsterdam, v. 101, p. 29-52, 2000.

VAN DE WEERD, $\mathrm{H}$. A. et al. A systematic approach towards developing environmental enrichment for 15 pigs. Applied Animal Behaviour Science, Amsterdam, v. 84, p. 101-118, 2003. 
VERCELLINO, R. A. et al. Uso da termografia infravermelha para análise de trocas de calor de eqüinos em condições de treinamento. In: REUNIÃO ANUAL DA SOCIEDADE BRASILEIRA DE ZOOTECNIA, 2010, Salvador. Anais... Salvador, 2010. 1 CD-ROM.

WESCHENFELDER, A. V. et al. Use of infrared ocular thermography to assess physiological conditions of pigs prior to slaughter and predict pork quality variation. Meat Science, Amsterdam, v. 95, 616-620, 2013. 
Os apêndices A e B são estudos realizados durante o período experimental, porém sem a utilização de climatização e por isso foram anexados separadamente.

\section{APÊNDICE A - METODOLOGIA COMPORTAMENTAL E DE VOCALIZAÇÃO PARA AVALIAÇÃo de ESTRESSE dE LEITÕES E PORCAS ANTES E DEPOIS DE MANIPULAÇÕES ROTINEIRAS ${ }^{2}$}

\section{Resumo}

Avaliar o comportamento animal auxilia na percepção de alterações no bem-estar. Objetivouse identificar a ocorrência de alterações comportamentais e as suas consequências sobre o bem-estar de porcas e leitões, comparando seus comportamentos antes e depois da realização de práticas de rotina na suinocultura.. Utilizou-se 26 fêmeas da linhagem Large White $x$ Landrace, com total de trezentos e quinze leitões avaliados. Etogramas específicos para as idades foram confeccionados para avaliações no segundo dia de vida dos leitões, com intervalo de cinco minutos, uma hora antes e depois dos procedimentos, totalizando duas horas. A frequência respiratória, outro parâmetro de bem-estar, foi obtida por observação visual direta das porcas, durante um minuto, nos primeiros e últimos cinco minutos das observações de comportamento, antes e depois das práticas. O comportamento foi expresso em percentual, de animais na atividade, no momento avaliado. Os dados foram analisados estatisticamente pelo procedimento Glimmix do SAS, com comparação de médias pelo teste$t$. Através deste obteve-se uma diferença significativa nos comportamentos de explorar, ficar em ócio e mamar, realizados pelos leitões. Em relação às matrizes, observou-se diferenças significativas para os comportamentos estereotipados e ócio. O comportamento das matrizes, juntamente com sua leitegada, mostrou efeito significativo para estereotipias, ócio, Alimentação e beber, após a reinserção dos leitões. A realização destas análises é uma importante ferramenta para identificar alterações comportamentais e de bem-estar que práticas como mossagem, castração e desgaste de dentes ocasionam aos leitões.

\section{Introdução}

Nos primeiros dias após nascimento, os leitões são submetidos a práticas ainda rotineiras na suinocultura como desgaste ou corte dos dentes, castração sem anestesia, mossagem australiana e caudectomia. Esses métodos geram dor aguda e crônica, estresse e consequente queda no desempenho dos suínos (BATES et al., 2003).

Para a realização das práticas, os lactentes são encaminhados para salas de manejo, locais onde os leitões permanecem separados das porcas. Apartados da mãe, apresentam

\footnotetext{
2 Submetido ao International Journal of Biometeorology
} 
comportamentos alterados, representados pelo aumento da movimentação e da vocalização, frequentemente notórios após as primeiras horas da separação, que, normalmente, se reduzem ao longo dos dias após o retorno junto a fêmea (WEARY; FRASER, 1997).

O local de realização dos procedimentos com leitões necessita ser afastado o bastante das baias das fêmeas para garantir que as matrizes não ouçam os ruídos emitidos pelos lactentes, caso contrário, haverá maior estresse ocasionando consequências negativas na produção de leite, no relacionamento entre porca e leitões, apresentação de comportamento agressivo ou estereotipado e consequentes perdas para o bem-estar.

Diante do estresse gerado pela separação e pelos procedimentos realizados nos leitões torna-se importante avaliar o nível de estresse por métodos simples e que não sejam invasivos aos suínos. O nível de cortisol pode ser medido a partir de colheitas de sangue e saliva, no entanto a colheita de sangue é uma atividade que gera estresse, podendo afetar o bem-estar e o desempenho animal (DALLA COSTA et al., 2006) e a colheita de saliva em lactentes nos primeiros dias de lactação é complexa, uma vez que nesta idade, leitões apresentam pouco interesse em mastigar objetos, atentando-se mais a amamentação e a permanecer em ócio. Outro obstáculo importante à realização de estudos que envolvam dosagens hormonais é o custo da análise por amostra sobretudo quando se refere ao uso de kits laboratoriais (PEREIRA, 2007).

Buscando metodologias que facilitem a avaliação do estresse em suínos recémnascidos, atualmente tem se procurado métodos de análise não invasivos para estimativa da bem-estar e do tratamento destinado aos animais confinados. Para isso, o estudo do comportamento tem sido considerado um método prático, rápido e não doloroso (DUPJAN et al., 2008; POLETTO, 2010), devido a facilidade em se obter dados sem contenção e agressão física e psicológica dos animais.

O estudo da ciência cognitiva tem importância singular como metodologia para avaliação das emoções e melhoria do bem-estar animal (MENDEL; PAUL, 2004), uma vez que a capacidade de sentir é primordial para manter a bem-estar dos animais (DUCAN, 1993). Comportamentos anormais, como as estereotipias, canibalismo, automutilação, agressividade e apatia indicam condições pobres de bem-estar (BROOM; MOLENTO 2004; ZANELLA, 1995), assim como alterações fisiológicas como a frequência cardíaca, respiratória, respostas hormonais e do sistema imunológico (BROOM; MOLENTO, 2004).

A análise da vocalização direcionada ao estudo do comportamento dos suínos auxilia no conhecimento sobre o estresse, desconforto e dor a que os animais possam estar expostos (PUPPE et al., 2005) devido a situações estressantes como contenção para manejo, separações e fome a partir de vocalizações de alta frequência (FRASER, 1975), sendo, ainda, um método utilizado para expressão de sentimentos e empregada como parâmetro para lactentes em suas primeiras semanas após o nascimento (HESSING et al., 1993). 
Diante dos métodos que mensuram o estresse de suínos e as suas barreiras, este estudo foi desenvolvido com o objetivo de se avaliar alterações comportamentais, suas consequências sobre o bem-estar de porcas e leitões após práticas dolorosas de manejo e a capacidade do estudo do comportamento em reconhecer o estresse em suínos na fase de maternidade como método de análise não invasiva.

\section{$2 \quad$ Material e Métodos}

O experimento foi realizado nas instalações de maternidade do Setor de Suinocultura da Universidade de São Paulo, Campus Fernando Costa, em Pirassununga, estado de São Paulo, durante os meses de março a junho de 2016. O presente estudo foi aprovado pela Comissão de Ética no Uso de Animais CEUA № 3758260116 da Faculdade de Zootecnia e Engenharia de Alimentos da Universidade de São Paulo.

Foram avaliadas 26 fêmeas, F1, Landrace x Large White, e suas respectivas leitegadas, totalizando 315 leitões, em sistema de confinamento em celas parideiras. $O$ manejo nutricional era realizado de manhã e à tarde para fêmeas e leitões, com $7 \mathrm{~kg}$ ao dia para fêmeas e progressivo para os leitões, iniciando com 200 gramas na primeira semana e $500 \mathrm{~g}$ na semana do desmame.

Os dados foram colhidos no segundo dia de nascido dos lactentes, no momento da realização das práticas de aplicação intramuscular de ferro dextrano, mossagem australiana, castração dos machos e desgaste dos dentes dos lactentes, de ambos os sexos. Para a realização das práticas dois manejadores, funcionários da granja, realizavam o trabalho entre 7 e 9 horas da manhã, buscando os períodos de horário onde a temperatura era mais amena. O tempo de realização de cada prática foi mensurado individualmente a partir de cronômetros digitais, utilizado do momento em que o procedimento tinha início até a finalização deste.

\subsection{Análise etológica de leitões e porcas}

Para obtenção de dados comportamentais, foi construído um etograma (DEL-CLARO, 2004) para amostragem da frequência de realização dos comportamentos dos leitões e da porca, separadamente. Entre os comportamentos avaliados estão: ócio, mamar, alimentar, beber, estereotipia, agonistico, ludicidade, exploratório, eliminação (Tabela 1).

A observação dos leitões e matrizes suínas se deu na forma dirigida (FERREIRA et al., 2005) por amostragem de escaneamento. As observações intervalares dos leitões foram obtidas a cada cinco minutos, durante uma hora antes e uma hora depois da realização dos procedimentos com leitões, totalizando duas horas, por leitegada. As fêmeas foram avaliadas uma hora antes, durante a realização das práticas e uma hora depois da volta da leitegada as 
baias. Dois observadores foram treinados para identificar os principais pontos comportamentais dos animais.

A frequência respiratória foi obtida por observação visual direta e a contagem dos movimentos do flanco das porcas por 1 minuto, nos primeiros e últimos cinco minutos das observações de comportamento, antes e depois dos procedimentos. Os leitões foram avaliados 5 minutos antes da saída e após 15 minutos do retorno as baias, junto as porcas.

Tabela 1 - Etograma de trabalho dos comportamentos observados durante a realização do estudo

\begin{tabular}{|c|c|}
\hline Comportamentos & Descrição \\
\hline Lúdico & $\begin{array}{l}\text { Suíno correndo dentro da baia com ou sem finalização } \\
\text { diversificada que acaba em rodopio ou parada, } \\
\text { jogando-se no chão ou sobre outro leitão. }\end{array}$ \\
\hline Estereotipado & $\begin{array}{c}\text { Comportamento compensatório apresentado através de } \\
\text { atividades repetitivas ou viciosas, sem funções } \\
\text { adaptativas, como mastigação falsa, engolir o ar, } \\
\text { chupar ou enrolar a língua, morder as barras ou parte } \\
\text { das instalações. }\end{array}$ \\
\hline Agonístico & $\begin{array}{c}\text { Ato em que dois ou mais animais se agridem por meio } \\
\text { de perseguição, empurrões, mordidas, cabeçadas entre } \\
\text { outros. }\end{array}$ \\
\hline Exploratório & $\begin{array}{l}\text { Revolver a cama, cheirar os objetos, explorando o } \\
\text { chão, parede, barra ou outras partes da baia com o } \\
\text { focinho, boca ou língua. }\end{array}$ \\
\hline Beber & $\begin{array}{l}\text { Ato em que o animal realiza o acionamento do } \\
\text { bebedouro tipo chupeta consumindo água. }\end{array}$ \\
\hline Alimentação & Ingestão de ração do comedouro. \\
\hline Ócio & $\begin{array}{l}\text { Suíno parado, sem se deslocar, sem atividade } \\
\text { aparente. }\end{array}$ \\
\hline Mamar & $\begin{array}{l}\text { Leitão apoia o focinho perto do teto da porca, ficando } \\
\text { em contato com ele ou realizando movimento de } \\
\text { sucção por mais de } 5 \text { segundos. }\end{array}$ \\
\hline Defecação & Ato de defecar. \\
\hline Micção & Ato de urinar. \\
\hline
\end{tabular}

Fonte: Própria autoria

Foi realizada uma segunda análise comportamental dos leitões no momento em que os animais estavam contidos para a realização das práticas, onde foram analisados comportamentos de agressão, esquiva, positivo, inatividade e outros, Tabela 2.

As medidas de comportamento foram analisadas através de análise de variância, utilizando o procedimento Mixed para os leitões com efeitos de tratamento, hora e local e Glimmix para as fêmeas com efeitos de tratamento, hora e local por meio do programa SAS (2017) e as médias foram comparadas utilizando o teste de PDIFF a 5\%. 
Tabela 2 - Comportamentos avaliados durante a contenção dos leitões para realização das práticas de desgaste dos dentes (1), marcação australiana (2) e castração (3)

\begin{tabular}{|c|c|}
\hline Comportamento & Descrição \\
\hline Agressão & Tentativa de morder ou cabecear o manejador. \\
\hline Esquiva & $\begin{array}{l}\text { Tentativa de sair e ou fugir da contenção do } \\
\text { manejador. }\end{array}$ \\
\hline Positivo & $\begin{array}{l}\text { Tentativa de carícia ou ludicidade com o } \\
\text { manejador. }\end{array}$ \\
\hline Inatividade & $\begin{array}{l}\text { Ato de permanecer inativo, sem qualquer } \\
\text { movimentação. }\end{array}$ \\
\hline Outros & $\begin{array}{l}\text { Qualquer outro comportamento que não esteja } \\
\text { indicado na descrição anterior. }\end{array}$ \\
\hline
\end{tabular}

Fonte: Própria autoria

\subsection{Análise de vocalização e comportamento durante procedimentos rotineiros}

Após a retirada das leitegadas das gaiolas de parição, no segundo dia de nascimento dos leitões, os animais foram encaminhados a sala de manejo, alojados em caixas plásticas, onde foram realizadas práticas de desgaste dos dentes (1), mossagem australiana (2) e castração (machos) (3) por dois manejadores treinados da própria granja.

A sala de manejo não possuía aparelhos ou objetos que interferissem no ruído. A intensidade do ruído emitido pelo desgastador foi considerada na análise, incluída como fonte de estresse para o animal, devido à proximidade com seu aparelho auditivo.

Durante os procedimentos, foram mensuradas as intensidades mínimas e máximas do grito dos leitões com auxílio de um decibelimetro marca MSL- 1352 C - Minipa, com data logger (Memória) de até 32000 registros, microfone de eletreto de 1/2", faixa dinâmica de $100 \mathrm{~dB}$, com interface RS-232 e software, com registro de máximo e mínimo, resposta rápida (FAST) e lenta (SLOW), precisão de $+/-1.5 \mathrm{~dB}(94 \mathrm{~dB} / 1 \mathrm{kHz})$, ponderação A e C em frequência e faixa de medida de $30 \mathrm{~dB}$ a $130 \mathrm{~dB}$, a uma distância máxima de dez centímetros da cavidade bucal dos leitões, que eram mantidos contidos pelo manejador. Assim, a duração da vocalização foi considerada como o tempo em que os manejadores utilizaram para iniciar e terminar a execução da prática de manejo.

Para a análise dos dados foram utilizados efeitos fixo da velocidade de Realização das práticas e o efeito entre tempo de realização dos leitões e intensidade do grito emitido pelos lactentes pelo SAS (2017). A comparação de médias foi realizada pelo teste-T e PDIFF. 
A média de tempo para realização das práticas foi maior para a castração, seguida pelo desgaste dos dentes e pela mossa australiana, com médias de 24,21, 16,03 e 15,05 segundos, respectivamente $(P<0,01)$.

Leitões ao retornarem das práticas rotineiras tendem a apresentar maior vocalização e frequência de comportamentos exploratório (5,2 e 8,2\%) e ócio $(68,9$ e 70,5\%) ( $P>0,01)$, e menor procura pelos tetos $(24,6 ; 18,8 \%)$ em relação ao período anterior ao manejo $(P>0,01)$, enquanto que com menores regularidades $(P>0,05)$ foram observados os comportamentos de beber, defecação e urina, estereotipado, lúdico e agonístico.

Neste estudo, em relação aos comportamentos realizados pelas porcas, antes dos leitões serem retirados para o manejo rotineiro, foram encontrados efeitos significativos para os comportamentos estereotipados, ócio, enquanto que para os comportamentos realizados depois do retorno dos lactentes, efeitos significativos foram encontrados para alimentação e beber $(P>0,01)$, com maiores médias pela procura pelo comedouro e bebedouro de agua pelas fêmeas para a volta dos lactentes a baia.

Maiores médias de frequências respiratórias das fêmeas foram encontradas para a volta dos leitões às baias, com 24,9 movimentos respiratórios por minuto (mov. $\mathrm{min}^{-1}$ ) para antes da saída e 32,5 mov. $\mathrm{min}^{-1}$ para o retorno $(P>0,01)$. Para os leitões, antes da saída para os procedimentos a frequência respiratória

Em relação a intensidade do grito e ao comportamento realizado pelos leitões no momento das práticas realizadas, a ordem crescente das práticas com menores intensidades dos gritos emitidas por leitões foram a castração $(41,3 \mathrm{~dB})$, mossa australiana $(62,5 \mathrm{~dB})$ e desgaste dos dentes $(66,59)$. Para a intensidade máxima, a ordem crescente dos procedimentos foram diferentes da mínimas, com a castração (135,7 dB), desgaste de dentes $(99,1 \mathrm{~dB})$ e mossa australiana $(98,6 \mathrm{Db})(\mathrm{P}>0,01)$, respectivamente. Apenas no momento da prática de desgaste dos dentes a intensidade máxima apresentou correlação positiva com a intensidade mínima do grito $(P>0,01)$.

O comportamento de esquiva foi realizado durante as três práticas, possivelmente pela dor causada pelos instrumentos e pela contenção dos animais pelos manejadores. A permanência em inatividade e o comportamento de esquiva no momento da realização do desgaste dos dentes pelos leitões influenciou significativamente na intensidade mínima e máxima realizada pelos leitões $(P<0,05)$.

Os demais comportamentos realizados durante a prática de desgaste e todos os comportamentos realizados após as práticas de mossagem australiana e castração não influenciaram na intensidade mínima e máxima do grito emitido pelos leitões $(P>0,05)$. 
Nas práticas avaliadas, o comportamento positivo e outros não foram realizados pelos leitões. Avaliando as práticas em conjunto (desgaste do dente e mossa australiana), (desgaste e castração) e (mossa australiana e castração), apenas a mossa australiana e a castração correlacionadas apresentaram correlação positiva em relação a intensidade do grito do leitão no momento da realização do comportamento de esquiva.

\section{Discussão}

O comportamento dos leitões foi alterado após as práticas dolorosas, resultando em maior apresentação de ócio, maior exploração ambiental, com menor procura pelos tetos em relação a análise anterior aos procedimentos. Sentimentos negativos como frustação, medo, dor e solidão reduzem o bem-estar dos animais (DUNCAN, 1993). Segundo Furtado et al. (2007) o trauma da castração pode reduzir a atividade dos leitões trazendo alterações da mamada com diminuição do volume de leite ingerido, especialmente no período de formação da ordem da mamada. Ao sentir dor, o animal busca eliminá-la a partir de comportamentos e posturas agressivas ou estereotipadas (ANDRADE et al., 2007),

Os leitões, após as práticas realizadas apresentaram maior vocalização, decorrente, possivelmente, da dor causada pelo manejo, como o corte nas pontas das orelhas, pela incisão da castração e por possíveis lesões realizadas sem anestesia (Figura 1).

Figura 1 - Leitão após práticas de castração, desgaste de dentes e mossa australiana no segundo dia após o nascimento realizadas sem anestesia

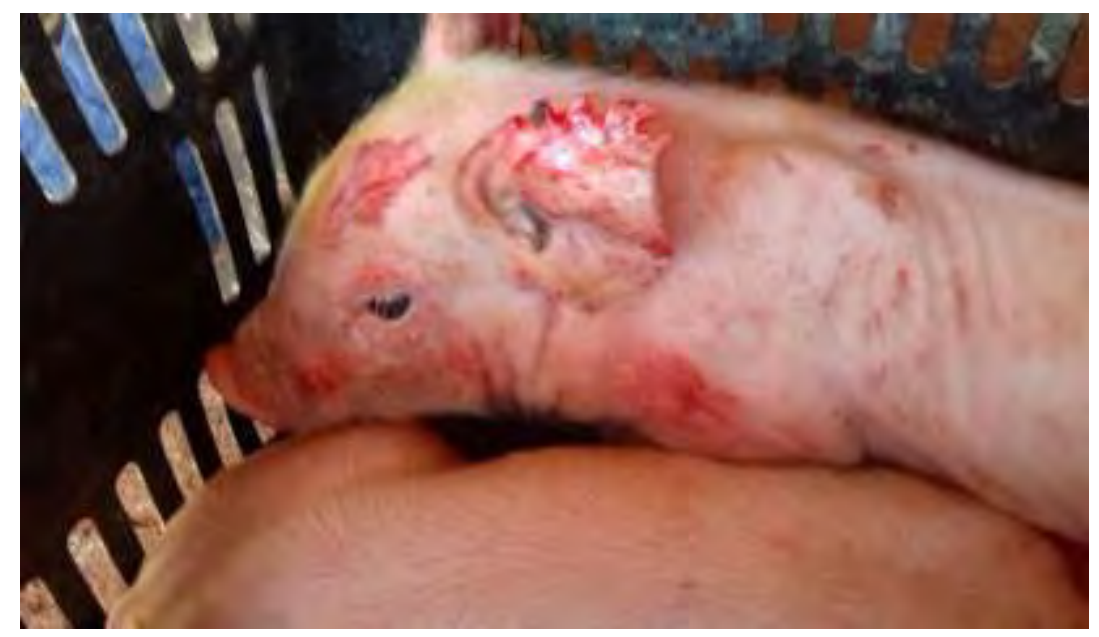

Fonte: Própria autoria.

O comportamento de ócio pelas porcas foi verificado em maior frequência antes da retirada dos leitões, devido provavelmente ao fato de que na fase de lactação as fêmeas tendem a permanecer nesta postura devido a amamentação. Em gaiolas, como neste estudo, porcas permanecem em ócio pela falta de mobilidade devido ao restrito espaço disponível, apresentando aumento de estereotipias, que são mecanismos compensatórios diante da 
privação comportamental, a partir de atividades repetitivas, sem função aparente (FRASER; BROOM, 1990).

Tolon et al. (2010) indicaram que acima de $85 \mathrm{~dB}$ de nível de pressão sonora, o animal fica impossibilitado de apresentar seu comportamento natural e os grunhidos, curtos ou longos, indicando situações de ameaças ou comportamentos exploratórios, bem de contato e excitação em grupo. Neste estudo foram encontradas frequências altas de vocalização, como 135, 7 dB para a castração, 99, 1 dB para o desgaste de dentes e 98,6 para a mossa australiana, que indica que houve aumento do estresse nos leitões com o decorrer das práticas e aumento da vocalização segue o aumento do nível da dor, decorrentes do tipo de contenção empregado, do procedimento utilizado e pela dor causada aos lactentes nos primeiros dias de nascido, indicando que vocalização pode ser considerada uma estimativa da não conformidade com as condições de bem-estar dos suínos (Manteuffel et al. (2002) e Weary et al. (1999). Corroborando com este resultado, Cordeiro et al. (2012), buscando estimar o nível de dor pela expressão vocal de suínos, avaliaram procedimentos de marcação, caudectomia e castração, em leitões na fase de maternidade, encontrando que a intensidade do som aumenta continuamente de normal $(70,41 \mathrm{~dB})$ para marcação $(77,64 \mathrm{~dB})$, depois para caudectomia $(88,31 \mathrm{~dB})$ e castração $(87,39 \mathrm{~dB})$, níveis abaixo dos encontrados por esta pesquisa, contudo apresentando efeitos negativos ao bem-estar dos suínos.

Leitões castrados sem anestesia apresentam um ruído com frequência e intensidade de pressão sonora diferente dos anestesiados, podendo ser indicador da intensidade da dor provocada pela prática (MARX et al., 2003). A castração sem anestesia, gera praticamente o dobro de gritos quando comparada a restrição, com redução da frequência dos gritos durante a dor, podendo indicar aumento da energia utilizada pelos animais (MARX et al., 2003). Para White et al. (1995) um acréscimo na frequência dos gritos indica, consecutivamente, aumento do estresse e redução do bem-estar animal.

Em relação ao tempo para realização das práticas, a castração apresentou maior tempo $(24,2 \mathrm{~s})$, seguido pelo desgaste de dentes $(16,0)$ e mossa australiana $(15,0)$, possivelmente atribuído ao tipo de contenção e sensibilidade empregada ao manejador. Segundo Leidig et al. (2009) procedimentos cirúrgicos como corte de dentes e cauda, podem perdurar de 20 a 70 segundos, e que em um tempo médio de 45 segundos, o gasto de energia, devido à dor ou a fome pode chegar até 342,09 kcal. Detalhe importante estudado por Dela Ricci et al. (2017) indicaram que velocidade de realização do desgaste de dentes e a experiência dos manejadores ao realizar praticas dolorosas com leitões recém nascidos influencia no número de lesões causadas nos animais, onde funcionários com maior treinamento geram menos lesões, contudo, em maior velocidade de realização, causam maior número de lesões de cavidade bucal dos animais. 
O aumento da frequência respiratória das fêmeas após o retorno dos leitões as baias, pode indicar estresse devido a expectativa de retorno dos lactentes e por ouvir vocalizações dos leitões durante as práticas. A frequência respiratória pode ser alterada intrinsicamente em razão de respostas à excitações, medo, exercícios físicos, estado fisiológico e produção leiteira (BACCARI Jr., 2001). Em conforto térmico os suínos apresentam valores de frequência respiratória para leitões ao nascimento de 40 a 50 movimentos por minuto, e para porcas em lactação de 30 a 40 (MUIRHEAD; ALEXANDER, 1997).

Ainda que aparentemente os lactentes se adaptem ao estresse causado pelas práticas comuns na suinocultura, métodos alternativos, como brincos, castração com anestesia e transferência de leitões com pesos semelhantes para evitar o desgaste ou corte dos dentes, podem apresentar vantagens em relação ao suporte e a produtividade dos leitões, permitindo a aceitação do procedimento de realização das partes envolvidas (MARCHANT-FORDE et al., 2009), além de garantir melhor bem-estar aos suínos.

Neste estudo observou-se que a utilização de métodos não- invasivos, para análise de estresse, como a análise de comportamento e vocalização são ferramentas importantes e eficientes pela maior facilidade de obtenção de dados, uma vez que não causam estresse aos animais e periculosidade aos manejadores durante a contenção, com avaliações em intervalos regulares ao longo do período investigado. A ausência de incomodo dessas técnicas, não geram aumento do glicocorticóides decorrentes da contenção, tornando-se uma forma de avaliação acurada de estresse (WASSER et al., 2000).

\section{$5 \quad$ Conclusão}

Após procedimentos dolorosos no segundo dia de nascido, são observadas alterações comportamentais e diminuição do bem-estar dos leitões e porcas. A utilização de análises de comportamento e vocalização se constituem como uma ferramenta simples, prática e nãoinvasiva para observação dessas alterações oriundas de desconforto emocional e fisiológico em que os suínos estão submetidos. 


\section{Referências}

ANDRADE, A.; PINTO, S. C.; OLIVEIRA, R. S. Animais de laboratório: criação e experimentação. Rio de Janeiro: FIOCRUZ, 2007.

BACCARI, J. Manejo ambiental da vaca leiteira em climas quentes. Londrina: Universidade Estadual de Londrina, 2011.

BATES, R. O. et al. The influence of canine teeth clipping on nursing and nursery pig performance. Journal of Swine Health and Production, Perry, v. 11, n. 2, p. 75-79, 2003.

BROOM, D. M.; MOLENTO, C. F. Bem-estar animal: conceitos e questões relacionadas Revisão. Archives of Veterinary Science, Curitiba, v. 9, p. 1-11, 2004.

CORDEIRO, A. F. D. S. et al. Medida de vocalização de suínos (Sus scrofa) como um indicador de gasto energético. Revista Brasileira de Engenharia de Biossistemas, Tupã, v. 2, p. 143-152, 2008.

DALLA COSTA, O. A. et al. Sistema alternativo de criação de suínos em cama sobreposta para agricultura familiar. Concórdia: Embrapa CNPSA, 2006. (Comunicado Técnico, 419). Disponível em:

$<$ https://www.infoteca.cnptia.embrapa.br/bitstream/doc/962451/1/DCOT419.pdf>. Acesso em: 20 ago. 2018.

DEL-CLARO, K. Comportamento animal: uma introdução à ecologia comportamental. Jundiaí: Livraria Conceito, 2004.

DUNCAN, I. J. H. Welfare is to do with what animals feel. Journal of Agricultural and Environmental Ethics, Dordrecht, v. 6, p. 8-14, 1993.

DÜPJAN, S. et al. Differential vocal responses to physical and mental stressors in domestic pigs. Applied Animal Behaviour Science, Amsterdam, v. 114, p. 105-115, 2008.

FERREIRA, R. A. et al. Redução do nível de proteína bruta e suplementação de aminoácidos em rações para suínos machos castrados mantidos em ambiente termoneutro dos 30 aos 60 kg. Revista Brasileira de Zootecnia, Viçosa, v. 34, n. 2, p. 548-556, 2005.

FRASER, D. The vocalization and other behaviour of growing pigs in an "open field" test. Applied Animal Ethology, Amsterdam, v. 1, p. 13-16, 1974.

FRASER, A. F.; BROOM, D. M. Farm animal behaviour and welfare. London: Balliere Tindall, 1990.

FRASER, D. Vocalizations of isolated piglets. I. Sources of variation and relationships among measures. Applied Animal Ethology, v.1, p. 387-394, 1975.

FURTADO, C. S. D. et al. Fatores não infecciosos que influenciam o desempenho de leitões lactentes. Acta Scientiae Veterinariae, Porto Alegre, v. 35, p. S47-S55, 2007. Suplemento.

HESSING, M. J. C. et al. Individual behavioural characteristics in pigs. Applied Animal Behaviour Science, Amsterdam, v. 37, p. 285-295, 1993.

KASANEN, S.; ALGERS, B. A note on the effects of additional sow gruntings on suckling behaviour in piglets. Applied Animal Behaviour Science, Amsterdam, v. 72, 93-101, 2002. 
LEIDIG, M. S. et al. Pain and discomfort in male piglets during surgical castration with and without local anesthesia as determined by vocalization and defence behaviour. Applied Animal Behaviour Science, Amsterdam, v. 116, p. 174-178, 2009.

MARCHANT-FORDE, M. R.; BRADSHAW, H. R.; BROOM, D. M. A note on the effect of gestation housing environment on approach test measures in gilts. Applied Animal Behaviour Science, Amsterdam, v. 80, p. 28-296, 2003.

MARCHANT-FORDE, J. N. et al. Postnatal piglet husbandry practices and well-being: The effects of alternative techniques delivered separately. Journal Animal Science, Cary, v. 87, p. 1479-1492, 2009.

MARX, G. et al. Analysis of pain-related vocalization in young pigs. Journal of Sound and Vibration, London, v. 266, p. 687-698, 2003.

MANTEUFFEL, G.; SCHON, P. C. Measuring pig welfare by automatic monitoring of stress calls. Bornimer: Agrartechnische Berichte Editor, 2002.

MANTEUFFEL, G.; PUPPE, B.; SCHÖN, P. C. Vocalization of farm animals as a measure of welfare. Applied Animal Behaviour Science, Amsterdam, v. 88, p.163-182, 2004.

MEINDL, M.; PAUL, E. S. Consciousness, emotion and animal welfare: insights from cognitive science. Animal Welfare, St Albans, v. 13, p. 17-26, 2004.

MOI, M. et al. Vocalização como indicativo do bem-estar de suínos submetidos a situações de estresse. Arquivo Brasileiro Medicina Veterinaria Zootecnia, Belo Horizonte, v. 67, p. 837-845, 2005.

MUIRHEAD, M. R.; ALEXANDER, T. J. L. Managing and treating disease in the farrowing and suckling period. In: MUIRHEAD, M. R.; ALEXANDER, T. J. L. (Ed.). Managing pig health: a reference for the farm. Sheffield: Enterprises, 1997. cap. 2, p. 227-282.

PEREIRA, J. R. G. Métodos não-invasivos para análises hormonais aplicadas aos estudos de ecologia e etologia. Revista Brasileira de Zootecnia, Viçosa, v. 36, p. 71-76, 2007.

POLETTO, R. Bem-estar animal. Suíno.com, Tangará, 5 abr. 2010. (Série especial bemestar animal por Rosangela Poletto). Disponível em: <http://tinyurl.com/4t6z4bk>. Acesso em: 03 jul. 2018.

PUPPE, B.; SCHÖN, P. C.; TUCHSCHERER, A. Castration-induced vocalization in domestic piglets, Sus scrofa: Complex and specific alternations of the vocal quality. Applied Animal Behaviour Science, Amsterdam, v. 95, p. 67-78, 2005.

SARUBBI, J. Bem-estar dos animais e uso racional de energia elétrica em sistemas de aquecimento para leitões desmamados. $2009.190 \mathrm{f}$. Tese (Doutorado) - Faculdade de Engenharia Agrícola, Universidade Estadual de Campinas, Campinas, 2009.

WASSER, S. K. et al. A generalized fecal glucocorticoid assay for use in a diverse array of nondomestic mammalian and avian species. General and Comparative Endocrinology, Maryland Heights, v. 120, p. 260-275, 2000.

WEARY, D. M.; ROSS, S.; FRASER, D. Vocalizations by isolated piglets: a reliable indicator of piglet need directed towards the sow. Applied Animal Behaviour Science, Amsterdam, v. 53, n. 4, p. 249-257, 1997. 
WEARY, D. M.; APPLEBY, M. C.; FRASER, D. Responses of piglets to early separation from the sow. Applied Animal Behaviour Science, Amsterdam, v. 63, p. 289-300, 1999.

WHITE, R. G. et al. Vocalization and physiological response of pigs during castration with or without a local anaesthetic. Journal of Animal Science, Champaign, v. 73, p. 381-386, 1995.

ZANELLA, A. J. Indicadores fisiológicos e comportamentais do bem-estar animal. A Hora Veterinária, Porto Alegre, v. 14, p. 47-52, 1995. 


\section{APÊNDICE B - EFEITO DA VELOCIDADE DE MANEJO EM PROCEDIMENTOS ROTINEIROS NA SUINOCULTURA SOBRE VOCALIZAÇÂO E COMPORTAMENTO DE LEITÕES ${ }^{3}$}

\section{Resumo}

Vocalização e comportamento são métodos não invasivos de análise de bem-estar animal. O objetivo deste estudo foi avaliar o bem-estar de leitões durante as práticas de mossa australiana, desgaste de dentes e castração, a partir de vocalizações e aspectos comportamentais dos suínos. Para tal, foram utilizados 281 leitões, com aferições da intensidade máxima e mínima do ruído emitido e o tempo de realização das práticas. 0 comportamento dos leitões foi obtido de acordo com a atividade desempenhada durante o manejo e contenção. Para análise comportamental foi utilizado um etograma e para a análise de vocalização dois decibelímetros. A comparação de médias foi realizada pelo teste-T a 5\%. A castração foi a prática com maior média de tempo de realização, seguida pelo desgaste de dentes e mossa australiana. Os maiores valores de média de intensidade mínima e máxima foram encontrados para a castração de machos, no processo lento. Observou-se que o sexo não influenciou no tempo em que a mossa e o desgaste de dentes foram realizados, mas durante os mesmos o comportamento de esquiva foi o mais observado, com baixa frequência na castração. Portanto, pode-se concluir que os procedimentos ocasionaram dor, caracterizada por demonstrações vocais e de comportamento negativo.

\section{Introdução}

O mercado consumidor de produtos de origem animal tem direcionado maior atenção à ciência do bem-estar, buscando maior entendimento e transparência nas formas de produção, rejeitando práticas de manejo e alojamento que agridam a fisiologia e etologia dos animais (POLETTO, 2009), como mossagem australiana, caudectomia, corte ou desgaste de dentes e castração sem anestesia.

A análise do bem-estar animal pode ser efetuada a partir de critérios comportamentais, a partir da observação de estereotipias; alterações fisiológicas, como o aumento das concentrações de cortisol, da frequência cardíaca e respiratória, respostas do sistema

\footnotetext{
${ }^{3}$ Submetido a Revista Investigación Agraria
} 
imunológico e a sanidade; e ambientais, com aumento dos níveis de ruídos, da temperatura e umidade do ar (BAPTISTA et al., 2011; BROOM; MOLENTO, 2004).

A reavaliação das práticas dentro da produção animal, por meio de análises das necessidades e estados físicos e emocionais, identificação de problemas técnicos que causem dor e sofrimento e a recomendação de alterações de modelos e procedimentos que almejem respeito e ética com os animais é a principal base para o surgimento e comprometimento da ciência do bem-estar animal (RAMOS, 2006).

Entre os métodos de mensurar o bem-estar animal, a vocalização tem-se mostrado eficiente (MANTEUFFEL et al., 2004; MARX et al., 2003; WEARY; FRASER, 1997), por ser um método não invasivo, uma vez que não interfere na expressão natural do comportamento, auxiliando na interpretação de reações comportamentais dos animais (DUNKAN, 2005).

A vocalização é utilizada como método para se expressar sendo notada e utilizada como critério desde as primeiras semanas de nascido (HESSING et al., 1993). Essa possui características individuais, sendo um importante método de comunicação entre indivíduos da mesma espécie (GRANDIN, 1998). Quando emitidas, em situações de estresse, as vocalizações atuam como indicador de bem-estar e como uma estimativa instantânea do estado emocional dos animais (DÜPJAN et al., 2008).

Suínos apresentam vasto repertório de vocalizações que permitem a atração de parceiros, advertir a presença ou intimidar possíveis agressores. O estudo dos sons emitidos por suínos tem sido estudado em diferentes idades, com identificação de situações de comunicação e diestresse (KASANEN; ALGERS 2002), de conflitos (MARCHANT et al., 2001; TALLING et al.; 1998; WEARY; FRASER, 1995), relacionando tempo de expressão e frequência de realização. Vocalizações de baixa tonalidade, como grunhidos, são utilizadas para realização de contatos sociais, com membros do mesmo grupo, à medida que, altas tonalidades, com semelhanças a gritos, são notadamente mais utilizadas em estados de excitação aparente (SCHRADER; TODT, 1998).

De acordo com a importância de se reavaliar os procedimentos realizados com suínos em seus primeiros dias de nascido, este estudo objetivou analisar o bem-estar de leitões durante as práticas de mossa australiana, desgaste de dentes e castração, sem anestesia, a partir de estimativas de vocalizações com análises comportamentais dos suínos e dos manejadores.

\section{Material e Métodos}

O estudo foi conduzido nas instalações de maternidade do Setor de Suinocultura da Prefeitura, na Universidade de São Paulo, Campus Fernando Costa, em Pirassununga, estado de São Paulo. O local encontra-se em altitude de 340 metros, latitude sul de $21^{\circ} 80^{\prime} 00^{\prime \prime}$ 
e longitude oeste de $47^{\circ} 25^{\prime} 42 "$, clima Cwa com temperaturas anuais mínimas médias de 13 e máximas de $31^{\circ} \mathrm{C}$, segundo Koppen (2011).

Foram utilizadas 26 fêmeas, Landrace x Large White, 281 leitões, sendo 154 fêmeas e 127 machos, em sistema de confinamento com celas parideiras e acesso de escamoteadores pelos leitões. O manejo nutricional era realizado de manhã e à tarde para fêmeas e leitões, com $7 \mathrm{~kg}$ ao dia para fêmeas e progressivo para os leitões, iniciando com 200 gramas na primeira semana e $500 \mathrm{~g}$ na semana do desmame.

As práticas avaliadas foram mossa australiana (1), desgaste dos dentes (2) e castração (3). Para isso, os leitões foram retirados em caixas plásticas das baias com gaiolas, local onde se somam cinco áreas, das quais há uma distância da sala de manejo de 1 metro da primeira até 25 metros da última, onde foram realizados os procedimentos.

Para a mossa australiana (1), utilizou-se um alicate marcador de orelha de $30 \mathrm{~cm} \mathrm{em}$ forma de $U$, na qual a cavidade bucal dos animais foi pressionada pela mão do manejador, mantendo-se livres as duas orelhas, fazendo com que o animal permaneça imobilizado. Para o desgaste dos dentes (2), o leitão foi contido pela cabeça, onde o dedo indicador foi inserido na cavidade bucal, junto a gengiva, afastando os lábios dos dentes que serão raspados. Foi utilizado um desbastador de dentes da marca Dremel. Para o manejo da castração (3) o animal foi delimitado em um pequeno espaço, com os membros posteriores voltados para cima, fazendo com que a bolsa escrotal fique livre para o manejo. A técnica de castração utilizada pela granja foi via escrotal, sem aplicação de anestesia ou analgesia, na qual uma incisão de aproximadamente $2 \mathrm{~cm}$ expõe os testículos, para remoção por corte. O corte foi realizado a partir de um bisturi com aplicação de antissépticos locais para cicatrização do ferimento (PRUNIER et al., 2006; SOBESTIANSKY et al., 2003).

As práticas com os leitões ocorreram no segundo dia após o nascimento e foram realizadas por técnicos da granja seguindo o protocolo. Nesse estudo, apenas animais sadios participaram dos procedimentos. Aqueles que se apresentavam enfermos ou muito pequenos foram retirados do estudo e permaneceram em quarentena até a melhora do quadro.

Durante a realização dos procedimentos foram aferidas a intensidade máxima e mínima em decibéis $(\mathrm{dB})$ do ruído emitido pelos leitões a partir de um decibelímetro digital dataloggers (MINIPA, MSL1352C) posicionado a distância de, no máximo, $20 \mathrm{~cm}$ da cavidade bucal dos leitões (Figura 2).

O tempo de realização das práticas foi mensurado individualmente a partir de um cronômetro digital, utilizado do início até a finalização da prática. A velocidade de realização foi classificada como rápida, normal e lenta (Tabela 3).

O comportamento dos leitões frente às três práticas foi realizado de acordo com o desenvolvimento dos leitões durante o manejo da contenção dentro do tempo obtido. 
Confeccionou-se um etograma, com horário, prática executada, manejador responsável e comportamentos agressivos, de esquiva, positivo, nenhum e outros dos leitões (Quadro 1).

Figura 2 - Contenção de leitão para a prática de desgaste de dentes com obtenção de intensidade mínima e máxima de ruído emitido com auxílio do decibelímetro

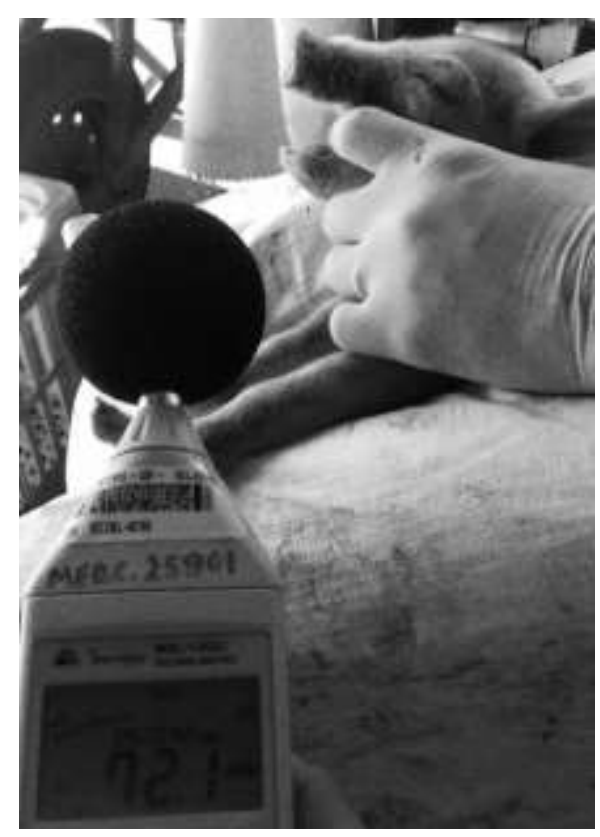

Fonte: Própria autoria.

Tabela 3 - Classificação dos intervalos de tempos utilizados para mensurar a velocidade do manejo durante as práticas no segundo dia após o nascimento dos leitões

\begin{tabular}{cccc}
\hline \multirow{2}{*}{ Procedimento } & \multicolumn{3}{c}{ Velocidade (s) } \\
\cline { 2 - 4 } & Rápido & Normal & Lento \\
\hline Mossa Australiana & $<10,1$ & 10,2 a 18,7 & $>18,8$ \\
\hline Desgaste de dentes & $<10,3$ & 10,4 a 20,8 & $>20,9$ \\
\hline Castração & $<13,2$ & 13,3 a 30,9 & $>31$ \\
\hline
\end{tabular}

Fonte: Própria autoria.

Quadro 1 - Etograma utilizado para avaliação do comportamento e intensidade da vocalização dos leitões durante a realização das práticas de manejo

\begin{tabular}{|c|c|}
\hline Comportamento & Descrição \\
\hline Agressivo & Tentativa de morder ou avançar no manejador \\
\hline Esquivar & Tentativa de fuga da forma de contenção durante o manejo \\
\hline Positivo & Tentativa de afago com o manejador \\
\hline Nenhum & Nenhuma atividade, permanecer imóvel e sem vocalizar \\
\hline Outro & Qualquer outra atividade que não esteja descrita nos comportamentos anteriores \\
\hline
\end{tabular}

Fonte: Própria autoria. 
Foi realizada correlação do sexo, peso e a velocidade de realização das práticas e o efeito entre tempo de realização dos leitões e intensidade do grito emitido pelos lactentes pelo SAS (2017). A comparação de médias foi realizada pelo teste-T e PDIFF.

\section{$3 \quad$ Resultados}

A média de tempo para realização das práticas foi maior para a castração (3), seguida pelo desgaste dos dentes (2) e pela mossa australiana (1), com médias de 24,21, 16,03 e 15,05 segundos, respectivamente $(P<0,01)$. A prática de castração apresentou maiores valores de tempo para a realização nas três classificações de velocidade (lenta, normal e rápida), com 56, 30 e 13 segundos, apresentando também as maiores médias mínimas, nas três velocidades sendo 31, 13,8 e 8 segundos (Figura 3).

Figura 3 - Tempo máximo, médio e mínimo de realização das práticas de mossa australiana, desgaste de dentes e castração de leitões

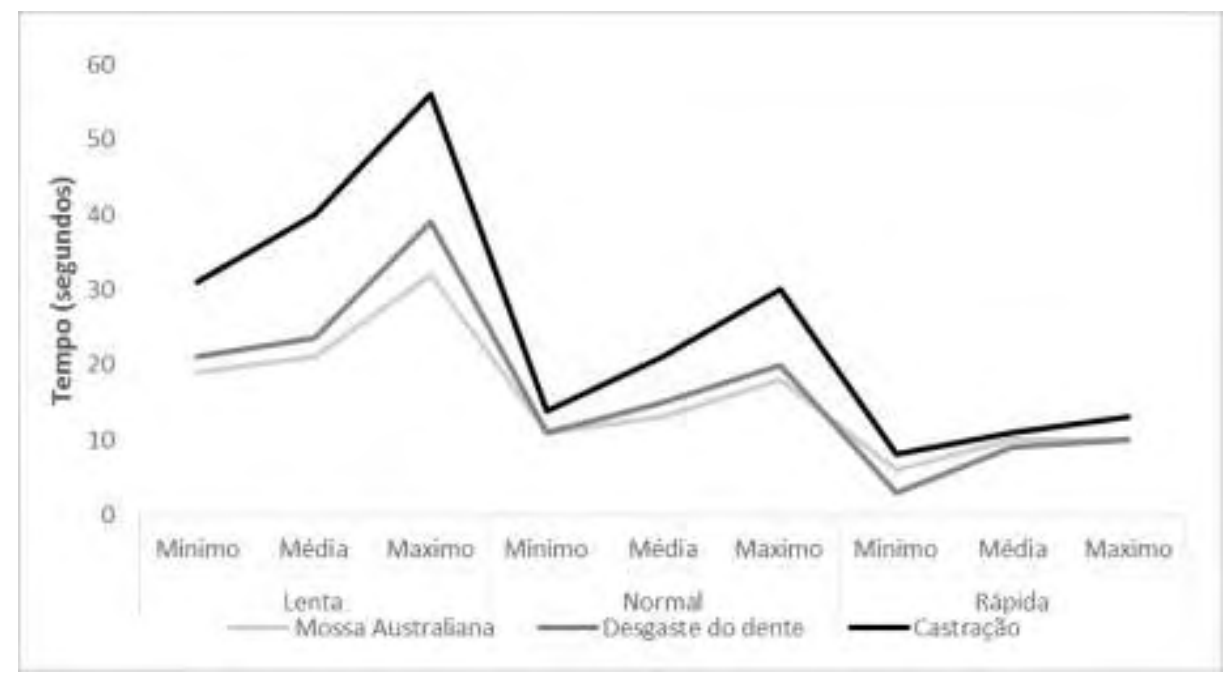

Fonte: Própria autoria.

A intensidade mínima do grito durante as práticas com menor e maior frequência foram obtidas na classificação lenta e rápida da castração com 58,8 e 103,0 dB (Tabela 2). A velocidade classificada como rápida, apresentou, para todas as práticas valores acima dos estabelecidos como normais $(70,41 \mathrm{~dB})$.

No entanto, a velocidade lenta, apresenta problemas relacionados a redução do conforto dos animais e consecutivo aumento da vocalização mínima e máxima, devido, principalmente, pelo método de contenção empregado para a realização dos três procedimentos. A prática classificada normal apresentou valores de intensidade mínima abaixo dos definidos como normais, no entanto apresentou níveis elevados para a intensidade 
máxima, indicando que todas as velocidades classificadas apresentaram alterações e possível dor e desconforto nos leitões (Tabela 4).

Tabela 4 - Níveis de intensidade mínima e máxima em decibéis de acordo com a classificação de velocidade em segundos para procedimentos de mossa australiana, desgaste de dentes e castração de leitões

\begin{tabular}{llll}
\hline Procedimento & $\begin{array}{c}\text { Velocidade } \\
\text { (Segundos) }\end{array}$ & $\begin{array}{c}\text { Intensidade mínima } \\
\text { (Decibéis) }\end{array}$ & $\begin{array}{c}\text { Intensidade máxima } \\
\text { (Decibéis) }\end{array}$ \\
\hline \multirow{3}{*}{ Mossa Australiana } & Lenta & $62,09 \pm 3.064 \mathrm{Ab}$ & $93,68 \pm 5.172 \mathrm{Bb}$ \\
& Normal & $66,94 \pm 1.479 \mathrm{Aa}$ & $99,73 \pm 2.497 \mathrm{Ba}$ \\
& Rápida & $69,50 \pm 3.026 \mathrm{Aa}$ & $101,79 \pm 5.108 \mathrm{Ba}$ \\
\hline \multirow{2}{*}{ Desgaste de dentes } & Lenta & $59,69 \pm 3.234 \mathrm{Ab}$ & $100,84 \pm 5.460 \mathrm{Ba}$ \\
& Normal & $60,65 \pm 1.454 \mathrm{Ab}$ & $100,15 \pm 2.460 \mathrm{Ba}$ \\
\hline Castração & Rápida & $71,51 \pm 3.160 \mathrm{Aa}$ & $90,02 \pm 5.334 \mathrm{Bb}$ \\
& Lenta & $58,84 \pm 5.157 \mathrm{Ab}$ & $103,06 \pm 8.706 \mathrm{Ba}$ \\
& Normal & $62,12 \pm 2.170 \mathrm{Ac}$ & $101,31 \pm 3.663 \mathrm{Bb}$ \\
& Rápida & $65,68 \pm 5.157 \mathrm{Aa}$ & $96,89 \pm 8.709 \mathrm{Bc}$ \\
\hline
\end{tabular}

Fonte: Própria autoria.

As médias de intensidades mínimas encontradas para as fêmeas, nas duas práticas, foi de $63,75 \mathrm{~dB}$ e para os machos de 64,47 dB (P>0,01). Em relação às intensidades máximas, para as fêmeas foram encontrados valores de $97,72 \mathrm{~dB}$ e de $99,50 \mathrm{~dB}$ para machos $(P>0,01)$.

Durante o manejo de mossa, desgaste de dentes e castração, comprovadamente os leitões esquivaram-se dos objetos e manejadores, sendo o comportamento mais expresso pelos lactentes $(\mathrm{P}<0,01)$. Notou-se que ou os animais estavam tentando a fuga ou permaneciam parados, sem esboçar nenhuma atividade corporal e vocal $(P<0,01)$.

O comportamento agressivo realizado em baixa frequência $(0,3 \%)$ nas práticas 1 e 2 , não foi apresentado por leitões na prática de castração, explicado pela forma com que os leitões são contidos pelos manejadores, gerando imobilização (Figura 3). O comportamento positivo e outros não foram observados nas três práticas de manejo.

O comportamento de esquiva e nenhum (permanecer em inatividade) durante a realização do desgaste dos dentes dos leitões influenciou significativamente a intensidade mínima e máxima dos gritos $(\mathrm{P}<0,05)$.

Apesar das fêmeas terem apresentado peso médio inferior ao dos machos, com 1,674 e $1,791 \mathrm{~kg}$, respectivamente, o peso dos leitões não influenciou na intensidade máxima e mínima do grito emitido durante a realização das três práticas.

O sexo dos leitões não influenciou no tempo em que os procedimentos foram realizados. A média de tempo de realização total das duas práticas para as fêmeas foi de 
18,33 segundos e para os machos de 18,54 segundos ( $P>0,01)$. O sexo dos animais e prática realizada com leitões não influiu na apresentação de comportamentos agressivos no momento do manejo $(P>0,01)$.

\section{Discussão}

Nesse estudo, os leitões foram retirados das gaiolas parideiras e encaminhados à sala de manejo. A localização da sala de manejo estava próxima às baias onde foram alojadas as matrizes e de acordo com a literatura, pela proximidade, os leitões foram capazes de ouvir aos chamados da mãe, devido à separação (WEARY et al., 1999) e por isso puderam reagir executando um tipo de chamado especifico, devido ao estresse. Suínos podem detectar sons na faixa de 20 a $20000 \mathrm{~Hz}$, com deslocamento de ultrassom, e uma faixa de detecção de frequência razoável de 42 Hertz a 40,5 quilohertz com sensibilidade de $250 \mathrm{~Hz}$ a $16 \mathrm{kHz}$ (HEFFNER; HEFFNER, 1990). Puppe et al. (2003), indicaram que leitões de diferentes leitegadas, ao ouvirem a gravação da vocalização da sua mãe, escolhiam permanecer mais próximos à fonte de vocalização da sua mãe em relação a de outras porcas.

Em relação a duração das práticas, a maior média de tempo para realização encontrada foi da castração (24,21s), seguida pelo desgaste dos dentes $(16,03 \mathrm{~s})$ e pela mossa australiana $(15,05 s) \quad(P<0,01)$, com diferenças no tempo devido ao método de contenção empregado e ao treinamento do manejador para a realização. Segundo Leidig et al. (2009) procedimentos cirúrgicos como corte de dentes e cauda, podem perdurar de 20 a 70 segundos, e que em um tempo médio de 45 segundos, o investimento em energia, devido à dor ou a fome por exemplo, pode ser de até 342,09 kcal. Grunhidos individuais em suínos podem durar, em média, de 0,13 a 2 segundos, considerando a média de 1 segundo por expressão vocal, como medo, com um gasto energético especifico para diferentes expressões, variando de 0,056 a 0,463 kcal, o que acarreta perdas produtivas importantes ao longo do sistema produtivo (MARCHANT et al., 2001). A dor ou muita dor pode gerar expressões de 3,7 vezes mais tempo de duração do que as relacionadas as condições normais, como grunhidos isolados e simples que estão associados a comportamentos exploratórios dos suínos (CORDEIRO et al., 2008; KASANEN; ALGERS, 2002).

A velocidade com que os procedimentos foram realizados causaram lesões e dor nos leitões. Na prática de castração, a velocidade lenta apresentou maiores índices de gritos, possivelmente pela forma de contenção dos animais, que de cabeça para baixo, tendem em conjunto com a prática, exercerem maiores índices de gritos. Para o desgaste dos dentes a prática lenta apresentou maiores índices de intensidade do grupo, sendo estatisticamente parecida com a velocidade moderada $(P>0,05)$. Neste caso o método de contenção, assim como o incomodo de inserir o aparelho na cavidade oral do animal pode ser responsável pela intensidade elevada. Maior tempo na prática trouxe mais incomodo aos animais. A mossa 
australiana apresentou maiores intensidades do grito para a velocidade rápida e uma explicação coerente pode estar relacionada ao número de lesões causadas pelo procedimentos, pelos de vasos sanguíneos cessados e a quantidade de sangue exposta. Dela Ricci et al. (2017) avaliando a velocidade de realização do desgaste de dentes e a experiência dos manejadores ao realizar o manejo encontrou que o manejador com maior experiência causa menos lesões mas que em maior velocidade, gera maior número de lesões de cavidade bucal dos animais.

As intensidades de vocalização encontradas neste estudo foram consideradas altas, em referência ao que já está proposto pela literatura. De acordo com o estudo realizado por Cordeiro et al. (2012), o nível de dor pode ser mensurado pela expressão vocal de suínos, onde pela avaliação de procedimentos de mossa australiana, caudectomia e castração, em leitões na fase de maternidade, encontraram que a intensidade do som aumenta continuamente de normal $(70,41 \mathrm{~dB})$ para marcação $(77,64 \mathrm{~dB})$, depois para caudectomia $(88,31 \mathrm{~dB})$ e castração $(87,39 \mathrm{~dB})$, indicando que o aumento da vocalização do suíno segue o aumento do nível de dor. Suínos submetidos a estresse diversos, mesmo na ausência de dor e dependendo do estímulo, duração e grau do estresse, podem mudar de maneira diferente, intensidade do sinal das suas expressões vocais (MOI et al., 2015).

O sexo dos leitões não influenciou no tempo que os manejadores levaram para realizar as práticas, assim como na apresentação de comportamentos agressivos e uma provável explicação pode estar relacionada a igualdade hormonal dos animais nesta idade e peso ao nascer que permite uma contenção imobilizadora dos animais. Atesta-se a necessidade de dois manejadores para a realização das práticas, o que normalmente não é obedecido em granjas suinícolas.

Neste estudo, ao sentir dor, o animal buscou eliminá-la a partir de posturas ou comportamentos, com a apresentação de esquivas permanentes durante os procedimentos. Não foram observados comportamentos positivos em relação ao momento do manejo, indicando que o momento das práticas apresenta-se cmo um evento traumático para os suínos. Segundo BOISSY et al. (2007) a manifestação de comportamentos específicos se estabelece como indicativo de desconforto ou frustração dos animais, geralmente pela privação de estímulos ambientais ou por circunstâncias diferentes das habituais, como o manejo de contenção. Caso não seja possível que o animal se esquive ou fuja da dor causada, o animal se frustra, inicia-se respostas de má adaptação, gerando e permanecendo em estresse (ANDRADE et al., 2002). 


\section{Conclusão}

Diante dos resultados obtidos pôde-se concluir que procedimentos como mossa australiana, desgaste de dentes e castração são métodos que ocasionam dor, caracterizada por demonstrações vocais e de comportamento, além do prejuízo ao bem-estar integral dos suínos na maternidade. Extinguir tais práticas requer treinamento de pessoal e conhecimento técnico sobre novos métodos de marcação, de eliminação de problemas com a mamada e sabor na carne. Priorizar o bem-estar animal, diante às necessidades econômicas, tornar-seá, em breve, pré-requisito para consumo de carne, levando os meios produtivos a se adaptarem às novas vertentes estipuladas. 


\section{Referências}

ANDRADE, A.; PINTO, S. C.; OLIVEIRA, R. S. Animais de laboratório: criação e experimentação. Rio de Janeiro: FIOCRUZ, 2002.

BAPTISTA, R. I. A. A.; BERTANI, G. R.; BARBOSA, C. N. Indicadores do bem-estar em suínos. Ciência Rural, Santa Maria, v. 41, n. 10, p. 1823-1830, 2011.

BOISSY, A. et al. Assessment of positive emotions in animals to improve their welfare. Physiology \& Behavior, Philadelphia, v. 92, p. 375-397, 2007.

BROOM, D. M.; MOLENTO, C. F. M. Bem-estar animal: conceitos e questões relacionadas Revisão. Archives of Veterinary Science, Curitiba, v. 9, p.1-11, 2004.

CORDEIRO, A. F. D. S. et al. Medida de vocalização de suínos (Sus scrofa) como um indicador de gasto energético. Revista Brasileira de Engenharia de Biossistemas, Tupã, v. 2 , p. 143-152, 2008.

CORDEIRO, A. F. S. et al. Efficiency of distinct data mining algorithms for classifying stress level in piglets from their vocalization. Engenharia Agrícola, Jaboticabal, v. 32, p. 208-216, 2012.

DUNKAN, I. J. H. Science-based assessment of animal welfare: farm animals. Revue Scientifique et Technique / Office International des Épizooties, Paris, v. 24, p. 483-492, 2005.

DÜPJAN, S.; SCHÖN, P. PUPPE, B. Differential vocal responses to physical and mental stressors in domestic pigs (Sus scrofa). Applied Animal Behaviour Science, Amsterdam, v. 114, p.105-115, 2008.

GRANDIN, T. The feasibility of using vocalization scoring as an indicator of poor welfare during slaughter. Applied Animal Behaviour Science, Amsterdam, v. 56, p. 121-8, 1998.

HESSING, M. J. C. et al. Individual behavioural characteristics in pigs. Applied Animal Behaviour Science, Amsterdam, v. 37, p. 285-295, 1993.

KASANEN, S.; ALGERS B. A note on the effects of additional sow gruntings on suckling behaviour in piglets. Applied Animal Behaviour Science, Amsterdam, v. 72, p. 93-101, 2002.

KOPPEN. Clima dos Municípios Paulistas. 2018. Informações sobre o Clima- Campinas, São Paulo. Disponível em:<http://www.cpa.unicamp.br/outras-informacoes/clima-dosmunicipios-paulistas.html>. Acesso em: 20 ago. 2018.

LEIDIG, M. S.; HERTRAMPF, B.; FAILING, K. Pain and discomfort in male piglets during surgical castration with and without local anesthesia as determined by vocalization and defence behaviour. Applied Animal Behaviour Science, Amsterdam, v. 116, p. 174-178, 2009.

LEWIS, N. J. Frustration of goal-directed behaviour in swine. Applied Animal Behaviour Science, Amsterdam, v. 64, p. 19-29, 1999.

MANTEUFFEL, G.; PUPPE, B.; SCHÖN, P. C. Vocalization of animals as a measure of welfare. Applied Animal Behaviour Science, Amsterdam, v. 88, p. 163-182, 2004. 
MARCHANT, J. N.; WHITTAKERB, X.; BROOM, D. M. Vocalisations of the adult female domestic pig during a standard human approach test and their relationships with behavioural and heart rate measures. Applied Animal Behaviour Science, Amsterdam, v. 72, p. 23-39, 2001.

MARX, G.; HORN, T.; THIELEBEIN, J. et al. Analysis of pain related vocalization in young pigs. Journal of Sound and Vibration, London, v. 266, p. 687-698, 2003.

MOI, M. et al. Vocalização como indicativo do bem-estar de suínos submetidos a situações de estresse. Arquivo Brasileiro de Medicina Veterinária e Zootecnia, Belo Horizonte, v. 67, p. 837-845, 2015.

POLETTO, R. Bem-estar animal. Suíno.com, Tangará, 5 abr. 2010. (Série especial bemestar animal por Rosangela Poletto). Disponível em: <http://tinyurl.com/4t6z4bk>. Acesso em: 03 jul. 2018.

PRUNIER, A. et al. A review of the welfare consequences of surgical castration in piglets and evaluation of non-surgical methods. Animal Welfare, St Albans, v. 15, p. 277-289, 2006.

PUPPE, B. et al. The influence of domestic piglets (Sus scrofa) age and test experience on the preference for the replayed maternal nursing vocalization in a modified open- field test. Acta Ethologica, Heidelberg, v. 5, p. 123-129, 2003.

RAMOS, J. B. Bem estar animal: a ciência de respeito aos animais. Informativo do Instituto Ecológico Aqualung, Rio de Janeiro, v. 12, n. 68, p. 4-5, 2006.

SCHRADER, L.; TODT, D. Vocal quality is correlated with levels of stress hormones in domestic pigs. Ethology, Berlin, v. 104, p. 859-876, 1998.

SOBESTIANSKY, J. et al. Suinocultura intensiva: considerações sobre sistema imune e utilização de vacinas. Goiânia: s.n., 2003.

TALLING, J. C. et al. The acoustic environment of the domestic pig. Journal of Agricultural Engineering Research, London, v. 71, p. 1-12, 1998.

WEARY, D. M.; APPLEBY, M. C.; FRASER, D. Responses of piglets to early separation from the sow. Applied Animal Behaviour Science, Amsterdam, v. 63, p. 289-300, 1999.

WEARY, D. M.; FRASER, D. Calling by domestic piglets: reliable signals of need. Animal Behaviour, London, v. 50, p. 1047-1055, 1995.

WEARY, D. M.; FRASER, D. Vocal response of piglet to weaning: effect of piglet age. Applied Animal Behaviour Science, Amsterdam, v. 54, p. 153-160, 1997. 